\title{
Towards the development of a chemical lure to improve the management of invading rat populations
}

By

Grace Laura Paske

A thesis submitted to the Victoria University of Wellington in fulfillment of the requirements for the degree of Masters of Biomedical Science

Victoria University of Wellington

2013 


\section{Acknowledgements}

First, and most importantly, I would like to thank my supervisors; Ken McNatty, Wayne Linklater, Rob Keyzers, and Doug Eckery. The support and guidance you have all given me over the past few years have been invaluable. Special thanks to Ken; I guarantee without your help in the last few months, I wouldn't have a complete thesis.

Thanks goes to Adrian Bibby for all your help in the lab, and answering endless questions about almost everything. Christine and Jono, thank you for sharing your vast proteomics knowledge with me, being great friends, and Christine for being so patient with me, even when it got to the point you answered your office phone with "Hello, Grace".

My friends - thank you. I am lucky enough to say I have too many to list here, but you all know who you are. You have all been so amazing and supportive, and aided in some very fun times, without which I don't think I would have any sanity left.

A huge thank you to my family, especially Holly and Luca, for everything. Luke, thank you for always believing I could do it, and encouraging me all the way.

Mum and Dad, I can never thank you enough for the last few years, your food, your money and your love. You have made this possible. 


\section{Abstract}

Introduced species, such as Rattus norvegicus and Rattus rattus, have contributed to the extinction of many native animals and plants in New Zealand (NZ). Current strategies exist to monitor, manage and eradicate pest species. However, these haven't always been completely successful and tools to detect small or invading densities remain to be developed. One possible new method to address this problem is the application of chemical attractants (lures). Recently, a major urinary protein (MUP) has been shown in male mice to act as a sexual attractant. MUPs modulate the release of volatile attractants and have potential to act as attractants themselves. Our aim was to determine if a similar MUP(s) and associated volatiles are present in the urine of rats, with the prospect of creating a chemical lure to use in rat detection and eradication. Using Gas Chromatography/Mass Spectrometry, potential volatiles in rat urine have been identified. Analysis of rat urine by gel electrophoresis has shown MUPs present in both sexes. A $22.4 \mathrm{kDa}$ MUP in Rattus norvegicus has been synthesised and expressed in E.coli using recombinant DNA technology. Preliminary steps have been made towards the production of a MUP based on ship rat DNA sequence. Future behavioral trials are needed to investigate whether the synthesised protein, in the presence or absence of the urinary-derived volatiles, is a sexual attractant. 


\section{TABLE OF CONTENTS}

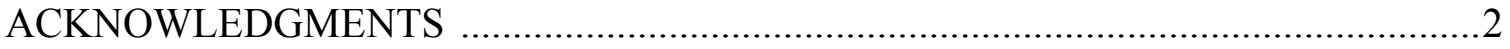

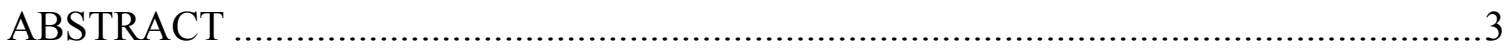

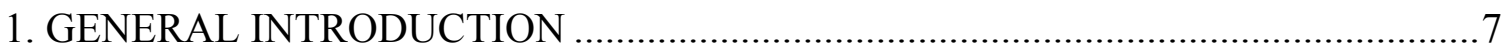

1.1 IMPACT OF PESTS IN THE NEW ZEALAND LANDSCAPE .................................................

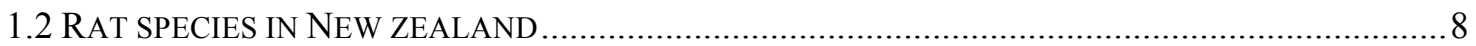

1.3 EFFORTS FOR PEST ERADICATION

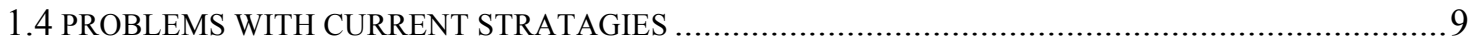

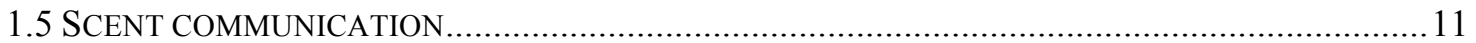

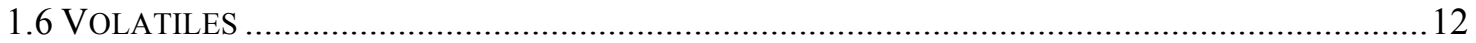

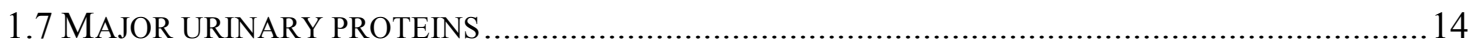

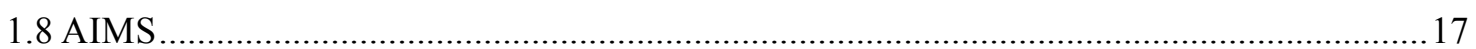

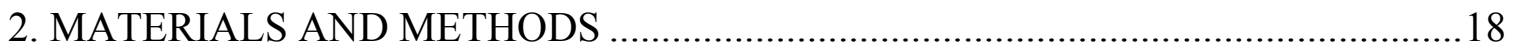

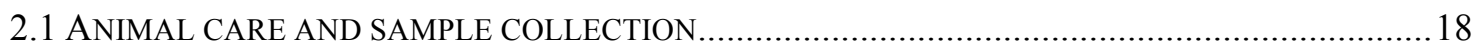

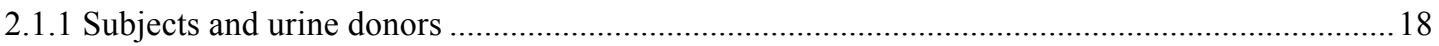

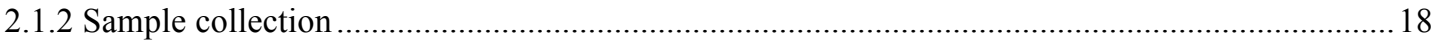

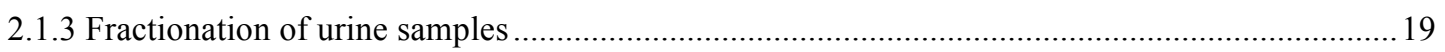

2.2 GAS CHROMATOGRAPHY/ MASS SPECTROMETRY (GC/MS) ............................................. 19

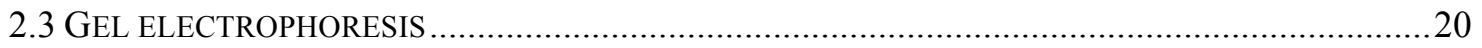

2.3.1 One-dimensional gel electrophoresis ................................................................................2

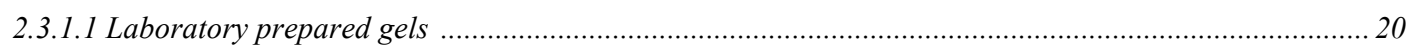

2.3.1.2 The Invitrogen NuPAGE gel system (pre-cast gels) ……………………………………….... 21

2.3.1.3 Protein identification ................................................................................................. 22

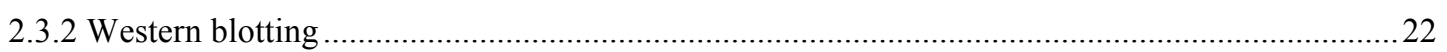

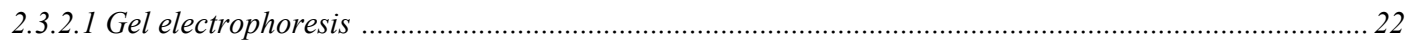

2.3.2.2 Western blot protein transfer ..................................................................................................... 22

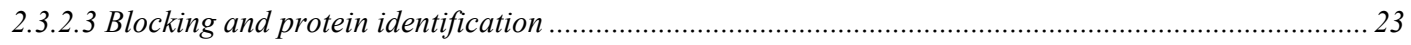

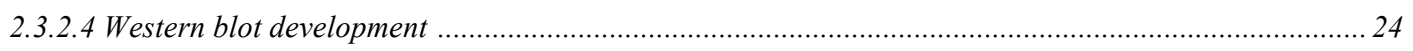

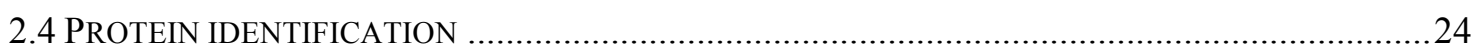

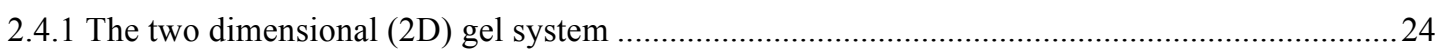

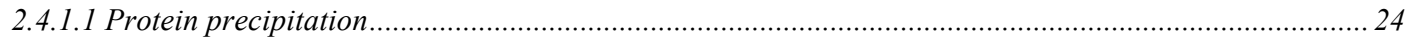

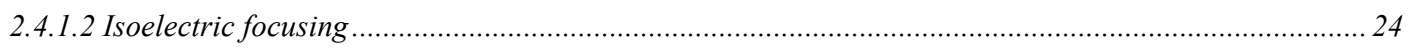

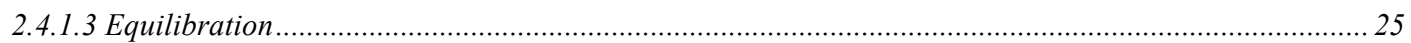

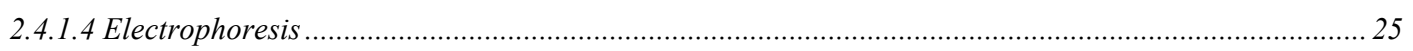

2.4.2 Preparation of protein spots for MALDI analysis...................................................................25

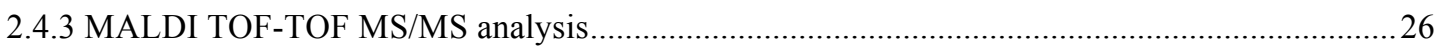

2.4.3.1 Calibration and acquisition of spectra for $M S$................................................................................ 26 


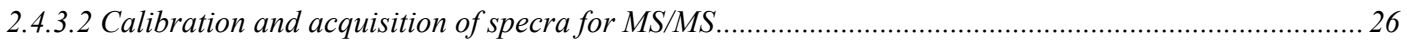

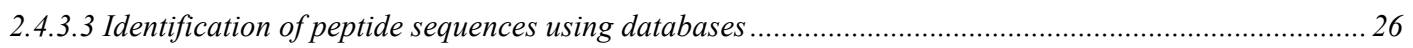

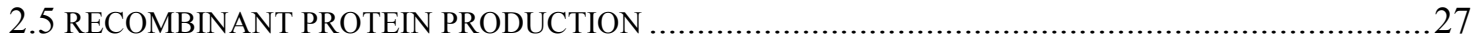

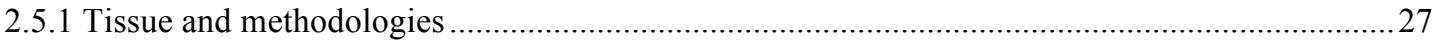

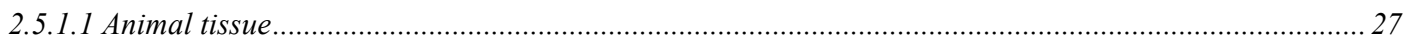

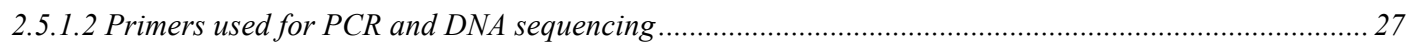

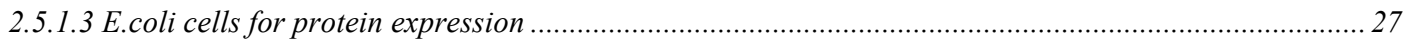

2.5.2 Identifying target MUPs using the BLAST database..............................................................28

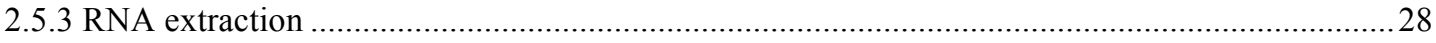

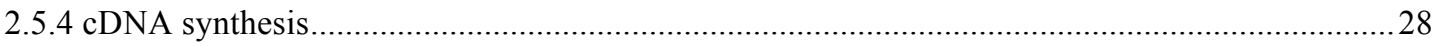

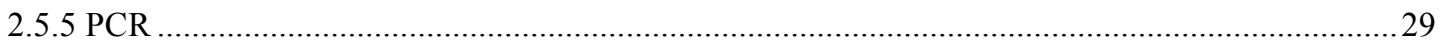

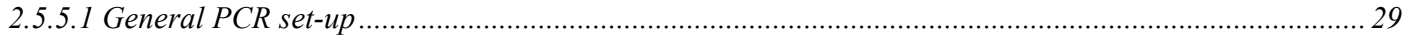

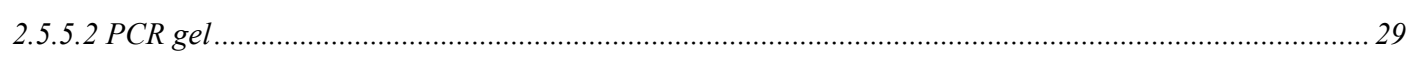

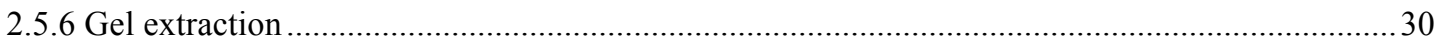

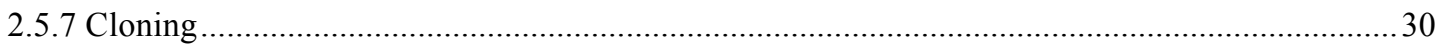

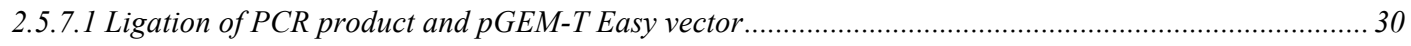

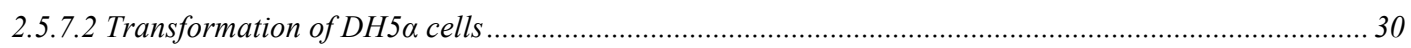

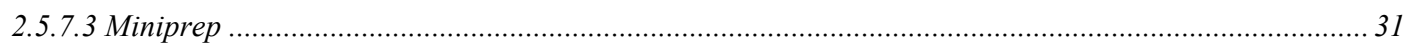

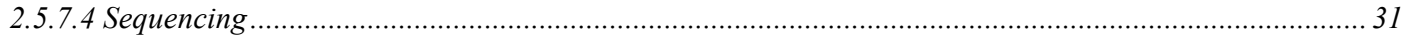

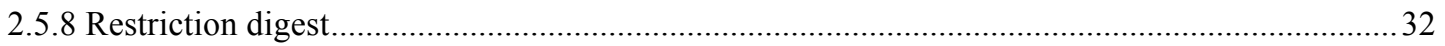

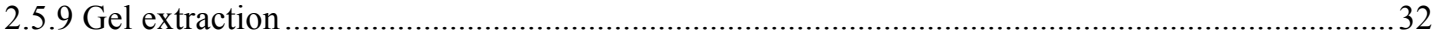

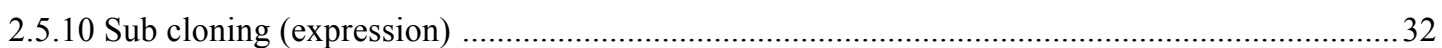

2.5.10.1 Ligation of gel extracted DNA and pET23b (+) or $p Q E-30$ vector ................................................... 32

2.5.10.2 Transformation of DH5 a cells, BL21(DE3)pLysS cells, and RosettaB(DE3)pLysS cells ................... 32

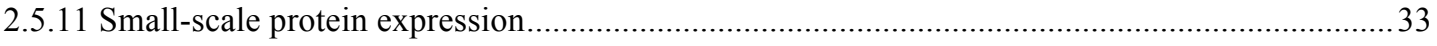

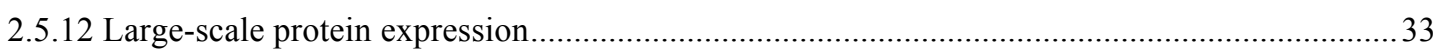

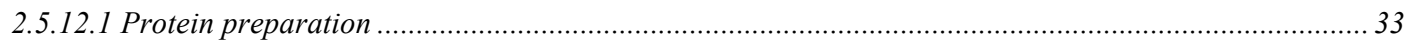

2.5.12.2 Solublisation of inclusion bodies ........................................................................................................ 33

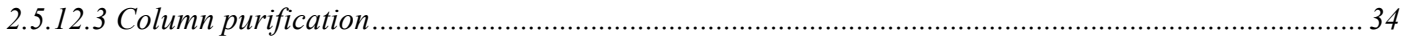

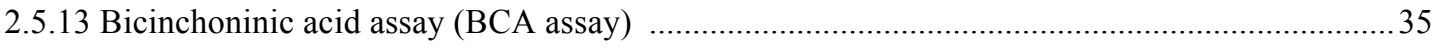

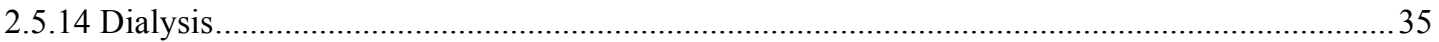

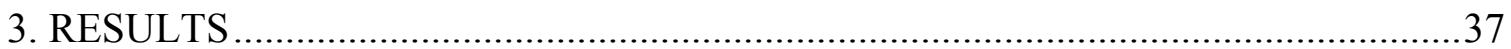

3.1 DETECTION OF PUTATIVE CHEMICAL ATTRACTANTS IN RAT URINE: VOLATILE ORGANICE

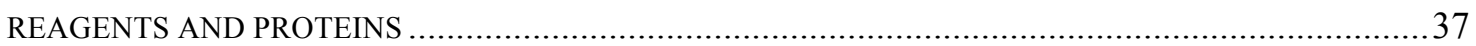

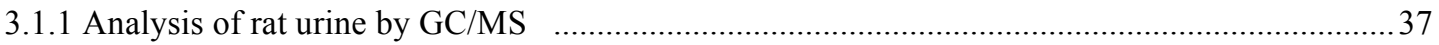

3.1.1.1 Identification of male specific compounds in urine from Norway and ship rats................................. 37

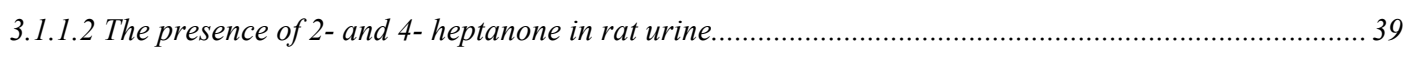

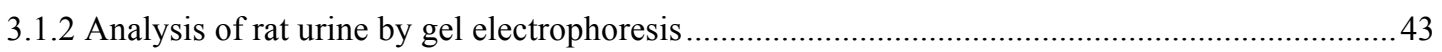

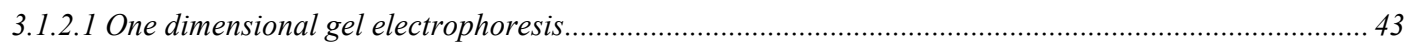

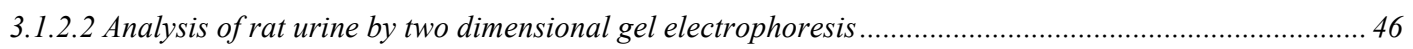

3.2 PRODUCTION OF RECOMBINANT PROTEIN .........................................................51 
3.2.1 Production of recombinant MUP in Norway rat.....

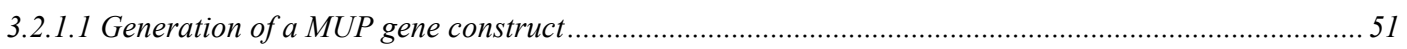

3.2.1.2 Expression and purification of MUP precursor in E. Coli........................................................... 57

3.2.2 Identification of MUP gene sequences in female Laboratory and wild ship rats .....................62

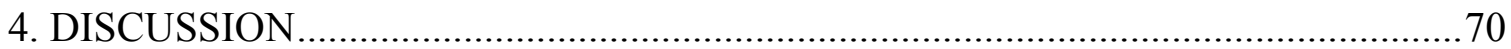

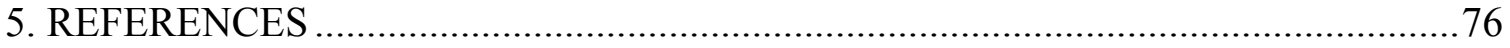

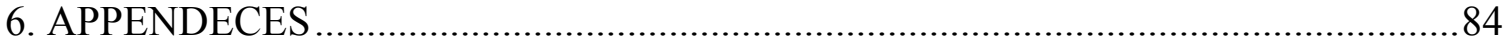




\section{General introduction}

Introduced mammals are responsible for the decline, and often the extinction, of much of New Zealand's native flora and fauna (Atkinson, 2006a). Rats are especially harmful due to their diverse range of diets and high reproductive rates (Clapperton, 2006). The latest developments in pest management now provide long-lasting, self-resetting traps that dispatch rats humanely (Jansen, 2011), but the potential of these traps is limited by the lack of effectiveness of lures. Because current lures are primarily foodstuffs and degrade quickly, the objective of this thesis is to identify new chemical lures to thereby enhance New Zealand's conservation efforts.

\subsection{Impact of pests in the New Zealand landscape}

Invading pests pose a serious threat to conservation efforts throughout the world. New Zealand's flora and fauna evolved in the almost complete absence of mammals. As a result, many display traits, such as naivety, or the inability to fly, make them especially susceptible to mammalian predators (Atkinson, 2006b). Of our native bird species, $42 \%$ have become extinct following the introduction of mammalian pests (Sax, Gaines, \& Brown, 2002). Furthermore, one species of bat, numerous insects, three frog species as well as several lizard and plant species have also been driven to extinction (Sax, Gaines, \& Brown, 2002). Exotic mammals were first introduced to NZ by Polynesian settlers in the 12-13 ${ }^{\text {th }}$ century, AD (Atkinson, 1973; Atkinson, 2006b). The first of these invasive pests to arrive was the Kiore (Rattus exulans), followed by a further 28 mammalian species that were brought over with the European settlement, which began in the 1870s. During the period of 1831-1860, feral sheep (Ovis aries), goats (Capra hircus), cats (Felis catus), ship rats (Rattus rattus), and possums (Trichosurus vulpecula) were all introduced. This was followed in 1861-1900 by the introduction of fallow (Dama dama), red (Cervus elaphus scoticus) and sambar deer (C. unicolor), rabbits (Oryctolagus cuniculus), two wallaby species, horses (Equus ferus caballus), feral pig (Sus scrofa), further possum introductions, stoats (Mustela erminea), ferrets, weasels (3 species), and hedgehogs (Erinaceus europaeus occidentalis) (Atkinson, 2006b).

Along with the ecological impacts that invasive species have on NZ's native species 
there are significant economical impacts. NZ has a \$20 billion dollar tourism industry, which is partly based upon our forests and our wildlife. One third of NZ is comprised of national parks and conservation areas, which make for appealing tourist destinations. Unfortunately, the conservation efforts needed to maintain these areas are costly. For example, in the 2006/7 financial year, the Department of Conservation (DOC) budget was $\$ 277.2$ million, with $23 \%$ being used to manage mammals (Carter, 2006).

Invasive species in $\mathrm{NZ}$ also contribute negatively to the economy because of the need to control mammals that act as vectors for Bovine tuberculosis (TB), which is caused by Mycobacterium bovis. The dairy, beef and venison trade in NZ contribute massively to the NZ economy by way of foreign earnings, and bovine TB threatens this trade. It is estimated that bovine TB alone causes a 5\% production loss of milk and meat products (Rosevear \& Urlich, 2010). The main mechanism for eliminating the disease is the "test and slaughter" approach, which can be a devastating economic cost to a farmer's income. This procedure while partially effective in minimising the spread of TB from high risk areas does not in itself control infection due to the main transmission vectors being possums and secondly, stoats. Close living conditions of these pests and their ease of infection cause major problems in transmitting the disease. Pigs, cats, hedgehogs, goats and sheep are also considered to be amplifier hosts, spreading TB when their carcasses are scavenged (Coleman \& Cooke, 2001). Therefore, vector control is used, aiming to decrease the populations of these pests to levels that decrease the chances of disease transmission. The annual cost to attempt to eliminate bovine TB in NZ is in excess of $\$ 80$ million. The potential of discovering more cost effective ways of eradicating pests would lessen the financial burden they cause (Parkes \& Murphy, 2003).

\subsection{Rat species in New Zealand}

The invasive pest shown to be the greatest threat to native species is the rat. There are three species of rat in New Zealand, the Norway rat (Rattus norvegicus), ship rat (Rattus rattus), and Pacific rat/ Kiore (Rattus exulans). The Pacific rat is currently thought to be restricted to parts of Southland and Fiordland and some offshore islands (Atkinson \& Towns, 2001). It has been suggested that competition with the two other species of rat 
caused this reduction in distribution (Watson 1956, Williams 1973). Watson (1956) also suggested that it might not only have been due to competition with other rats but with cats, mustelids, and also habitat destruction. An alternative observation was made that it may have been the presence of mice that caused the reduction in the kiore as all three species of rat were present where no mice were found (Taylor et al, 1975). Nevertheless unlike Kiore, both Norway and ship rats are distributed widely throughout NZ, and are known to be present on at least 42 offshore islands (Dowding \& Murphy, 1994; Innes, 1990).

Rat species have invaded NZ via human-assistance (e.g. boats) and self-dispersal, with invasion of new areas being capable of being completed within 2 years (Cowan, David, \& Roger, 2003). Both ship and Norway rats are equally able to invade both mainland areas as well as offshore islands. The swimming distances of rats vary but estimations indicate they are capable of traversing up to $3 \mathrm{~km}$ (Russell, Towns, \& Clout, 2008). One specific feature of the ship rats, which allows them to cause the most damage to NZ wildlife, is their excellent climbing ability. This allows them to gain access to most bird nests in trees. These animals also prey on large animals (e.g. Kiwi), as well as smaller animals such as weta. They are capable of eating the adults, eggs and chicks of many native birds, preying both day and night (Innes, 2001; Atkinson, 2006b).

\subsection{Efforts for pest eradication}

From baits to traps to culling, there are many forms of pest control currently used in NZ. DOC uses three main strategies for pest control, firstly the toolkit concept where they consider all the equipment available and apply what they deem suitable to a specific site. There are also ground control methods in which they use baits, traps and culling. These strategies are precise, but are also very labour-intensive and expensive. In addition aerial control is used when predator control is needed in areas too remote or too difficult to reach by foot. This strategy of aerial drops is also used when the population of predators is too high to manage with just bait and trap stations. Traps that are in current use are designed to avoid harming native birds. The most common poison being used is sodium monofluoroacetate, also known as 1080. This chemical is a synthetic form of a naturally-occurring, biodegradable toxin that in plants functions to deter browsing 
animals. In addition to these strategies for pest eradication current research is focusing on biological control aimed at reducing fertility is some species, particularly for possums (Cowan, David, \& Roger, 2003).

\subsection{Problems with current strategies}

On $29^{\text {th }}$ March 2000, the New Zealand Biodiversity Strategy was launched to take steps towards reversing the decline in New Zealand's indigenous biodiversity. To achieve this it was concluded that new tools and technologies are needed (Green \& Clarkson, 2006). As of now, only reductions in rat populations on the mainland have been evident and these remain temporary measures unless sustained control is applied to maintain numbers at low levels or unless specialised pest control fences are constructed (e.g. Karori Wildlife Sancuary-Zealandia). Conservation efforts using pest control have however resulted in rodents and other predators being eradicated entirely from several offshore islands in NZ There are three steps involved in planning for island biosecurity namely prevention, detection, and response to incursions (Russell et al., 2008). Incursions are defined as the arrival on an island of an animal but when no population has been established. Invasion comes after an incursion when an entire island is colonised. An 'incident' is an incursion where evidence for an animals presence is not definitive. It is deemed critical to stop pest presence at the incursion stage as the cost of attempting whole island eradication is expensive, time consuming and generally fruitless. In addition, due to the difficulty in detecting rodents when they exist in small populations, larger populations can form rapidly before conservationists become aware of the invasion (Dilks \& Towns, 2002; Clapperton, 2006). This poses a significant threat to the currently rodent-free islands in NZ as mice and rats exist in high concentrations around wharves and foreshore areas and easily stow away on ships or swim to islands. Upon reaching rodent-free islands, incoming rodents are often provided with a wide range of foods and little competition, making the establishment of a new population easy to achieve. It has been noted that $\sim 85 \%$ of rat incursions in NZ have been interrupted successfully by using traps and/or poisons. However, much more effective pest control strategies are needed to combat the high population of rats on the mainland and to enable $100 \%$ of incursions to be detected (Russell et al., 2008). A critical part of this strategy is an acknowledged need for an improved form of baiting to enhance the 
effectiveness of traps in capturing predators (Spurr et al., 2006; Spurr et al., 2007). A potential solution could come in the use of a chemical lure, to aid in attraction of animals to traps.

\subsection{Scent communication}

Scent communication plays a significant role in the behavior and reproductive processes in many animals. Two classes of stimuli are used to describe the components of animal scent. The first of these are the general odorants, which are low molecular weight compounds in the environment or food that convey information such as the presence of food, fire, and/or predators. The second, and most important for this study, are the pheromones, also referred to semio-chemicals in the literature. Pheromones are defined as single compounds that are released via a gland to the outside of the body and then received by another animal of the same species. The consequence of this signaling event is an alteration in a specific behavior or psychological process of the receptive animal (Karlson \& Luscher, 1959; Rekwot et al., 2001). Much is known about invertebrate pheromones and the behaviors they induce. Compared to mammals a plethora have been identified and these are widely used to examine the presence and abundance of insects, in addition to being used to protect animals and plants (Goodwin et al., 2006; Leal, 2013; Witzgall, Kirsch, \& Cork, 2010). Chemical signals in mammals are generally more complex than invertebrates, however they can be single compounds or mixtures of compounds, and their effect(s) can be dependent on either the presence or absence of a particular chemical or the relative quantities of individual chemicals in a mixture. They originate from a variety of different bodily fluids including, urine, breath, saliva, feces, anal gland and preputial gland secretions (Apps, 2013). The way, in which many mammals interpret them, including rodents is by a dual olfactory system. This includes the main olfactory system (MOE) which is found in the nasal cavity and the vomeronasal system (VNO) which is found between the nasal cavity and the mouth (Figure 1). The MOE is used to detect a range of different odorants, predominantly airborne volatiles, via mostly G-coupled receptors and the VNO has been shown to detect water-born pheromones and proteinaceous chemicals, though direct contact, via V1R and V2R receptors. Signals received by the VNO are projected to the accessory 
olfactory bulb (OBE), this transmits the signal to the basal forebrain, an area shown to be involved in mating and reproductive behavior (Leal, 2013).

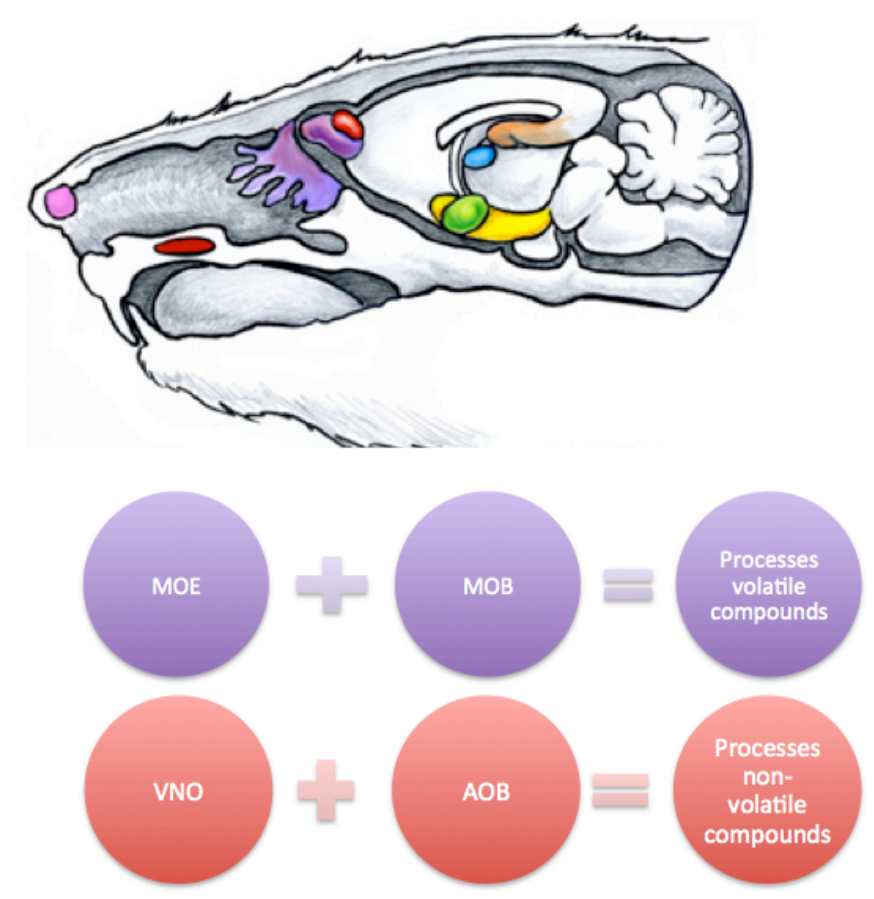

Figure1 The rodent olfactory system. The main olfactory epithelium (MOE) and main olfactory bulb (MOB) are shown in purple, which process volatile compounds. The vomeronasal organ (VNO) and accessory olfactory bulb (AOB) are shown in red, this processes non-volatile compounds upon direct contact. The signal is processed via other structures of the limbic system; these include the amygdala (green), bed nucleus of stria terminalis (blue), and hypothalamus (yellow). Image adapted from Wired for behavior: from development to function of innate limbic system circuitry (Sokolowski \& Corbin, 2012).

Certain behaviors in rodents have been shown to be regulated by these chemical signals: these include aggression, mating, acceleration or delay of puberty, territory establishment, and dominance (Novotny et al., 1985; Novotny et al., 1986; Harvey, \& Jemiolo, 1990; Jemiolo et al., 1991; Novotny et al., 1999). For example, male mice advertise their location and territorial dominance with their urine scent and when another male mouse is exposed to this scent it counter marks with its own urine in a dominant manner. In addition to these behavioral responses, pheromones are thought to indicate specific features about the animal it came from, including age, sex, and species (Beynon \& Hurst, 2004). These features can provide females of the same species, information about the male that will affect mate selection. Laboratory rodents have also 
been shown to be capable of identifying the body odor of high or low ranking males, with females generally having a preference for dominant males (Drickamer, 1997). The identity of many of these communication signals in mammals remains largely unknown,

especially when compared to the knowledge of insect pheromones. However, some volatile compounds and proteins have been identified in rodents as playing the role of pheromones in communication (discussed below).

\subsection{Volatiles}

Chemicals with a high evaporation rate (e.g. volatiles) are an important component of rodent scent and are detected via the olfactory system. The role they play in mice communication and behavior is relatively understood, and specific signaling volatiles have been identified. For example $(E, E)$ alpha-farnesene and $(E)$ beta-farnesne have been identified in the pre-putial gland of male mice, in addition to 2-sec-butyl-4,5dihydrothiazole and 2,3-dehydro-exo-brevicomin which have been found in male mouse urine. These volatiles have been shown to cause puberty acceleration in female mice, and aggression in males (Novotny et al., 1985; Novotny et al, 1999). Very few volatiles in rat urine have been identified, and generally studies have produced conflicting results (Osada, Kashiwayanagi, \& Izumi, 2009; Selvaraj \& Archunan, 2002; Zhang et al., 2007). Nevertheless, it has been suggested that 2- heptanone, 4- heptanone, 4methylphenol, and 4-ethylphenol play a role in female attraction (Osada, Kashiwayanagi, \& Izumi, 2009). To persist in the environment, these volatiles need to associate with proteins, which allow for their slow release. 


\subsection{Major urinary proteins}

Lipocalins are family of extracellular proteins that share several common characteristics. An important characteristic of these proteins is the hydrophobic residues that line their central cavity. These residues are responsible for the forces that bind the apolar ligands that fit into these cavities. Additionally all lipocalins are made up of an eight-stranded beta-barrel fold (Figure 2) (Flower, 1996). Of importance to this study is a member of this family, the major urinary proteins (MUPs). These are present in both mice and rats, with many similarities between the species. The literature uses two terms to describe these proteins in rats; MUPs or $\alpha_{2 u-}$ globulins (A2U): in this thesis they will be referred to as MUPs.

a.

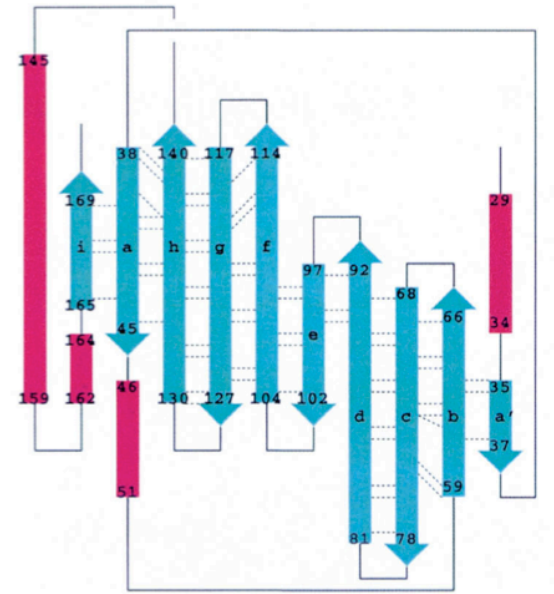

b.

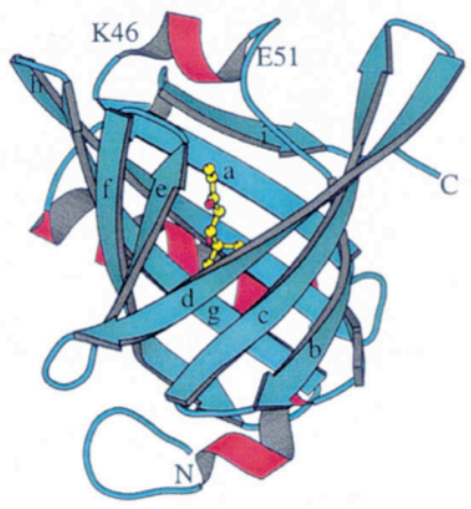

Figure 2 The structure of a mouse MUP (MUP-1). a. This topology diagram highlights the main chain hydrogen bond pattern (broken lines) between $\beta$-strands in a mouse MUP $\beta$-barrel. b. A ribbon diagram binding to a mouse volatile (6-hydroxy-6-methyl-3-heptanone), as seen from the entrance to the $\beta$-barrel. Used with permission from Pheromones, binding proteins and receptor responses in rodents (M. V. Novotny, 2003)

MUPs are polymorphic proteins that are synthesized in the liver, with 3.5-4 \% in mice and $\sim 1 \%$ in rat protein production being MUPs (Sippel et al., 1976; Cavaggioni \& Mucignat-Caretta, 2000). These proteins then travel via the blood stream to the kidneys; where they are excreted in the urine. There is compelling evidence to suggest that MUP production is under hormonal control in rats (Roy \& Otto, 1967), as the administration of testosterone to castrated males and intact female rats increased its presence in urine. 
In contrast, estrogen given to males decreased MUP production. Furthermore the removal of both the testes and pituitary gland prevented MUP synthesis in rats, however testes removal alone did not have this effect (Kumar, Roy, \& Axelrod, 1969). Adult male mice have been shown to excrete approximately 5-10 $\mathrm{mg}$ of protein in their urine per day (Cavaggioni \& Mucignat-Caretta, 2000), 1-5 mg/ mL of which contains MUPs (Sharrow et al., 2002). Male rats excrete urine at a volume of 5.5-6.2 mL/24 h/100 g body weight and excrete $30-100 \mathrm{mg} / 100 \mathrm{~mL}$ of protein daily (Suckow, Weisbroth, \& Franklin, 2006), with $30-50 \%$ of this total protein output containing MUPs (Roy, Neuhaus, \& Harmison, 1966). It has been reported that females have less MUPs than males, and that sex specific MUPs have been noted (Held \& Gallagher, 1985). MUPs range in size from $17-23 \mathrm{kDa}$, in addition to being acidic with an isoelectric point ranging from 4.2- 6.7 (Duncan et al., 1988; Flower, 1996).

It has been shown that the MUP gene cluster is composed of two subgroups, an older more divergent class of genes and psuedogenes, and a second class with high sequence identity formed by sequential duplications of a single gene/pseudogene pair. Analyses of complete genomes have shown that MUP genes have diverged independently through different lineages (e.g. rat, horse, grey mouse lemur) (Figure 3). This indicates that the increasing genomic complexity of the MUP gene family is not evolutionarily isolated (Logan, Marton, \& Stowers, 2008). In mice, approximately 15-25 MUP genes have been found to be clustered on chromosome 4, with approximately 18-20 rat MUP genes identified on chromosome 5 (Hastie, Held, \& Toole, 1979; Kurtz, 1981; Bishop, 1982; Krauter et al., 1982;). MUPs are polymorphic in both rats and mice (van Zutphen et al., 1981) and most of the sequence variations are in surface amino acids, although there are some in the binding cavity and these can affect their shape (Marie et al., 2001). 


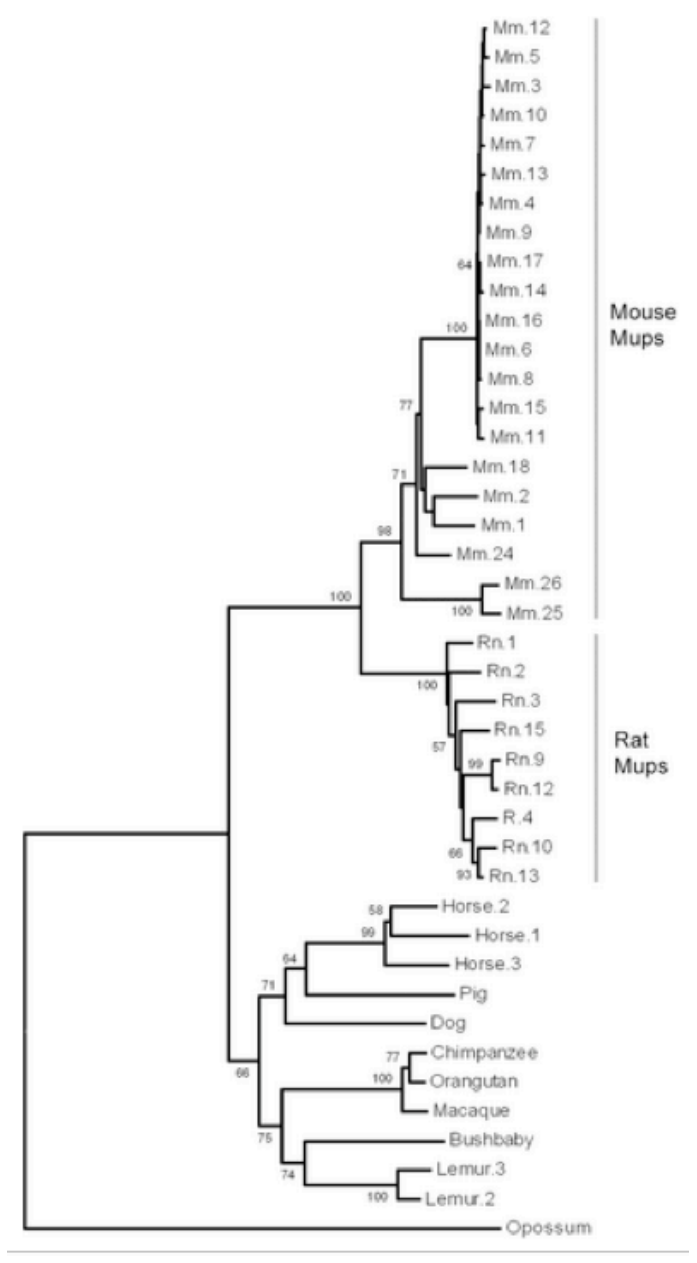

Figure 3 Phylogenetic tree of MUP coding sequences in mammals; indicating the mouse and rat MUP gene repertoires expanded independently, after the rodent species diverged. Used with permission from Species specificity in major urinary roteins by parallel evolution (Logan et al., 2008).

The main function of MUPs is to act as pheromone transporters and stabilisers. In this way they act to protect the volatile pheromone and allow their slow release into the environment (Beynon \& Hurst, 2004). The complex patterns of MUPs can potentially provide significant information about each animal such as gender, fertility, age, social dominance, kinship and genetic diversity. However, the proteins themselves, could potentially function as chemo-signalling molecules, contributing to interspecies communication and scent mark ownership (Beynon \& Hurst, 2004; Beynon et al., 2002). Evidence for this was that MUPs were found to emit a response in the absence of ligands (Humphries et al.,1999). Moreover, a recombinant male mouse MUP, Darcin, was found to be sexually attractive to female rats (Roberts et al., 2010). 


\subsection{Aims}

The focus of this thesis will be on developing a chemical lure specific to ship rats as they pose the greatest threat to New Zealand native species. The hypothesis being explored herein was that male ship rats express a protein in their urine that has the ability to attract female rats. If identified, this protein could be used as a lure to identify the presence of an existing cohort or that of an invading population of rats. It would also allow for improvements in trapping techniques by providing an attractant to localize the presence of an invasive rat species. In order to test this hypothesis two aims were established. The first was to examine the protein and volatile organic components of ship rat urine with a special emphasis on identifying differences between the sexes. Norway rats were also investigated for the purpose of method development. The second aim was to produce a synthetic rat major urinary protein (MUP). If a pheromone or chemical attractant can be developed that attracts rats for monitoring, trapping or poisoning, it is anticipated that this will make a significant contribution to the conservation efforts aimed at enhancing populations of NZ native species. 


\section{Material and methods}

\section{1 Animal care and sample collection}

The experimental procedures involving the use of rodents in these studies were approved by the Victoria University Animal Ethics Committee (approval number 2011R4).

\subsubsection{Subjects and urine donors}

B6 mice (Mus musculus), BALB/c mice (Mus musculus), and Norway rats (Rattus norvegicus) that were used for urine collection were gifted by the School of Psychology at Victoria University of Wellington. A colony of wild ship rats (Rattus rattus) and another of wild Norway rats (Rattus norvegicus) were also established by humane trapping at various locations in Wellington, New Zealand. One trapped ship rat and one Norway rat each gave birth in captivity. The rats were housed in $17 \mathrm{~cm} \mathrm{x} 40 \mathrm{~cm}$ x $17 \mathrm{~cm}$ cages in same-sex groups of two for laboratory Norway rats and singularly for the wild ship and Norway rats. The mice were housed in groups of 4-6 in cages that were $12 \mathrm{~cm}$ long, $30 \mathrm{~cm}$ wide, and $17 \mathrm{~cm}$ high. All animals were housed under the following environmental conditions: temp, $\sim 21^{\circ} \mathrm{C}$; humidity, $55 \%$; a 12/12 h light/dark cycle with lights on at 7 am and; laboratory chow and tap water ad libitum except during the periods of testing.

\subsubsection{Sample collection}

Urine from four male and four female laboratory Norway rats, one male and four female wild Norway rats, and four male and five female wild ship rats was collected by placing one rat at a time on a sterile aluminium tray inside a cage with only water available until it had urinated. Urine was also collected from six male and six female B6 mice, and six $\mathrm{Balb} / \mathrm{c}$ male and six female mice. These collections were performed by holding the mice by the neck over a clean $1.5 \mathrm{~mL}$ centrifuge tube. Subsequently the urine was pooled by sex and strain then collected by pipette and transferred into a $1.5 \mathrm{~mL}$ centrifuge tube, capped and stored at $-20^{\circ} \mathrm{C},-80^{\circ} \mathrm{C}$ or fractionated immediately. 


\subsubsection{Fractionation of urine samples}

Proteins were separated into high molecular weight (HMW) and low molecular weight (LMW) components using Vivaspin ${ }^{\mathrm{TM}} 2$ Centrifugal Concentrators (GE Healthcare). This process allowed for the separation of a liquid sample into two fractions. One fraction contained the proteins and all other urine components smaller than the size cutoff as they pass through the membrane filter. The other contained everything above the cutoff, which is trapped above the membrane and eluted separately. The Vivaspin concentrators were washed once using $\mathrm{dH}_{2} \mathrm{O}$ (4 min, $3220 \mathrm{xg}$ ). The $\mathrm{dH}_{2} \mathrm{O}$ was removed and then urine was added to a $30 \mathrm{kDa}$ cut-off Vivaspin concentrator at a volume dependent upon the amount collected $(\sim 200 \mu \mathrm{L})$. After addition, the urine was centrifuged twice at $3200 \mathrm{x}$ g for $4 \mathrm{~min}$. The filtrate was then removed and added to a 5 $\mathrm{kDa}$ cut off Vivaspin concentrator and centrifuged twice at $32000 \mathrm{xg}$ for $4 \mathrm{~min}$. The filtrate was removed by pipette and stored in a capped $1.5 \mathrm{~mL}$ centrifuge tube at $-80^{\circ} \mathrm{C}$. Initial attempts to obtain the retentate (anything between $5-30 \mathrm{kDa}$ ) containing the major urinary proteins (MUP) involved the addition of $\mathrm{dH}_{2} \mathrm{O}$ to the bottom section of the Vivaspin concentrator, which was then centrifuged twice upside down at $3200 \mathrm{x} g$ for $4 \mathrm{~min}$. This protocol was adapted to avoid diluting the urine samples. This involved turning the vivaspin upside down and centrifuging twice at $3200 \mathrm{xg}$ for $4 \mathrm{~min}$. The retentate was pipetted into a capped $1.5 \mathrm{~mL}$ centrifuge tube and stored at $-80^{\circ} \mathrm{C}$. To determine the protein concentration of these urine samples a 2-D Quant Kit (GE Healthcare Life Sciences) was used, however this proved to be unsuccessful in detecting any protein.

\subsection{Gas Chromatography/Mass Spectrometry}

Gas chromatography was performed with a Shimadzu GCMS-QP2010 Plus equipped with a Restek Rtk-5ms column (30 m x 0.25 mm ID x $0.25 \mu \mathrm{m}$ film thickness. The urine samples of all laboratory Norway, wild Norway and wild ship rats were pipetted into clear screw top $20 \mathrm{~mL}$ head space vials and pre-heated in a water bath at $64-65^{\circ} \mathrm{C}$ for $15 \mathrm{~min}$. The samples were extracted in the water bath with a DVB/Carboxen/PDMS SPME fibre (Phenomenex) ( $2 \mathrm{~cm} \times 50 \backslash 30 \mu \mathrm{M}$ coating) into the head space vials for $1 \mathrm{~h}$. The SPME fiber was inserted into the GCMS inlet in splitless mode and desorbed at 
$270^{\circ} \mathrm{C}$ for $1 \mathrm{~min}$, after which it was removed. Helium was used as the carrier gas with a column flow rate of $1.18 \mathrm{~mL} / \mathrm{min}$. The programmed temperature started at $50^{\circ} \mathrm{C}$ for 2 min, then increased to $300^{\circ} \mathrm{C}$ at a rate of $6^{\circ} \mathrm{C} / \mathrm{min}$, and held for $5 \mathrm{~min}$. GCMS data was acquired with Shimadzu's Real-Time Analysis and analysed using the Post-Run Analysis software used for data processing. Compound identification was performed by comparison of electron impact fragmentation patterns $(70 \mathrm{eV})$ with the NIST08 libraries of mass spectra and an in-house generated library. Tentative identifications based on mass spectral fragmentation patterns were included if the similarity score was $>85$. The urine sample concentrations were not determined.

\section{3 Gel electrophoresis}

\subsubsection{One-dimensional gel electrophoresis (1D)}

\subsubsection{Laboratory prepared gels}

This system was used for running samples from Section 2.6. Gels were prepared at $15 \%$ bis-acrylamide, using the following composition:

\begin{tabular}{ll}
\hline Solution & Volume \\
\hline $\mathrm{dH}_{2} \mathrm{O}$ & $2.35 \mathrm{~mL}$ \\
Tris-HCl $1.5 \mathrm{M}, \mathrm{pH} 8.8$ & $2.5 \mathrm{~mL}$ \\
$\mathrm{SDS} 10 \%(\mathrm{w} / \mathrm{v})$ & $0.1 \mathrm{~mL}$ \\
Bis-acrylamide $(30 \%)$ & $5.0 \mathrm{~mL}$ \\
Ammonium persulfate $10 \%(\mathrm{w} / \mathrm{v})$ & $50 \mu \mathrm{L}$ \\
TEMED & $5 \mu \mathrm{L}$ \\
\hline
\end{tabular}

Once the solution was made it was added to a glass plate set in casting frames. After the gel had polymerised, a stacking gel solution with the following composition was layered above the separating gel: 


\begin{tabular}{ll}
\hline Solution & Volume \\
\hline $\mathrm{dH}_{2} \mathrm{O}$ water & $3.05 \mathrm{~mL}$ \\
Tris- $\mathrm{HCl} 0.5 \mathrm{M}, \mathrm{pH} 6.8$ & $1.25 \mathrm{~mL}$ \\
$\mathrm{SDS} 10 \%(\mathrm{w} / \mathrm{v})$ & $50 \mu \mathrm{L}$ \\
Bis-acrylamide $(30 \%)$ & $0.65 \mathrm{~mL}$ \\
Ammonium persulfate $10 \%(\mathrm{w} / \mathrm{v})$ & $25 \mu \mathrm{L}$ \\
TEMED & $5 \mu \mathrm{L}$ \\
\hline
\end{tabular}

A 10 well or 15 well comb was added to the stacking gel.

Samples were combined with either a $2 \mathrm{x}$ or $5 \mathrm{x}$ loading buffer $[0.5 \mathrm{M}$ tris- $\mathrm{HCl} \mathrm{pH} 6.8$, glycerol, 10\% (w/v) SDS, DTT, 1.0\% (w/v) bromophenol blue, $\mathrm{dH}_{2} \mathrm{O}$ ] and heated at $95^{\circ} \mathrm{C}$ for $5 \mathrm{~min}$. Pre-stained SDS-PAGE Standards (Bio-Rad, Cat \# 161-0318), Precision Plus Protein ${ }^{\mathrm{TM}}$ Dual Color Standards (Bio-rad, Cat \# 161-0374), and a BenchMark pre-stained protein ladder (Invitrogen, Cat \# = 10748-010) were all used as protein standards at different times, depending on availability. Samples were loaded, and the gels run in a 4-gel vertical electrophoresis cell (Mini-PROTEAN Tetra Cell, Bio-Rad, NZ) with 1x running buffer (glycine, tris, SDS) for approximately 1 h $40 \mathrm{~min}$ at $150 \mathrm{~V}$.

\subsubsection{The Invitrogen NuPAGE gel system (pre-cast gels)}

The urine samples were subjected to SDS-PAGE (Section 2.2.3) using either NuPAGE 4-12\% Bis-Tris 1.0mm, 12 well gels (Cat \# = NP0322BOX) or NuPAGE® Novex 12\% Bis-Tris1.0 mm, 12 well gels (Cat \# = NP0342BOX). The protocol followed was that supplied by the manufacturer (Invitrogen). Samples mixed with NuPAGE® LDS Sample Buffer (4X) (Invitrogen) were placed in a heating block at $70^{\circ} \mathrm{C}$ for $10 \mathrm{~min}$. The precast gel was unpacked and rinsed with $\mathrm{dH}_{2} \mathrm{O}$ water and the attached comb was removed carefully. Thereafter, the gel was inserted into a gel chamber and the chamber filled with either 1 x MOPS buffer (Invitrogen) or 1 x MES buffer (Invitrogen). NuPAGE® Antioxidant (Invitrogen) was added to the center chamber and then the gel was run at $200 \mathrm{~V}$ for $1 \mathrm{~h}$. 


\subsubsection{Protein identification}

Protein bands on laboratory-prepared gels were visualised using Coomassie blue stain (Coomassie Brilliant Blue R-250 (Bio-Rad) 0.1\% (w/v), methanol 40\% (v/v), acetic acid $\left.10 \%(\mathrm{v} / \mathrm{v}), \mathrm{dH}_{2} \mathrm{O} 50 \%(\mathrm{v} / \mathrm{v})\right)$. The protocol used for the laboratory-made gels involved the gels being immersed for $1 \mathrm{~h}$ at room temperature in Coomassie blue stain on a shaking table. Thereafter, the staining solution was removed and the gel was placed in a destain solution [methanol 40\% (v/v), acetic acid 10\% (v/v), $\mathrm{dH}_{2} \mathrm{O} 50 \%(\mathrm{v} / \mathrm{v})$ ] overnight at room temperature. The gel was then left in the destain solution or $\mathrm{dH}_{2} \mathrm{O}$ water until scanned using a GE Healthcare Image Scanner III (GE Healthcare, Uppsala, Sweden). The staining protocol used for precast gels involved the SDS-PAGE gel being put in a fixing solution (50\% ethanol, $3 \%$ phosphate acid) for $30 \mathrm{~min}$ or overnight. The gel was rehydrated by washing with $\mathrm{dH}_{2} \mathrm{O} 3 \mathrm{x}$, for $30 \mathrm{~min}$ each. Subsequently, the gel was put in a staining solution consisting of $17 \%$ ammonium sulfate, $34 \%$ methanol, and $3 \%$ phosphoric acid for approximately $10 \mathrm{~min}$, after which Coomassie Brilliant Blue G250 powder (Bio-Rad) was added and the gel was then left either overnight or for up to two days, depending on how intensely the protein bands were stained. The gel was then washed $3 \mathrm{x}$ for 30 min each with $\mathrm{dH}_{2} \mathrm{O}$ or until background staining was minimal, then scanned using ImageScanner III (GE Healthcare Life Sciences).

\subsubsection{Western blotting}

\subsubsection{Gel electrophoresis}

The gels for western blotting were prepared and run using the same protocols as described for the 1D gels using laboratory made gels and the precast gel system.

\subsubsection{Western blot protein transfer}

The proteins on the electrophoresed gels were transferred onto a Hybond $\mathrm{C}+$ membrane (GE Healthcare Life Sciences). Transfer blotting paper was pre-soaked in western transfer buffer (259 $\mathrm{mM}$ tris, $2 \mathrm{M}$ glycine, 20\% methanol), and the transfer sandwich was assembled in a western blot cassette (BioRad, NZ) in the following order:

1. Red side of cassette

2. Fibre pad

3. Blotting paper 
4. GE Hybond $\mathrm{C}+$ membrane

5. Gel

6. Blotting paper

7. Fibre pad

8. Black side of cassette

The cassette was then inserted into a Mini Trans-Blot ${ }^{\circledR}$ Cell (Bio-rad, NZ) as per manufacturer's instructions and the cell was connected to a power pack and run for $1 \mathrm{~h}$ at $100 \mathrm{~V}$, at $4^{\circ} \mathrm{C}$.

\subsubsection{Blocking and protein detection}

At the end of the western blot transfer, the membrane was washed $2 \mathrm{x}$ each for $10 \mathrm{~min}$ in TBS (20 mM Tris HCl, pH 7.5, $150 \mathrm{mM} \mathrm{NaCl,} \mathrm{0.1 \%} \mathrm{Tween20).} \mathrm{This} \mathrm{was} \mathrm{followed} \mathrm{by}$ $1 \mathrm{~h}$ incubation of the membrane in 5\% blocking buffer $(5 \mathrm{~g}$ low fat milk powder in 50 $\mathrm{mL}$ TBS). Thereafter, the membrane was then incubated with the detecting (i.e. primary) antibody, monoclonal mouse Anti-His Antibody (GE Healthcare) or rabbit polyclonal MUP Antibody FL-180 (Santa Cruz Biotechnology), in 5\% (w/v) blocking buffer (milk powder in TBS) for a minimum of $2 \mathrm{~h}$, then washed $3 \mathrm{x}$ each for $10 \mathrm{~min}$ in wash buffer. A secondary antibody, peroxidase-conjugated affinity pure rabbit antimouse IgG (Jackson ImmunoResearch) or Anti-rabbit IgG (Jackson ImmunoResearch) was then added in 5\% blocking buffer for a minimum of $2 \mathrm{~h}$, followed by three successive washes for $10 \mathrm{~min}$ in wash buffer. All the blocking and protein detection steps were carried out at room temperature. Following this was Western blot development.

\subsubsection{Western blot development}

The membrane was covered in a freshly mixed detection solution $(250 \mathrm{mM}$ luminol, 90 $\mathrm{mM}$ p-coumaric acid, $1 \mathrm{M}$ tris $\mathrm{pH} 8.5$, hydrogen peroxide $30 \%$ ) and incubated for 30 sec to $1 \mathrm{~min}$. The membrane was then covered in cling film and placed in an X-ray cassette. In the dark, X-ray (Fujifilm) film was exposed to the membrane for various time points ranging from $1 \mathrm{sec}$ to $7 \mathrm{~min}$, depending on the intensity of the signal. The film was then placed in developer solution (GBX developer solution, Kodak international) for $3 \mathrm{~min}$, water for $1 \mathrm{~min}$, fixer (GBX fixer solution, Kodak international 
for $3 \mathrm{~min}$ and then a final wash in water for $1 \mathrm{~min}$. The film was left to dry then scanned with a photocopier.

\subsection{Protein identification}

\subsubsection{The two dimensional (2D) gel system}

To further investigate the protein composition of rat urine, samples were analysed by 2D gel electrophoresis. The samples used were urine fractions containing proteins in the size range 5-30 kDa, from four individual male laboratory Norway rats, four female laboratory Norway rats, four male wild ship rats and four female wild ship rats.

\subsubsection{Protein precipitation}

Proteins were precipitated using the Calbiochem Protein Extract Protein Precipitation Kit (Merck, Darmstadt, Germany). Precipitant was added to protein extracts from urine samples and the samples were then incubated at $-20^{\circ} \mathrm{C}$ for at least $1 \mathrm{~h}$. They were then centrifuged at $13,000 \mathrm{x} \mathrm{g}$ for $10 \mathrm{~min}$. The supernatant was discarded and wash buffer was added to each pellet. The samples were vortexed briefly and again centrifuged at $13,000 \mathrm{x} g$ for $5 \mathrm{~min}$. The wash step was repeated and the pellets were allowed to dry at room temperature for $30 \mathrm{~min}$, after which they were re-suspended in rehydration buffer.

\subsubsection{Isoelectric focusing}

Protein samples were separated by IEF on $7 \mathrm{~cm}$ Immobiline DryStrips (GE Healthcare Bio-Sciences A.B, Uppsala, Sweden). The previously precipitated protein pellets were re-suspended in rehydration buffer (2 M thiourea, $7 \mathrm{M}$ urea, 2\% DTT, 4\% CHAPS, trace bromophenol blue, 2\% IPG buffer (GE Healthcare). Samples were loaded onto $\mathrm{pH}$ 4-7 Drystrips by passive loading. Rehydration was then undertaken in an Immobiline DryStrip Re-swelling tray (GE Healthcare) and mineral oil (PlusOne DryStrip cover fluid, GE Healthcare) was used to cover each strip.

\subsubsection{Equilibration}

Equilibration of the Immobiline DryStrips was done with $2 \times 10$ min incubations with equilibration buffer [50 mM tris- $\mathrm{HCl}(\mathrm{pH} 8.8), 6 \mathrm{M}$ urea, 30\% v/v glycerol, $2 \% \mathrm{w} / \mathrm{v}$ 
SDS]. The first 10 min incubation was in 1\% DTT equilibration buffer and the second in $2.5 \%$ IAA equilibration buffer.

\subsubsection{Electrophoresis}

The second dimension SDS-PAGE was carried out under the same conditions as for 1DE gels on $4-12 \%$ Bis-Tris ZOOM ${ }^{\mathrm{TM}}$ gels (NuPAGE®, Invitrogen).

\subsubsection{Preparation of protein spots for MALDI analysis}

Protein spots were recovered using a spot picker (OneTouch Plus Spot/Band picker PDM1.5, The Gel Company, San Francisco, California) or a clean razor blade. These selected gel pieces were washed using a de-staining solution at room temperature (50 $\mathrm{mM}$ ammonium bicarbonate, 50\% methanol) until the gel pieces were clear: this was achieved by changing the solution every 1-3 $\mathrm{h}$. When fully de-stained, the samples were placed in fresh de-stain solution overnight. The next day, approximately $100 \mu \mathrm{L}$ acetonitrile $(\mathrm{ACN})$ was added to each gel sample for 3-5 min, before being removed and discarded. The gel samples needed to be fully dehydrated and restored to a bright white appearance. Thereafter, these gel samples were left to dry by allowing the ACN to evaporate and then the samples were stored at $4{ }^{\circ} \mathrm{C}$ until needed. Sequencing grade trypsin (modified sequencing grade. Roche Cat \# 1418025001), was resuspended in 50 $\mathrm{mM}$ ammonium bicarbonate to achieve a concentration of $25 \mathrm{ng} / \mu \mathrm{L}$. This solution was then added to each dried gel sample and left for $30 \mathrm{~min}$ at room temperature, followed by an addition of $50 \mathrm{mM}$ ammonium bicarbonate and incubated overnight at room temperature. The digest solution was then transferred to a new well. An extraction solution, $30 \mu \mathrm{L},(50 \% \mathrm{ACN}, 0.1 \%$ trifluoroacetic acid (TFA) was then added to each gel sample and incubated for $60 \mathrm{~min}$ at room temperature. The solution was then removed, added to the previous digest solution, and this was repeated for a total of three extractions. The resulting peptides were then dried overnight in a laminar flow hood, and stored at $-20{ }^{\circ} \mathrm{C}$ for mass spectrometric analyses. For analyses, proteins were

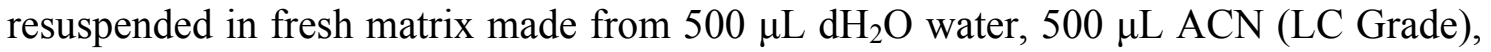
$1 \mu \mathrm{L}$ TFA, and 7-8 mg $\alpha$-cyano-4-hydroxycinniamic acid (CHCA). The matrix was vortexed for 1-2 min and then centrifuged for $2 \mathrm{~min}$ at $1400 \mathrm{x} \mathrm{g}$. The resuspended peptide extracts were spotted onto a 384 Opti-TOF 123x81 plate. 


\subsubsection{MALDI TOF-TOF MS/MS Analysis}

The MALDI TOF-TOF MS/MS sample analysis was undertaken using an AB Sciex TOF/TOF 5800 mass spectrometer (Applied Biosystems, Foster City, CA) equipped with a diode pulse laser $(355 \mathrm{~nm}, 1 \mathrm{kHz})$. The spectrometer was controlled by TOF/TOF ${ }^{\mathrm{TM}}$ Series Explorer ${ }^{\mathrm{TM}}$ software.

\subsubsection{Calibration and acquisition of spectra for MS}

Calibration of the MS was established using the CalMix2 (Applied Biosystems) monoisotopic peaks for angiotensin I (m/z 1296.6853), adrenocorticotropic hormone (ACTH) clip 1-17 (m/z 2093.0867), ACTH clip 18-39 (m/z 2465.1989) and ACTH clip $7-38(\mathrm{~m} / \mathrm{z}$ 3657.9294). The mass tolerance for the calibration was 0.1-0.3 Da and at least 4-5 peaks were matched. The laser intensity was fixed at $4500-4900$ with a pulse rate of $400 \mathrm{~Hz}$. Spectra for MS analyses were acquired in positive reflector mode with CID off. The laser was fired in a uniform random pattern.

\subsubsection{Calibration and acquisition of spectra for MS/MS}

The calibration involved the use of the monoisotopic angiotensin one peak (1296.800 $\mathrm{Da}$ ) for the selected precursor ion. The mass tolerance was $0.08-0.3 \mathrm{Da}$ and a minimum of 4 peaks had to be matched. The laser intensity was fixed at 4500-4900 with a pulse rate of $400 \mathrm{~Hz}$. Spectra for MS/MS analyses were acquired in $1 \mathrm{kV}$ positive reflector mode, with CID and metastable ion suppressor on. The laser was fired in a uniform random pattern.

\subsubsection{Identification of peptide sequences using databases}

Peptide fingerprints and MS/MS sequences were imported into the Protein Pilot ${ }^{\mathrm{TM}}$ software. The MASCOT algorithm was used to search the generated peaks lists against the NCBI non-redundant database and the Uniprot non-redundant database, selected for rodents, E.coli or Rattus rattus. Other search parameters allowed for one missed enzyme cleavage, fixed carbamidomethyl modification, variable modification by methionine oxidation, $\mathrm{MS} / \mathrm{MS}$ fragment tolerance of $\pm 0.1 \mathrm{Da}$, monoisotopic masses, precursor tolerance of $\pm 0.05 \mathrm{Da}$ and a +1 peptide charge. When a significant score was given this given resulted in a positive identification. 


\subsection{Recombinant protein expression}

\subsubsection{Tissue and methodologies}

\subsubsection{Animal tissue}

Liver and kidney tissue was removed from one male and one female laboratory Norway rat, one male and one female wild Norway rat and two male and two female wild ship rats. These tissue samples were used to extract RNA in method 2.5.3.

\subsubsection{Primers used for PCR and DNA sequencing}

The sequences used are indicated below:

Forward primer:

GGATCCGCTGTTGCTGCTGCTGC

Reverse primer:

AAGCTTACCTCGGGCCTTGAGAC

\subsubsection{E.coli cells for protein expression}

For protein expression, BL21(DE3)pLysS (Novagen) cells with pET23b Vector containing MUP were the first to be used. An attempt at MUP cloning and protein production originally yielded minimal levels. Changes to the large scale expression steps and the purification steps were attempted with no improvement: these will be discussed further in section 2.5.12. Subsequently re-ligating MUP DNA with a pET23b Vector, resolved the problem of generating a sufficient yield. To further increase the amount of MUP produced, Rosetta-gami B(DE3)pLysS cells (Novagen) were also used. These cells are designed to assist in the formation of disulfide bonds, which can assist in the stability of yielding a protein in a folded state.

\subsubsection{Identifying target MUPs using BLAST database}

A protein BLAST (NCBI) was run, using a rat database, on the protein sequence of mouse darcin located under accession numbers NP_001012323/XP_355497. A rat protein sequence was identified called MUP4 (accession number NP_942079.1): this 
had the most sequence identities with Darcin compared with other Norway rat MUPs. It was found to have $90 \%$ Query coverage, a (E)-value of $5 \mathrm{e}^{-77}$, and $69 \%$ identities.

\subsubsection{RNA extraction}

Total RNA was extracted from rat liver and kidney tissue. The tissues were weighed and $1 \mathrm{~mL} / 100 \mathrm{mg}$ Trizol reagent was added for the extraction. The tissues were then homogenized using an ultraturrex (IKA®). Using a pipette, $1 \mathrm{~mL}$ of sample was transferred to a sterile centrifuge and incubated for $5 \mathrm{~min}$. Chloroform $(0.2 \mathrm{~mL} / \mathrm{mL}$ Trizol) was added and each tube shaken vigorously by hand for $15 \mathrm{sec}$, followed by incubation at room temperature for 2-3 min. The samples were then centrifuged at $4{ }^{\circ} \mathrm{C}$ for $15 \mathrm{~min}$ at $12,000 \mathrm{x} \mathrm{g}$. This led to the samples each being separated into 3 phases. The colorless upper aqueous phase, containing the RNA, was transferred to a new centrifuge tube. Isopropanol was then added and the samples incubated at room temperature for $10 \mathrm{~min}$, followed by centrifugation at $12,000 \mathrm{x} \mathrm{g}$ for $10 \mathrm{~min}$ at $4^{\circ} \mathrm{C}$. The supernatant was removed, leaving a RNA pellet. The pellet was washed with $70 \%$ ethanol, vortexed, and centrifuged at 7,500 $\mathrm{xg}$ for $5 \mathrm{~min}$ at $4^{\circ} \mathrm{C}$. After removal of the ethanol, the centrifuge tubes were inverted and left to dry for $15 \mathrm{~min}$. The RNA pellets were then dissolved in $50 \mu \mathrm{L}$ DEPC and incubated for $10 \mathrm{~min}$ on ice. Using a spectrophotometer, the concentration of RNA was determined, using TE buffer (10 mM tris, $1 \mathrm{mM}$ EDTA, $\mathrm{pH} 8.0$ ) to re-suspend the samples. RNA samples were stored at -20 ${ }^{\circ} \mathrm{C}$ until use.

\subsection{4 cDNA synthesis}

The protocol used herein was suitable for converting between $0.1 \mathrm{pg}$ and $5 \mathrm{mg}$ of total RNA into first strand cDNA. In this study, up to $5 \mu \mathrm{g}$ of total RNA, $50 \mu \mathrm{M}$ oligo $(\mathrm{dT})_{20}$, annealing buffer, and RNase free water were combined in a $0.2 \mathrm{~mL}$ thin walled PCR tube on ice. The sample was then incubated in a thermal cycler at $65^{\circ} \mathrm{C}$ for $5 \mathrm{~min}$, placed on ice for $1 \mathrm{~min}$, and the contents then recovered by $2 \mathrm{sec}$ centrifugation. Added to the sample tube were 2X First-Strand Reaction Mix and Superscript III/RNaseOUT Enzyme Mix. The sample was mixed and collected after a $2 \mathrm{sec}$ centrifugation. The sample was incubated for $50 \mathrm{~min}$ at $50^{\circ} \mathrm{C}$, then terminated at $85^{\circ} \mathrm{C}$ for $5 \mathrm{~min}$, and then chilled on ice. The resulting cDNA was stored at $-20^{\circ} \mathrm{C}$ until further use. 


\subsubsection{PCR}

\subsubsection{General PCR set- up}

A master mix of all reagents (see below) excluding the cDNA and Taq was prepared:

\begin{tabular}{lll}
\hline Reagent & 1 x reaction & Negative control \\
\hline $\mathrm{ddH}_{2} \mathrm{O}$ & $40.5 \mu \mathrm{L}$ & $41.5 \mu \mathrm{L}$ \\
$10 \times$ PCR5 & $5 \mu \mathrm{L}$ & $5 \mu \mathrm{L}$ \\
dNTPs $(10 \mathrm{mM})$ & $1 \mu \mathrm{L}$ & $1 \mu \mathrm{L}$ \\
Forward primer & $1 \mu \mathrm{L}$ & $1 \mu \mathrm{L}$ \\
Reverse primer & $1 \mu \underline{\mathrm{L}}$ & $1 \mu \mathrm{L}$ \\
cDNA & $1 \mu \mathrm{L}$ & - \\
Taq polymerase & $0.5 \mu \mathrm{L}$ & $0.5 \mu \mathrm{L}$ \\
\hline Total & $50 \mu \mathrm{L}$ & $50 \mu \mathrm{L}$ \\
\hline
\end{tabular}

The cDNA was added to individual centrifuge tubes. Taq was added to the master mix, which was then added into each centrifuge tube containing the cDNA. Tubes were then subjected to PCR under the following conditions:

\begin{tabular}{lll}
\hline Temp $\left({ }^{\circ} \mathbf{C}\right)$ & Time & Number of cycles \\
\hline 94 & $2 \mathrm{~min}$ & $\mathrm{x} 1$ \\
94 & $10 \mathrm{sec}$ & \\
55 -annealing & $15 \mathrm{sec}$ & $\mathrm{x} 40$ \\
72 & $30 \mathrm{sec}$ & \\
72 & $7 \mathrm{~min}$ & $\mathrm{x} 1$ \\
15 & Hold & \\
\hline
\end{tabular}

\subsubsection{PCR gel}

PCR products were checked by gel electrophoresis, with a GeneRuler 1kb DNA Ladder (Thermo Scientific). Samples were added to 6x RNA loading dye on a 1.5\% Seakem LE agarose gel made in 1x TAE buffer. The DNA bands were then directly cut from the gel, and purified using the Qiagen gel extraction kit as described below. 


\subsubsection{Gel extraction}

Once the sample had been run through the gel, bands of interest were identified under UV light and then cut out using small sharp sterile blades, and transferred into $1.5 \mathrm{~mL}$ centrifuge tubes. The Qiagen Gel (QG) extraction kit was used to extract the DNA from agarose gels. The isolated gel pieces were weighed and three volumes of QG buffer was then added, and the mixture left to incubate for $10 \mathrm{~min}$ at $50^{\circ} \mathrm{C}$. Isopropanol (one volume) was added to each gel sample which was then transferred to a gel extraction column. The column was centrifuged at $14,000 \times \mathrm{g}$ for $1 \mathrm{~min}$. The column was then washed with $500 \mu \mathrm{L}$ QG buffer and spun for 1 min. Thereafter, PE buffer, $(750 \mu \mathrm{L})$ was added, and the column incubated for $4 \mathrm{~min}$ at room temp and subsequently spun at $14,000 \mathrm{x} g$ for $1 \mathrm{~min}$. The supernatant was discarded and column spun again for $1 \mathrm{~min}$. The column was then put into a centrifuge tube, $30 \mu \mathrm{L}$ elution buffer added and incubated at room temperature for $1 \mathrm{~min}$. Finally, the column was spun for $1 \mathrm{~min}$ to elute DNA. The DNA was then stored in a centrifuge tube at $-20^{\circ} \mathrm{C}$.

\subsubsection{Cloning}

\subsubsection{Ligation of PCR product and pGEM-T Easy Vector}

In a $1.5 \mathrm{~mL}$ centrifuge tube, $2 \mathrm{X}$ Ligase (manufacturer), 10X buffer (manufacturer), pGEM®-T Easy Vector ( 50 ng), gel extracted DNA, and T4 DNA ligase (manufacturer) were combined and mixed gently by pipetting and then incubated at room temperature for $2 \mathrm{~h}$.

\subsubsection{Transformation of DH5 $\alpha$ cells}

Falcon tubes $(15 \mathrm{~mL})$ were pre-chilled on ice. Gently mixed DH5 $\alpha$ competent cells (Invitrogen) were added to each tube with 1-5 $\mu \mathrm{L}$ of ligated DNA and incubated at room temperature for $30 \mathrm{~min}$. The cells were then heat-shocked at $37^{\circ} \mathrm{C}$ for $2 \mathrm{~min}$, followed by cooling on ice for $2 \mathrm{~min}$. To each tube, $0.95 \mathrm{~mL}$ Lysogeny broth (LB) was added and then placed in a shaking incubator set at $225 \mathrm{rpm}$ for $1 \mathrm{~h}$ at $37^{\circ} \mathrm{C}$. At this point, $50 \mu \mathrm{L}$ of 2\% X-gal was added to agar plates, containing Ampicillin (Amp), and left to soak for at least $20 \mathrm{~min}$. The tubes were then spun for $5 \mathrm{~min}$ in a centrifuge 5810R (Global science, NZ). The supernatant was then discarded and the residual LB $(\sim 10 \mu \mathrm{L})$ was used to re- 
suspend the pellet. The cells were then pipetted onto an agar plate containing Amp and using a spreader, transferred to a second plate. Plates were then left with media on the bottom for 1-2 $\mathrm{h}$ to allow the cells to soak-in. Thereafter, the plates were placed bottom up in a $37^{\circ} \mathrm{C}$ incubator overnight.

\subsubsection{Miniprep}

DNA purification of the transformed cells was carried out using the QIAprep spin miniprep kit as per manufacturer's instructions. For each preparation, a $10 \mathrm{~mL}$ LB culture, including antibiotic was grown overnight. The following day the bacterial cell cultures were pelleted by centrifugation at $13,000 \mathrm{x}$ g for $10 \mathrm{~min}$. The pellets were resuspended in Buffer $\mathrm{P} 1$ by pipette and transferred to a $1.5 \mathrm{~mL}$ centrifuge tube. Subsequently, the lysis buffer P2 $(250 \mu \mathrm{L})$ was added and the capped tube inverted gently six times and then left to incubate at room temperature for $5 \mathrm{~min}$. Thereafter, the N3 neutralisation buffer was added and sample was again inverted six times, followed by centrifugation at $13,000 \mathrm{x}$ g for $10 \mathrm{~min}$. The resulting supernatants were applied to QIAprep columns and centrifuged for $1 \mathrm{~min}$. The flow through was discarded and Buffer PB was added and sample centrifuged at $13,000 \mathrm{x} \mathrm{g}$ for $1 \mathrm{~min}$ at room temperature. The column was washed again with Buffer PE and centrifuged for $1 \mathrm{~min}$, followed by an additional $1 \mathrm{~min}$ centrifugation to remove any residual buffer. The column was placed in a centrifuge tube, elution buffer was added, and then the column was left standing for $1 \mathrm{~min}$ before centrifugation at $13,000 \mathrm{x} \mathrm{g}$ for $1 \mathrm{~min}$ at room temperature. The resulting DNA samples were stored at $-20^{\circ} \mathrm{C}$ until further use.

\subsubsection{Sequencing}

The DNA obtained from the mini preps was sent to The University of Waikato DNA sequencing facility along with the previously designed MUP4 primers. 


\subsubsection{Restriction digest}

Mini prep DNA was used to perform a restriction digest which was set up with the following solution composition shown below:

\begin{tabular}{ll}
\hline Solution & Volume \\
\hline Plasmid DNA & $10 \mu \mathrm{g}$ \\
Restriction digest buffer & $2 \mu \mathrm{L}$ \\
Restriction enzyme & $2 \mu \mathrm{L}$ \\
$\mathrm{dH}_{2} \mathrm{O}$ & To a total of $10 \mu \mathrm{L}$ \\
\hline
\end{tabular}

The samples were digested at $37^{\circ} \mathrm{C}$ for at least $2 \mathrm{~h}$. The reaction was stopped by heating the samples to $65{ }^{\circ} \mathrm{C}$ for $10 \mathrm{~min}$. To prepare the samples to be run on a $1.5 \%$ agarose gel (1.5 g agarose, $100 \mathrm{~mL}$ TAE buffer), $6 \mu \mathrm{L}$ of loading dye $(6 \mathrm{x})$ was added to each sample.

\subsubsection{Gel extraction}

Bands containing MUP DNA were extracted using the previously described protocol (see section 5.5.6).

\subsubsection{Sub cloning (expression)}

\subsubsection{Ligation of gel extracted DNA and pET $23 \mathrm{~b}(+)$ or pQE-30 Vector}

The same protocol as used in the previous ligation (see section 2.5.7.1) was used for this ligation, however the vectors used were pET-23b(+) and pQE-30, with gel extracted DNA.

\subsubsection{Transformation of DH5a, BL21(DE3)pLysS and Rosetta-gami B(DE3)pLysS cells}

The transformation protocol was the same as stated previously (2.6.7.2). The initial transformation was done with $\mathrm{DH} 5 \alpha$ cells, followed by transformation with expressing cells BL21(DE3)pLysS or Rosetta-gami 2(DE3)pLysS once ligation was confirmed by 
restriction digest of mini prep DNA, using the protocols previously described (see section 2.5.8).

\subsubsection{Small scale protein expression}

One colony of transformed BL21(DE3)pLysS or Rosetta B(DE3)pLysS E. coli cells was added to a glass vial containing $10 \mathrm{~mL}$ of LB with $50 \mathrm{mg} / \mathrm{mL}$ ampicillin (Amp) and grown overnight in a $37^{\circ} \mathrm{C}$ shaking incubator at $250 \mathrm{rpm}$. The following day, $1 \mathrm{~mL}$ of the cell culture was added to a $15 \mathrm{~mL}$ falcon tube with $19 \mathrm{~mL}$ fresh $\mathrm{LB}$. This culture was then grown at $37^{\circ} \mathrm{C}$ for $3 \mathrm{~h}$ with shaking at $250 \mathrm{rpm}$, after which $5 \mathrm{~mL}$ of culture was removed, resuspended in $1 \mathrm{~mL} 50 \mathrm{mM}$ tris-HCL pH 8.0, and stored at $-20^{\circ} \mathrm{C}$. To the remaining cell culture, $0.1 \mathrm{M}$ IPTG was added and grown for a further $3 \mathrm{~h}$ at $37^{\circ} \mathrm{C}$, $250 \mathrm{rpm}$. After this, the culture was centrifuged, the resulting pellet resuspended, and stored at $-20^{\circ} \mathrm{C}$. Confirmation of MUP protein expression from the small scale expression was visualized by SDS-PAGE as previously described (2.3.1.3).

\subsubsection{Large scale protein expression}

\subsubsection{Protein preparation}

One colony of transformed E. coli cells were added to $10 \mathrm{~mL} \mathrm{LB}$ broth with Amp, and incubated overnight in a $37^{\circ} \mathrm{C}$ shaking incubator set at $250 \mathrm{rpm}$. The next day, the overnight incubation was inoculated with $500 \mathrm{~mL} \mathrm{LB}$ and Amp and grown under the same conditions until the optical density $\left(\mathrm{OD}_{600}\right)$ of the cells reached $\sim 0.6$. Following this, $5 \mathrm{~mL}$ of isopropyl $\beta$-D-1-thiogalactopyranoside (IPTG) was added to each flask to induce expression. These cells were incubated for a further $5 \mathrm{~h}$ at $37^{\circ} \mathrm{C}$ at $250 \mathrm{rpm}$. Alternatively, the Rosetta B(DE3)pLysS cells were induced for $16.5 \mathrm{~h}$ at $25^{\circ} \mathrm{C}$ at 250 rpm in an attempt to produce soluble protein. These cells were then centrifuged at 1399 $\mathrm{x} \mathrm{g}$ for $15 \mathrm{~min} 20^{\circ} \mathrm{C}$ followed by re-suspension in $30 \mathrm{~mL}$ of $0.1 \mathrm{M} \mathrm{NaPO}_{4} / 0.01 \mathrm{M}$ tris$\mathrm{HCl} \mathrm{pH}$ 8. The samples were stored at $-20^{\circ} \mathrm{C}$ until further use.

\subsubsection{Solubilisation of inclusion bodies}

To determine whether the synthesised protein was soluble or insoluble, $10 \mathrm{mg} / \mathrm{mL}$ of lysozyme was added to each cell culture. The cell suspensions were then mixed and incubated at room temperature for $30 \mathrm{~min}$. Following this, $0.4 \mathrm{~mL}$ of $10 \%$ Triton $\mathrm{X} 100$ 
$/ 10 \mathrm{~mL}$ was added to the samples which were then placed on ice. Thereafter, the bacterial cells were lysed using either a French press or a cell sonicator, with the French press being the preferred method. Subsequently, the cells were centrifuged at $22718 \mathrm{xg}$ for $15 \mathrm{~min}$ (Sorvall SS34 rotor, corex tubes). The resulting supernatants (i.e. the soluble protein fraction) were stored at $-20^{\circ} \mathrm{C}$. The cell pellets were washed by resuspending them in $15 \mathrm{~mL} 0.1 \mathrm{M} \mathrm{NaPO}_{4} / 0.01 \mathrm{M}$ tris- $\mathrm{HCl}, \mathrm{pH} 8$, and centrifugation at $22718 \mathrm{x} \mathrm{g}$ for $15 \mathrm{~min}$. The resulting supernatant was discarded and $15 \mathrm{~mL}$ of $8 \mathrm{M}$ urea in $0.1 \mathrm{M}$ $\mathrm{NaPO}_{4} / 0.01 \mathrm{M}$ tris- $\mathrm{HCl}, \mathrm{pH} 8$, was added to the pellet and left at room temperature to shake for $1 \mathrm{~h}$ on a rocking table. The samples were then centrifuged at $22718 \mathrm{x}$ g for 10 min, the supernatant (the insoluble protein fraction) removed, and then stored at $-20^{\circ} \mathrm{C}$.

Variations of this protocol were used when BL21 cells failed to produce significant amounts of MUP protein. These included the addition of lysis buffer $\left(50 \mathrm{mM} \mathrm{NaH}_{2} \mathrm{PO}_{4}\right.$, $300 \mathrm{mM} \mathrm{NaCl}, 10 \mathrm{mM}$ Imidazole) to the cell cultures before being using the French press, instead of using lysozyme. Also attempted was the addition of Complete Protease Inhibitor Tablets (Roche) or DNAse1 (Thermo Scientific) to the lysed cell cultures. Additionally, passing the cell culture through a $0.25 \mu \mathrm{M}$ filter was tried after French pressing. None of the variations in protocol affected the protein production.

\subsubsection{Column purification}

The proteins were purified using the QIA express Ni-NTA Protein Purification System (Ni-NTA Superflow, Quiagen, USA). NiNTA beads were first centrifuged at $100 \mathrm{xg}$ for $1 \mathrm{~min}$ and the supernatant removed. The beads were then washed twice with $1 \mathrm{~mL}$, of $0.1 \mathrm{M} \mathrm{NaPO}_{4} / 0.01 \mathrm{M}$ tris- $\mathrm{HCl}, \mathrm{pH} 8$, for the soluble fraction or $1 \mathrm{~mL}$ of $8 \mathrm{M}$ Urea in $0.1 \mathrm{M} \mathrm{NaPO}_{4} / 0.01 \mathrm{M}$ tris- $\mathrm{HCl}, \mathrm{pH} 8$, for the insoluble fraction. The beads were then centrifuged at $100 \mathrm{x} \mathrm{g}$ for $2 \mathrm{~min}$, and the resulting supernatant discarded. The beads were added to the protein samples and left overnight at $4^{\circ} \mathrm{C}$ on a rotator. The next day, the samples were spun down at $1000 \mathrm{x} \mathrm{g}$ for $5 \mathrm{~min}$. Thereafter, the supernatant was removed and the beads were re-suspended in $10 \mathrm{~mL} 8 \mathrm{M}$ urea in $0.1 \mathrm{M} \mathrm{NaPO}_{4} / 0.01 \mathrm{M}$ tris- $\mathrm{HCl}$, pH 8 buffer. Five $\mathrm{mL}$ columns were washed with $3 \mathrm{~mL}$ of a $0.1 \mathrm{M} \mathrm{NaPO}_{4} /$ $0.01 \mathrm{M}$ tris- $\mathrm{HCl}, \mathrm{pH} 8$, buffer and a syringe was used to remove any air bubbles from each column. The sample containing the beads was then loaded onto the column and washed with $5 \mathrm{~mL}$ buffer. To remove any loosely bound proteins, the column was again 
washed with $0.1 \mathrm{M} \mathrm{NaPO}_{4} / 0.01 \mathrm{M}$ tris-HCl, $\mathrm{pH}$ 8, buffer containing $10 \mathrm{mM}$ Imidazole and then $20 \mathrm{mM}$ Imidazole. Subsequently, the putative MUP protein(s) was eluted with $250 \mathrm{mM}$ Imidazole in $0.1 \mathrm{M} \mathrm{NaPO}_{4} / 0.01 \mathrm{M}$ tris-HCL, $\mathrm{pH} 8$, buffer. To solubilise the purified protein, on-column refolding was attempted with MUP purified from BL21 cells. This involved washing a loaded column with decreasing amounts of urea, from 6 to- $0 \mathrm{M}$ in either $0.1 \mathrm{M} \mathrm{NaPO}_{4} / 0.01 \mathrm{M}$ tris-HCL, $\mathrm{pH} 8$, or $55 \mathrm{mM}$ tris $\mathrm{pH} 8.2,264 \mathrm{mM}$ NaCL, $11 \mathrm{mM} \mathrm{KCL}, 1.1 \mathrm{mM}$ EDTA buffer, and $1 \mathrm{M}$ imidazole. This was followed by a wash with $20 \mathrm{mM}$ Imidazole in buffer with no urea. Finally protein was eluted with 250 $\mathrm{mM}$ Imidazole in the appropriate buffer.

\subsubsection{Bicinchoninic acid assay (BCA assay)}

The BCA technique (Thermo Scientific Pierce BCA Protein Assay Kit) was used to quantify the concentration of purified MUP samples before dialysis. The protocol used was as per the instructions supplied by the manufacturer. This involved preparing a set of protein standards, using a stock solution of BSA as the reference protein to cover a range of concentrations from $0-2000 \mu \mathrm{g} / \mathrm{mL}$. Thereafter, $10 \mu \mathrm{L}$ of each standard or unknown sample was added into wells in a microtiter plate, with each sample being tested in duplicate. After combining 50 parts of Reagent A with 1 part of reagent B, 200 $\mu \mathrm{L}$ of working reagent was added to each well. The microtiter plates containing the samples were mixed for $30 \mathrm{sec}$ on a microtiter plate shaker, followed by a $1 \mathrm{~h}$ incubation at $37^{\circ} \mathrm{C}$. After this, the absorbance of each well was read at $562 \mathrm{~nm}$ with a MixMate microtiter plate reader (Eppendorf). After determining a standard curve from the results, the protein concentration was found. The recommended maximum concentration of urea used for efficiency of this kit was $3 \mathrm{M}$, however some of the samples used in this thesis contained $8 \mathrm{M}$ urea in order to maintain the protein in solution, therefore, the accuracy of some of the samples could not be guaranteed. Attempts at dissolving BSA in 8M urea proved unsuccessful.

\subsubsection{Dialysis}

A dialysis procedure was used to transfer the purified protein(s) into a more suitable buffer for further study. Dialysis tubing was soaked for $1 \mathrm{~h}$ in the selected buffer. Thereafter, the purified protein sample was added to the dialysis tube, sealed and left 
overnight in $200 \mathrm{~mL}$ (per dialysis tube) buffer at $4^{\circ} \mathrm{C}$ with constant magnetic mixing. Buffers that were used for dialysis of purified MUP from BL21(DE3)pLysS cells included:

○ $\quad 0.1 \mathrm{M} \mathrm{NaPO}_{4} / 0.01 \mathrm{M}$ Tris-HCL pH 8

○ PBS, pH 7.4

○ $55 \mathrm{mM}$ Tris pH 8.2, $2.64 \mathrm{mM} \mathrm{NaCl}, 11 \mathrm{mM} \mathrm{KCl}, 1.1 \mathrm{mM}$ EDTA, $550 \mathrm{mM}$ L-Arginine.

○ $55 \mathrm{mM}$ Tris pH 8.2, $264 \mathrm{mM} \mathrm{NaCl}, 11 \mathrm{mM} \mathrm{KCl}, 550 \mathrm{mM}$ GdnHCL, 1.1 mM EDTA.

○ $55 \mathrm{mM}$ Tris $\mathrm{pH} 8.2,264 \mathrm{mM} \mathrm{NaCl}, 11 \mathrm{mM} \mathrm{KCl}, 1.1 \mathrm{mM}$ EDTA

○ $3 \mathrm{M}$ urea

For the Rosetta Bs(DE3)pLysS cell derived proteins, only PBS and 0.1 $\mathrm{M} \mathrm{NaPO}_{4} / 0.01$ M Tris-HCL pH 8 were used for the dialysis step. 


\section{Results}

\subsection{Detection of putative chemical attractants in rat urine: volatile organic reagents and proteins.}

From preliminary experiments to validate procedures using the GC/MS system, the presence of 2-sec-butyl-4,5-dihydrothiazole was identified in urine from BALB/c and B6 mice; this compound has previously been reported to be a male-specific chemical attractant (Roberts et al, 2010). The results from this validation experiment are shown in Appendix 1. In addition, from preliminary studies to validate a one-dimensional (1D) gel electrophoresis system, MUP proteins of the appropriate size were identified in the urine of both male and female BALB/c and B6 mice; MUP proteins are also thought to act as chemical attractants. The results from this validation experiment are shown in Appendix 2. From the experimental protocols established for mouse urine, more extensive studies using the aforementioned techniques and recombinant MUP protein synthesis were undertaken using urine from both Norway and ship rats, the latter being the target species of interest described in this thesis.

\subsubsection{Analysis of rat urine by Gas chromatography/Mass spectrometry}

\subsubsection{Identification of male-specific compounds in urine from Norway and ship rats}

These data are summarized in Table 1. Analyses of the volatile compositions of three pooled samples from each of four male and four female laboratory Norway rats (Rattus norvegicus) showed five male-specific compounds. In addition, one wild male Norway rat sample contained six male- specific compounds, three of which could be tentatively identified using mass spectral fragmentation patterns and library matching. The compound tentatively identified as 4-methyl heptan-3-one was found in both the laboratory and wild Norway male samples. Analyses of samples from five wild ship rats (R. rattus) identified seven predominantly male-specific peaks, with six tentatively identified by mass spectrometry. In wild ship rats, 2,5,5-trimethylheptane was the only compound that was strictly male-specific. Nevertheless, although the others such as 
benzeneacetaldehyde, 2,6,6-trimethyl-2-cyclohexane-1,4-dione, 2(10)-pinen-3-one, 4phenyl-2-butanone and 2,4,5-trioxoimidazolidine were present in females, they were found at very low levels.

\begin{tabular}{|c|c|c|}
\hline Rat type & Compound & $\begin{array}{l}\text { Retention } \\
\text { time (min) }\end{array}$ \\
\hline \multicolumn{3}{|c|}{ Laboratory Norway } \\
\hline & 3,3-dimethyl pentan-2,4-diol & 7.91 \\
\hline & 4-methyl heptan-3-one & 8.27 \\
\hline & 4-nonanone & 9.53 \\
\hline & 3-ethyl pentan-2,4-dione & 10.50 \\
\hline \multicolumn{3}{|c|}{ Wild Norway } \\
\hline & 3-ethyl pentan-2-one & 3.94 \\
\hline & 4 methyl heptan-3-one & 8.15 \\
\hline & Not determined & 9.54 \\
\hline & 2,4-pentanedione,3-ethyl & 10.35 \\
\hline & Not determined & 14.78 \\
\hline & Not determined & 16.00 \\
\hline \multicolumn{3}{|l|}{ Wild ship } \\
\hline & Not determined & 2.33 \\
\hline & Benzeneacetaldehyde & 8.72 \\
\hline & 2,6,6-trimethyl-2-cyclohexane-1,4-dione 86 & 11.26 \\
\hline & 2(10)-pinen-3-one & 11.68 \\
\hline & Heptane 2, 5,5-trimethyl & $13.65^{*}$ \\
\hline & 4-phenyl,2-butanone & 15.41 \\
\hline & 2,4,5-troxoimidazolidine & 15.64 \\
\hline
\end{tabular}

Table 1 Volatile compounds identified by GC-MS in urine samples from male laboratory Norway rats (one pool from 3 animals), one wild Norway rat, and five individual male wild ship rats. All compounds were identified based upon comparison with mass spectral libraries. All but one of the male ship rat compounds $(* 2,5,5$-trimethyl-heptane $)$ were present in one female sample. 


\subsubsection{The presence of 2- and 4-heptanone in rat urine}

The presence of two compounds of interest, 2-heptanone and 4-heptanone, was investigated in the urine of two different rat species. Urine samples of both male and female laboratory Norway rats contained 2-heptanone and 4-heptanone, with the male rat urine containing higher levels of these compounds than the female (Figure 4). Wild Norway rat urine of both sexes $(\mathrm{N}=1$ each) contained 2-heptanone, with the male containing higher levels. However, only the male urine sample contained 4-heptanone (Figure 5). Male ship rat urine contained higher levels of both 2- and 4-heptanone than females (Figure 6). Statistical comparisons for 2-heptanone, 4-heptanone, and dimethyl sulfone showed no significant differences based on gender. 


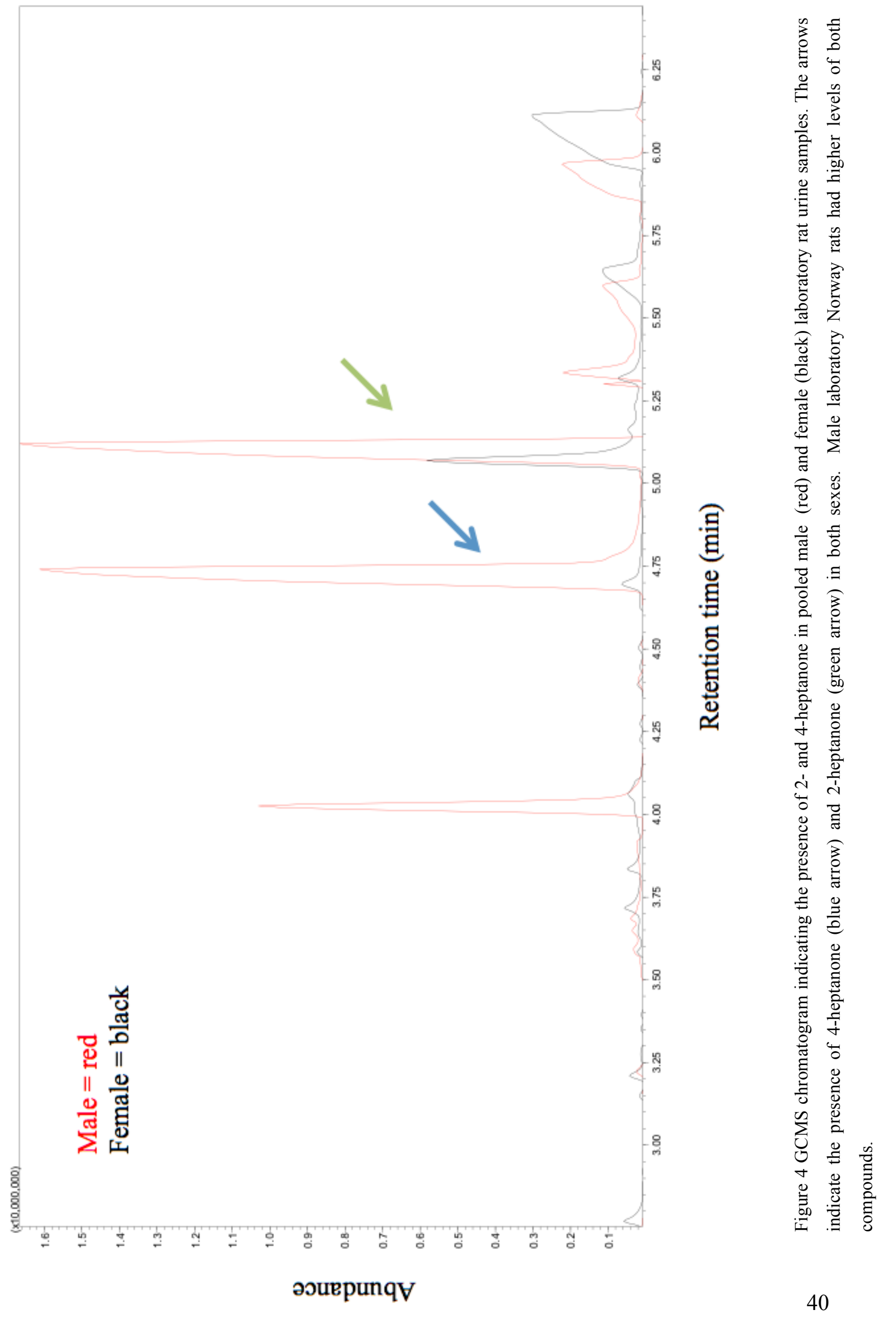




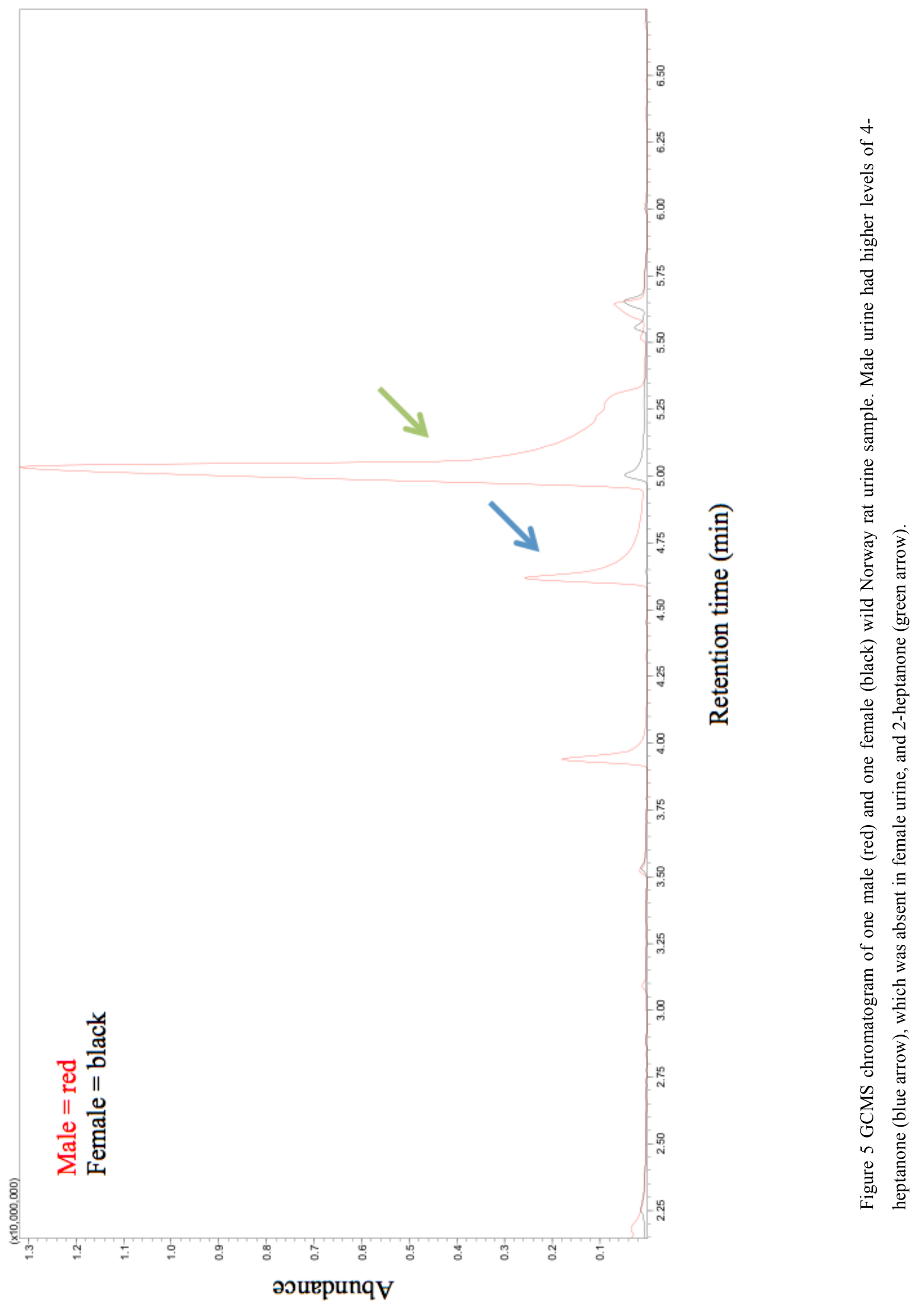



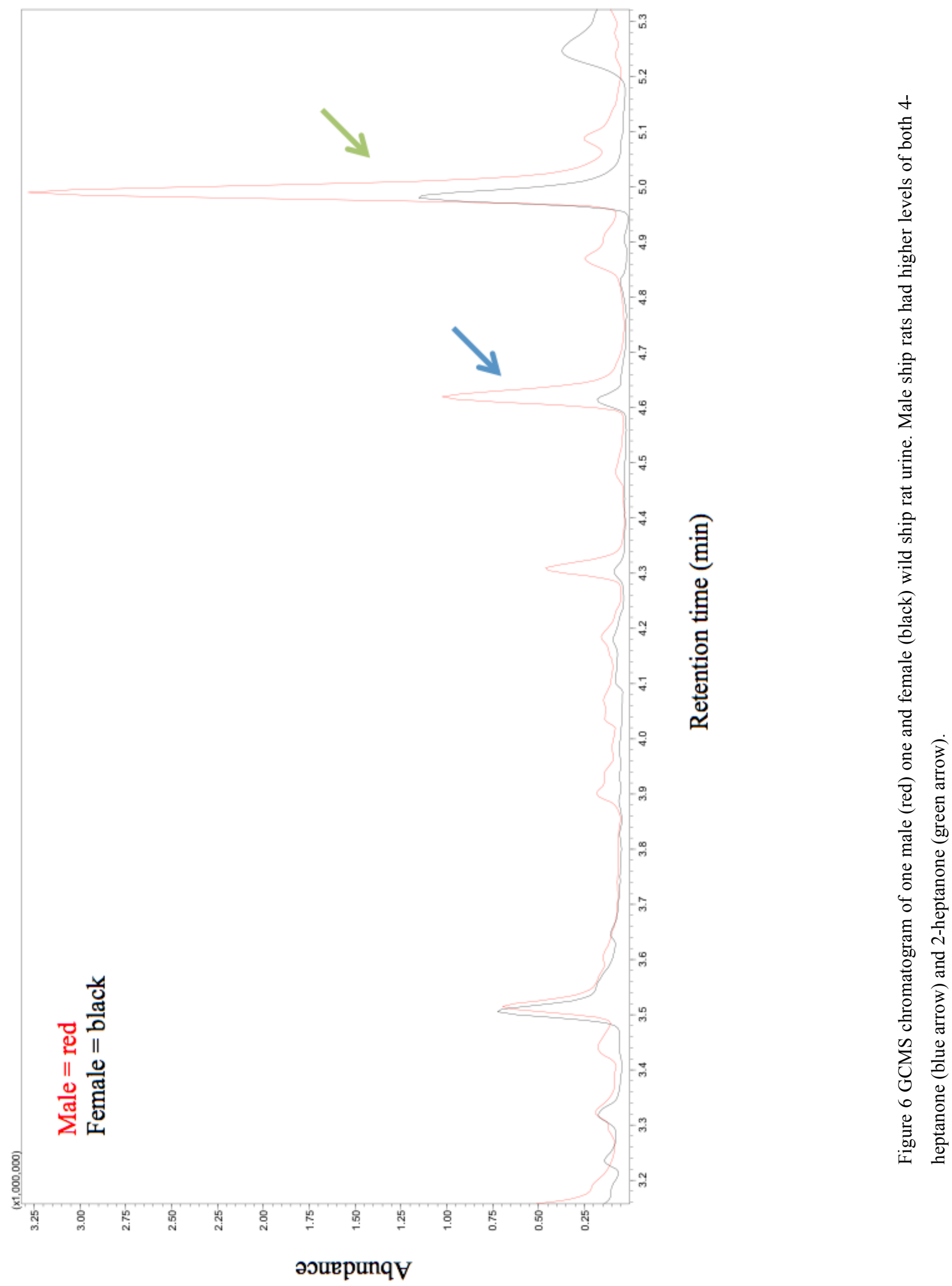


\subsubsection{Analysis of rat urine by gel electrophoresis}

\subsubsection{One dimensional (1D) gel}

From analyses of urine from Norway and ship rats, all, regardless of sex or species, contained MUP-sized proteins (17-23 kDa) (Figure 7). The range of proteins in individual wild rats $(\mathrm{N}=14)$ was more variable than that for the laboratory rats $(\mathrm{N}=8)$. The differences in the concentrations of the MUP-sized proteins between male and female rats were not determined as no method of quantification proved to be successful. Some urine from both female laboratory Norway and female wild Norway rat samples were barely visible on their corresponding gels. This may have been a consequence of being unable to quantify protein levels. The presence of MUPs in laboratory rat and wild ship rat urine was confirmed by Western blotting (Figure 8). In summary, the results of $1 \mathrm{D}$ electrophoresis and Western blot experiments indicate that male rat urine contains proteins not present in female urine. 

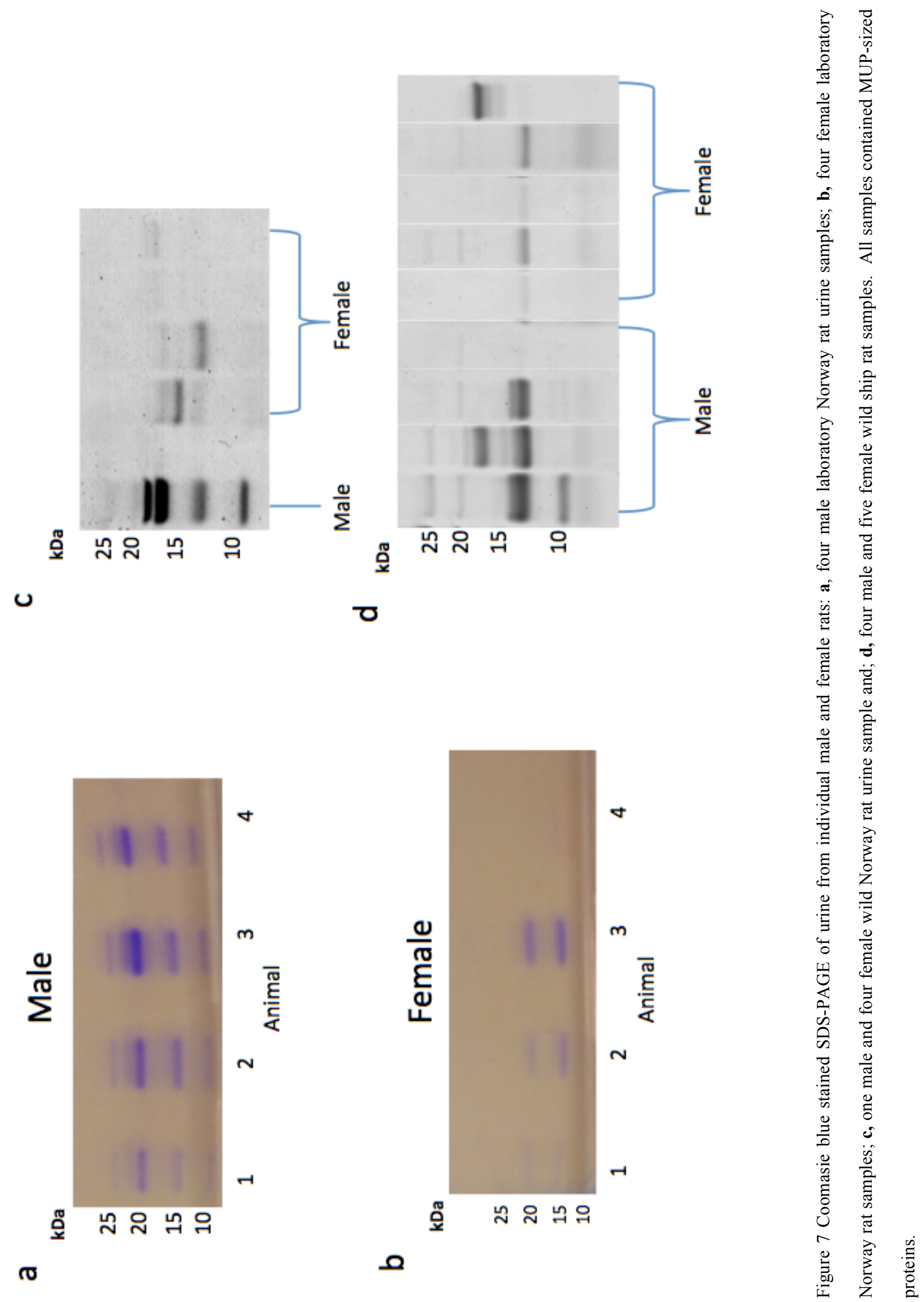


\section{kDa}

25

20

15

10
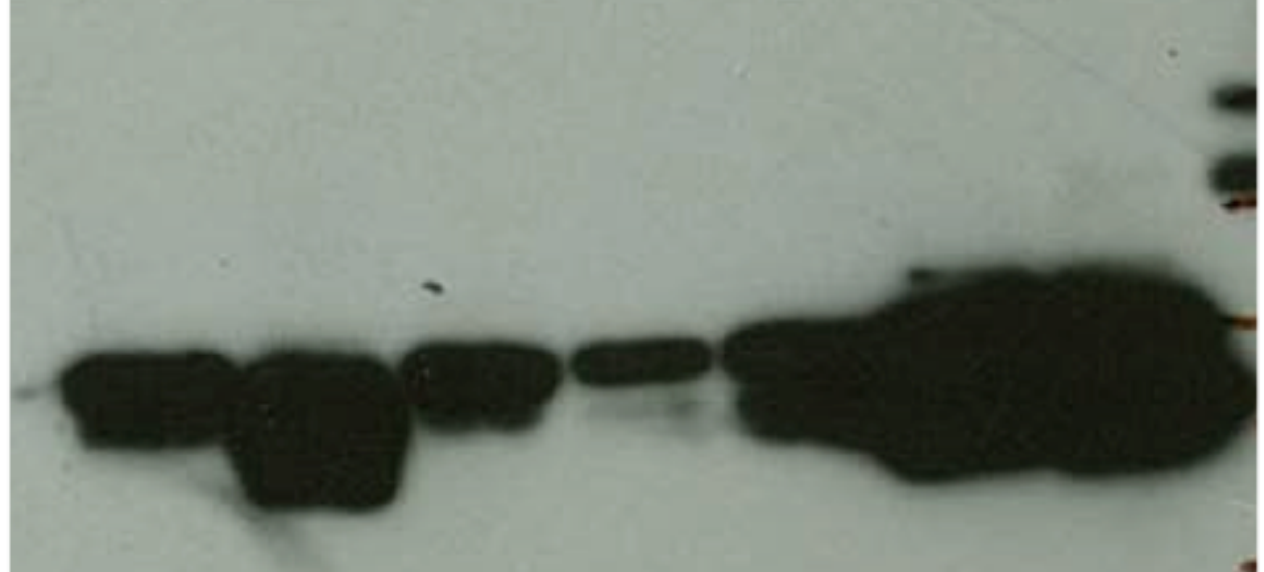

\section{$\begin{array}{cccc}1 & 2 & 3 & 4 \\ & & & \text { Lane }\end{array}$}

Figure 8 Western blot of rat urine samples, using anti-MUP antibody: Lanes 1-3 represents urine from three male wild ship rats; lane 4 urine from one female wild ship rat and; lanes 5-7: urine from three male laboratory Norway rats. 


\subsubsection{Analysis of rat urine by two dimensional (2D) gel electrophoresis}

2D analysis of fractionated rat urine was performed to enable the resolution of proteins that were similar in size. These gels showed an array of proteins present in both sexes, with males appearing to express a wider variety of proteins than females. However, as mentioned earlier, the gender difference was not validated, as the protein concentrations were not determined prior to loading. For both male and female samples, the gels showed similar results when replicated (see appendix 3). Both laboratory Norway rats (Figure 9) and wild ship rats (Figure 10) express MUP-sized proteins. The proteins were analysed further by MALDI-TOF/TOF, with some being identified by a significant score match to the selected databases (Table 2). No spots could be identified with either type of analyses in the female laboratory rat sample. The overall spectra for many spots was poor with no significant matches found. Spectra for spots where there was no significant score and considered likely to be MUPs, were analysed manually (Table 2): these peptide fragments (see appendix 4) were matched against a list of predicted peptide fragments for all known MUPs (see appendix 5). MUP proteins were tentatively identified using this method in Norway male urine, and both male and female ship rat urine. 
동

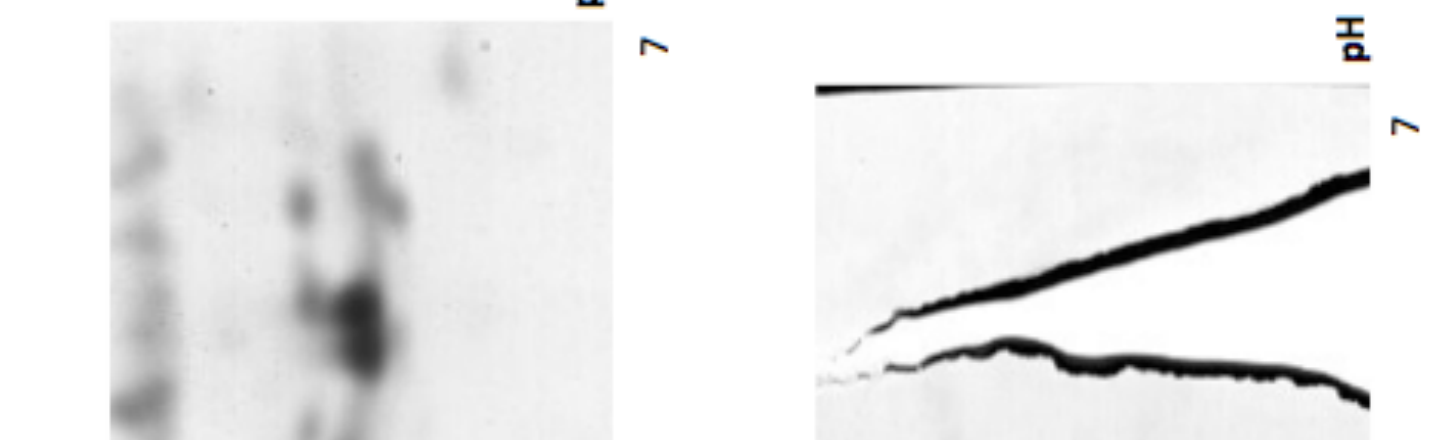

$\frac{0}{10}$

$\pi$

ฌ๊

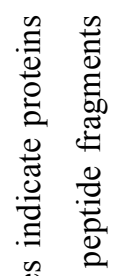

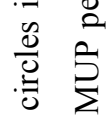

Ð

壱

के

.

क 3

$\cong$ 릉

: :

8

ㅍำ

3

导

常

$\stackrel{0}{\stackrel{0}{0}}$

.

范

产 表 $\frac{0}{0}$

ज

艺 苍

के

華

क ते

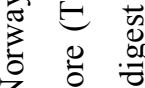

$z$ 品.

突范

त

on क

壱

की 3 竞

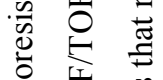

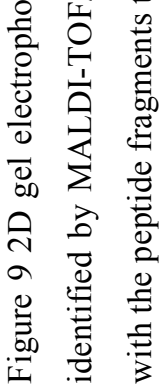




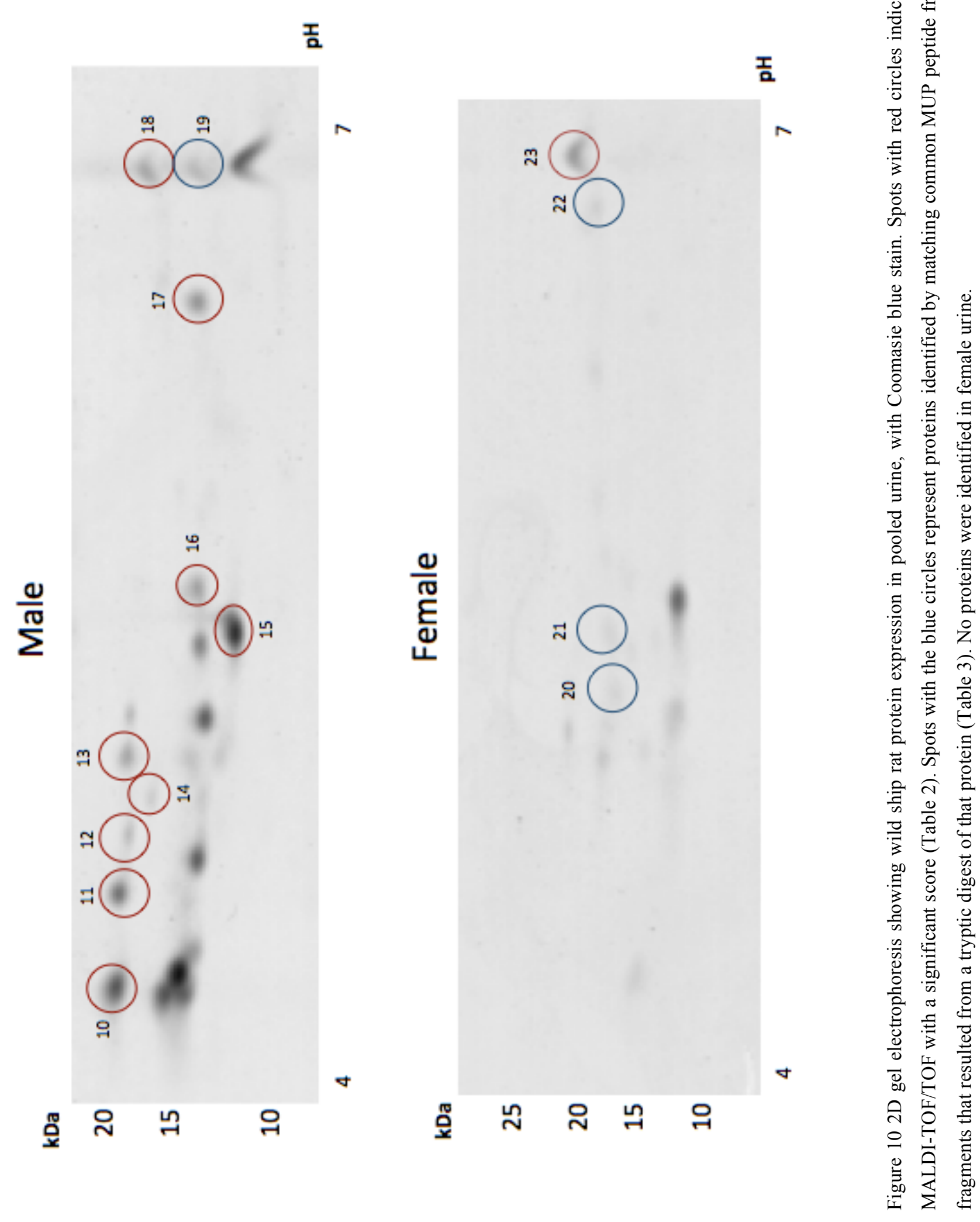




\begin{tabular}{|c|c|c|c|c|c|}
\hline Spot \# & Name & gi\# & $\begin{array}{r}\text { Calc. MW } \\
(\mathrm{kDa})\end{array}$ & Calc. pI & Score \\
\hline 1 & alpha-2u globulin PGCL4 (Rattus rattus) & gil7688046 & 20621 & 4.86 & 156 \\
\hline 2 & alpha-2u globulin PGCL4 (Rattus rattus) & gil 7688046 & 20621 & 4.86 & 165 \\
\hline 3 & alpha-2u globulin precursor, partial (Rattus rattus) & gil204261 & 20454 & 5.43 & 112 \\
\hline $\mathbf{s}$ & $\begin{array}{l}\text { alpha-2u globulin (L type) precursor (Rattus rattus) } \\
\text { alpha- } 2 \mathrm{u} \text { globulin precursor }\end{array}$ & $\begin{array}{r}\text { giI5 } 51011131 \\
\text { giI202610 }\end{array}$ & 21007 & 5.41 & 157 \\
\hline 8 & alpha-2u globulin precursor, partial (Rattus rattus) & gil204261 & 20454 & 5.43 & 76 \\
\hline 9 & alpha-2u globulin precursor, partial (Rattus rattus) & gil204261 & 20454 & 5.43 & 70 \\
\hline 10 & Urinary protein 2 & giI6226289 & 11630 & 7.53 & 124 \\
\hline 11 & Urinary protein 2 & gil6226289 & 11630 & 7.53 & 115 \\
\hline 12 & alpha-2u globulin PGCL4 (Rattus rattus) & gil 7688046 & 20621 & 4.86 & 128 \\
\hline 13 & Urinary protein 2 & giI 6226289 & 11630 & 7.53 & 90 \\
\hline 14 & alpha-2u globulin PGCL4 (Rattus rattus) & gil76880469 & 20621 & 4.86 & 73 \\
\hline 15 & Ig kappa chain $\mathrm{C}$ region, $\mathrm{B}$ allele & gill 25144 & 11765 & 4.97 & 142 \\
\hline 16 & Urinary protein 2 & giI6226289 & 11630 & 7.53 & 106 \\
\hline 17 & Urinary protein 2 & giI6226289 & 11630 & 7.53 & 91 \\
\hline 18 & alpha-2u globulin PGCL3 (Rattus rattus) & giI22219448 & 20923 & 6.43 & 186 \\
\hline 23 & Major urinary protein 5 (Rattus rattus) & giI 4267893 & 21084 & 5.97 & 102 \\
\hline
\end{tabular}

Table 2 Protein identifications made with significant matches from 2D gel electrophoresis of rat urine (Figures 3 and 4). MUPs were identified in the male laboratory Norway rat, and both sexes of wild ship rat. * Both database entries and their isoelectric point (pI) match the peptide fragments obtained for this spot. Gi number refers to a sequence identification number given by the NCBI database. 


\section{Spot number Identified peptides $(+/-0.03)$}

\begin{tabular}{ll}
\hline 4 & 1303.6980 \\
$\mathbf{6}$ & $931.4940,1208.5406,2121.0833,1303.6771$ \\
$\mathbf{7}$ & $998.5685,1303.7135$ \\
$\mathbf{* 1 9}$ & $1208.6094,1303.7482$ \\
$\mathbf{2 0}$ & $1208.5503,1303.6891$ \\
$\mathbf{2 1}$ & $1190.6245,1208.5504,1303.6754$ \\
$\mathbf{2 2}$ & $1190.6245,1208.5504,1303.6755$ \\
\hline
\end{tabular}

Table 3 MUPs identified based on expected peptide fragments. Identified peptides listed were matched with known MUP peptide fragments resulting from a theoretical trypsin digest, determined using Expasy PeptideMass (online tool). Peptides found that are within 0.03 Da of known peptides were accepted. * These peptides are $>0.03 \mathrm{Da}$ from the expected peptide, however so was the control trypsin peak indicating calibration was off for the whole spectra. Pink rows represent spots that were also identified by MASCOT search as MUPs with a non-significant score. 


\subsection{Production of a recombinant protein.}

\subsubsection{Production of Recombinant Norway rat MUP}

\subsubsection{Generation of a major urinary protein gene construct}

Based on protein sequence, a National Center for Biotechnology Information database (BLAST) search identified the major urinary protein 4 precursor (MUP4; accession number NP_942079.1), as the most similar rat MUP protein to that of Darcin which is a male-specific mouse MUP (Figure 11). RNA was extracted from the kidney and liver tissue from one laboratory Norway rat, converted to DNA and amplified by PCR using primers designed for MUP 4, then run on a 1.5\% Agarose gel (Figure 12). The DNA was extracted from the PCR gel, ligated with a pGEM®-T Easy vector and then transformed in DH5- $\alpha$ cells. The mini prep DNA extracted from these transformed cells was confirmed by sequencing to contain major urinary protein precursor, accession number NP_671747.1 (Figure 13). This mini prep DNA was digested with BamHI and HindIII restriction enzymes to confirm the presence of an insert of the correct size (Figure 14). Thereafter, the DNA was then extracted, ligated with both pET23b and pQE32 and transformed with DH5- $\alpha$ cells. To ensure the ligation was successful, a restriction digest was performed on the mini prep DNA (Figure 15). BL21 cells were transformed with a pET23 vector containing MUPP and then used for protein expression. 


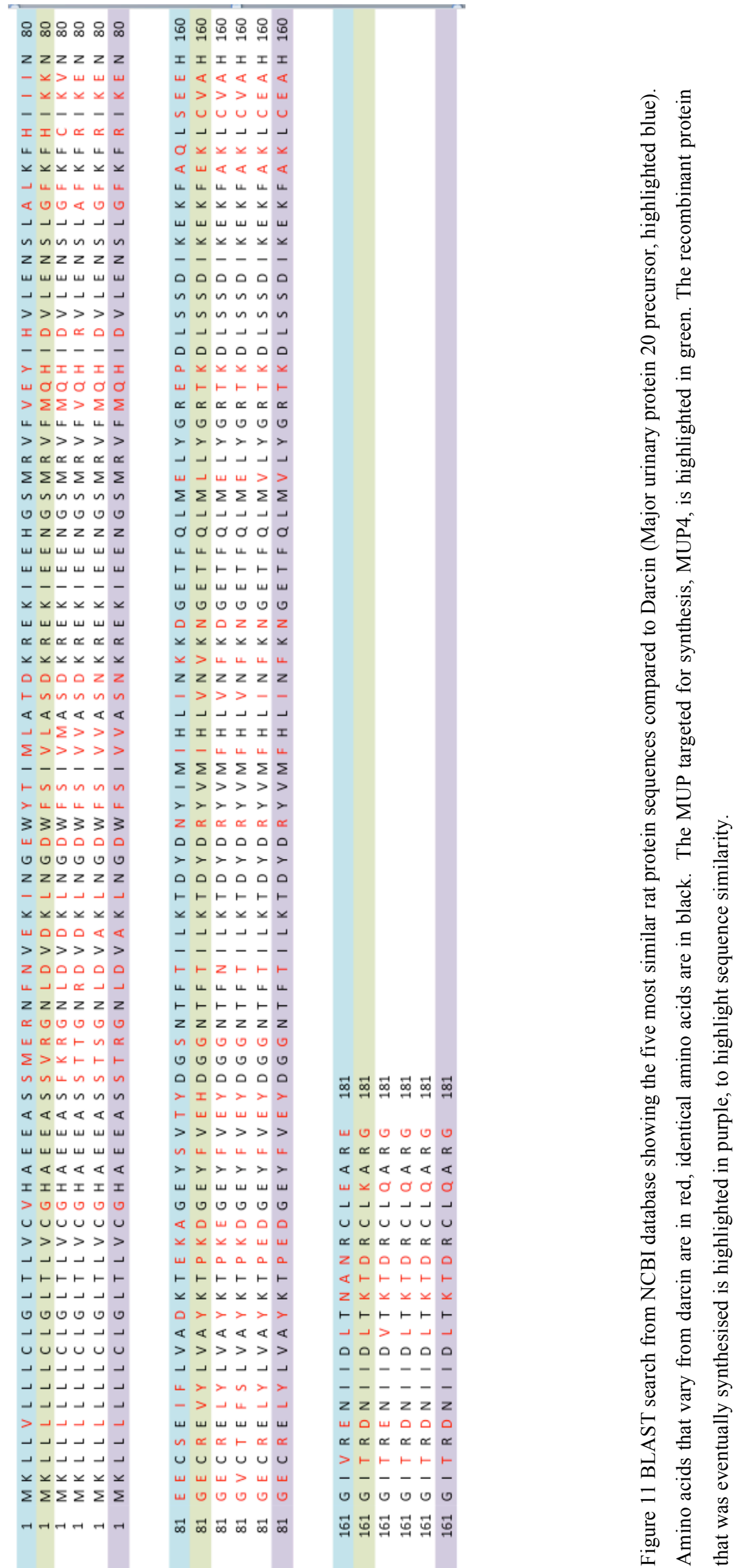

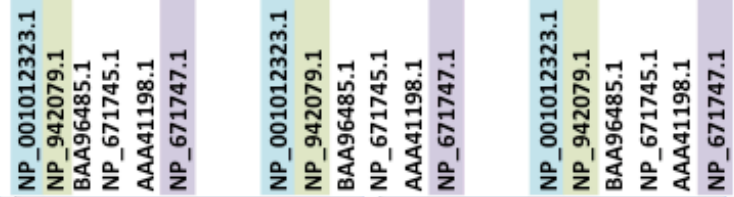




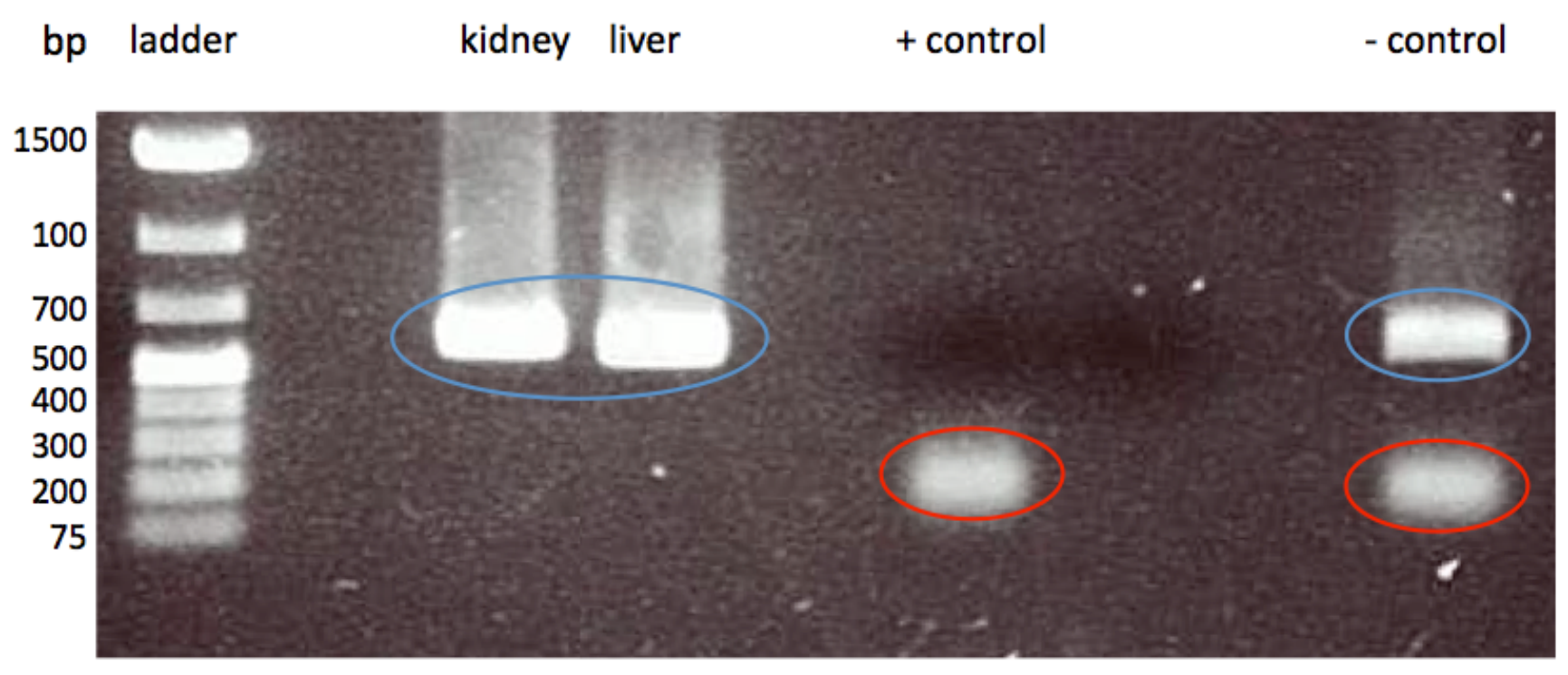

Figure 12 Generation of a MUP gene sequence by PCR. The cDNA from kidney and liver from a single male Norway rat was applified by PCR (blue circle). The negative control expressed MUP-sized cDNA (blue circle). Both the positive and negative controls expressed a non-specifc band (red circle), smaller than a MUP gene. 


\section{kidney}

pGEM $^{\circledR}-$ T Easy Vector

\section{MUP DNA}

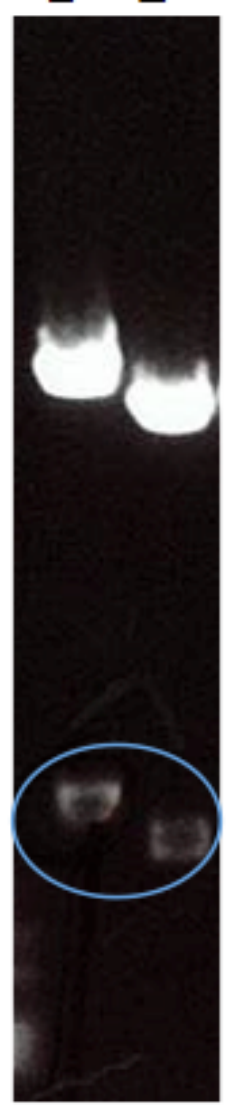

Figure 13 BamHI and HindIII digestion of DNA from DH5- $\alpha$ cells transformed with MUP in pGEM®-T Easy cloning vector. Two colonies of DH5- $\alpha$ cells had the DNA extracted and digested (kidney $1 \& 2$ ). MUP-sized bands were visualized (blue circle), and confirmed by DNA sequencing to be a MUP. 
GCTGTTGCTGCTGCTGCTGTGTCTGGGCCTGACACTGGTCTGTGGCCATGCAGAAGAAGC GCTGTTGCTGCTGCTGCTGTGTCTGGGCCTGACACTGGTCTGTGGCCATGCAGAAGAAGC TAGTTCCACAAGAGGGAACCTCGATGTGGCTAAGCTCAATGGGGACTGGTTTTCTATTGT TAGTTCCACAAGAGGGAACCTCGATGTGGCTAAGCTCAATGGGGATTGGTTTTCTATTGT CGTGGCCTCTAACAAAAGAGAGAAGATAGAAGAGAATGGCAGCATGAGAGTTTTTATGC CGTGGCCTCTAACAAAAGAGAAAAGATAGAAGAGAATGGCAGCATGAGAGTTTTTATGC AGCACATCGATGTCTTGGAGAATTCCTTAGGCTTCAAGTTCCGTATTAAGGAAAATGGA AGCACATCGATGTCTTGGAGAATTCCTTAGGCTTCAAGTTCCGTATTAAGGAAAATGGA GAGTGCAGGGAACTATATTTGGTTGCCTACAAAACGCCAGAGGATGGCGAATATTTTGT GAGTGCAGGGAACTATATTTGGTTGCCTACAAAACGCCAGAGGATGGCGAATATTTTGT TGAGTATGACGGAGGGAATACATTTACTATACTTAAGACAGACTATGACAGATATGTCA TGAGTATGACGGAGGGAATACATTTACTATACTTAAGACAGACTATGACAGATATGTCA TGTTTCATCTCATTAATTTCAAGAACGGGGAAACCTTCCAGCTGATGGTGCTCTACGGCA TGTTTCATCTCATTAATTTCAAGAACGGGGAAACCTTCCAGCTGATGGTGCTCTACGGCA GAACAAAGGATCTGAGTTCAGACATCAAGGAAAAGTTTGCAAAACTATGTGAGGCGCAT GAACAAAGGATCTGAGTTCAGACATCAAGGAAAAGTTTGCAAAACTATGTGAGGCGCAT GGAATCACTAGGGACAATATCATTGATCTAACCAAGACTGATCGCTGTCTCAAGGCCGA GGAATCACTAGGGACAATATCATTGATCTAACCAAGACTGATCGCTGTCTCCAGGCCCGA

GG

GG

Figure 14 Comparison of male laboratory Norway rat DNA (isolated from a kidney) with a rat MUP sequence, accession number NP_671747.1, from the NCBI database (black). Nucleotides shaded in pink represent where the sequences are different. Red nucleotides represent the primer region. The expect score of this alignment is 0 , and there are $99 \%$ identities. 


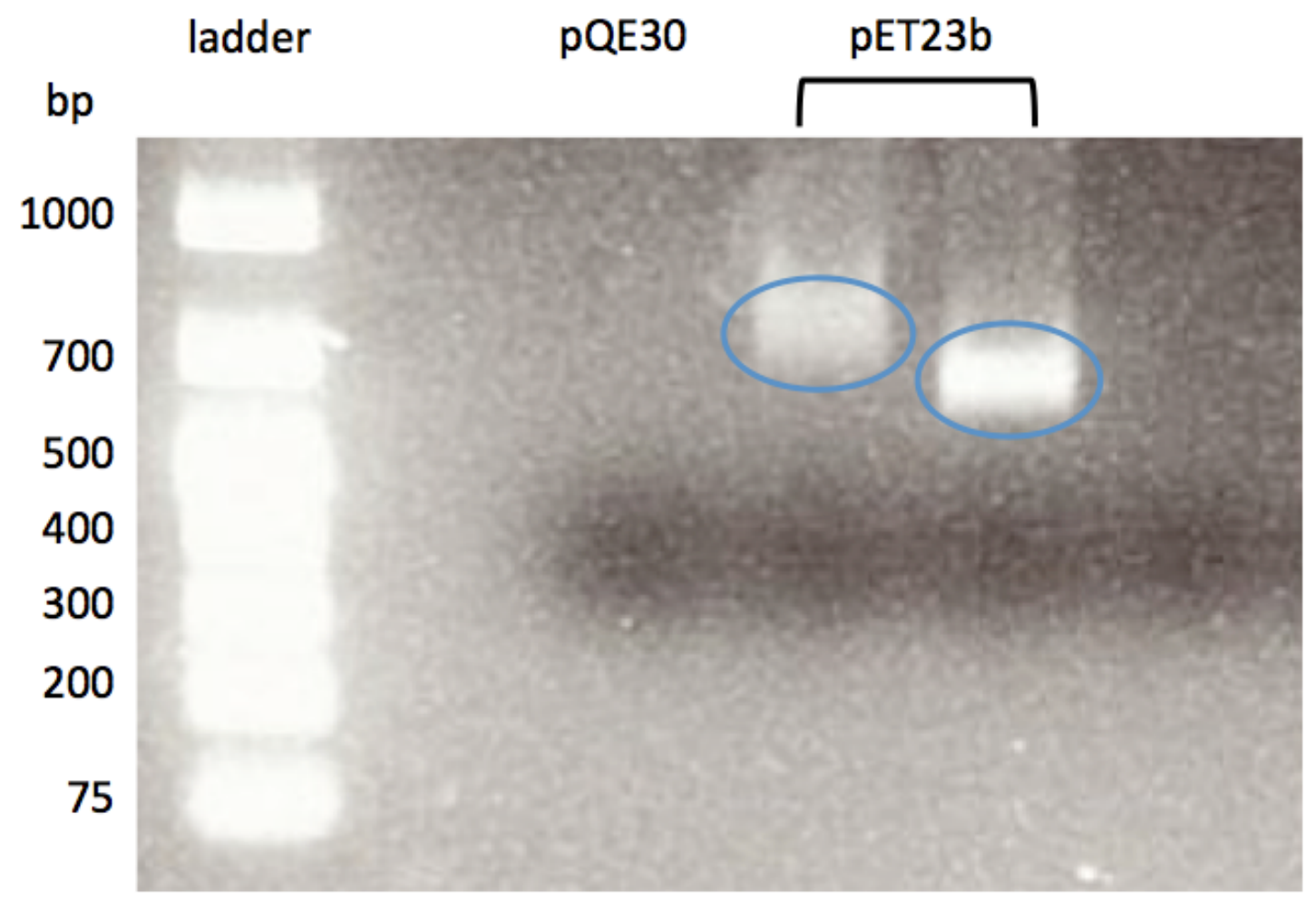

Figure 15 BamHI and HindIII digestion of DNA from DH5- $\alpha$ cells transformed with MUP in pET-23b and pEQ32 cloning vectors. MUP DNA can be seen between 700-500 bp (blue circles). Ligation with a pQE30 vector failed to ligate with this DNA, however two attempts at ligation with a pET23b vector were successful. Subsequently, the pET23b vector containing MUP DNA was able to be transformed with BL21 expressing cells. 


\subsubsection{Expression and purification of major urinary protein precursor (accession number, NP_671747.1) in E.coli}

MUP-sized proteins were present in the cell lysate of induced BL21(DE3)pLysS and identified in the inclusion bodies of these cells (Figure 16). The presence of the target MUP was confirmed by MALDI-TOF/TOF, with a significant score (results not shown). Rosetta 2(DE3)pLysS cells also expressed MUPs but these were retained in the inclusion bodies (Figure 17). However, extending the induction protocol of Rosetta 2(DE3)pLysS cells to 16 hours at $25^{\circ} \mathrm{C}$ enabled the MUP to enter the soluble fraction of the cell lysate (Figure 18). The presence of this protein was tentatively identified by MALDI-TOF/TOF (results not shown). However, an additional large-scale expression using this developed protocol confirmed the protein was soluble (Christine Stockum, personal communication). MUP was purified from both cells lines (Figure 19), however, more protein was purified from Rosetta cells compared with the BL21 cells, as determined by BCA (Figure 20). All attempts at dialysis resulted in the formation of precipitated protein. 

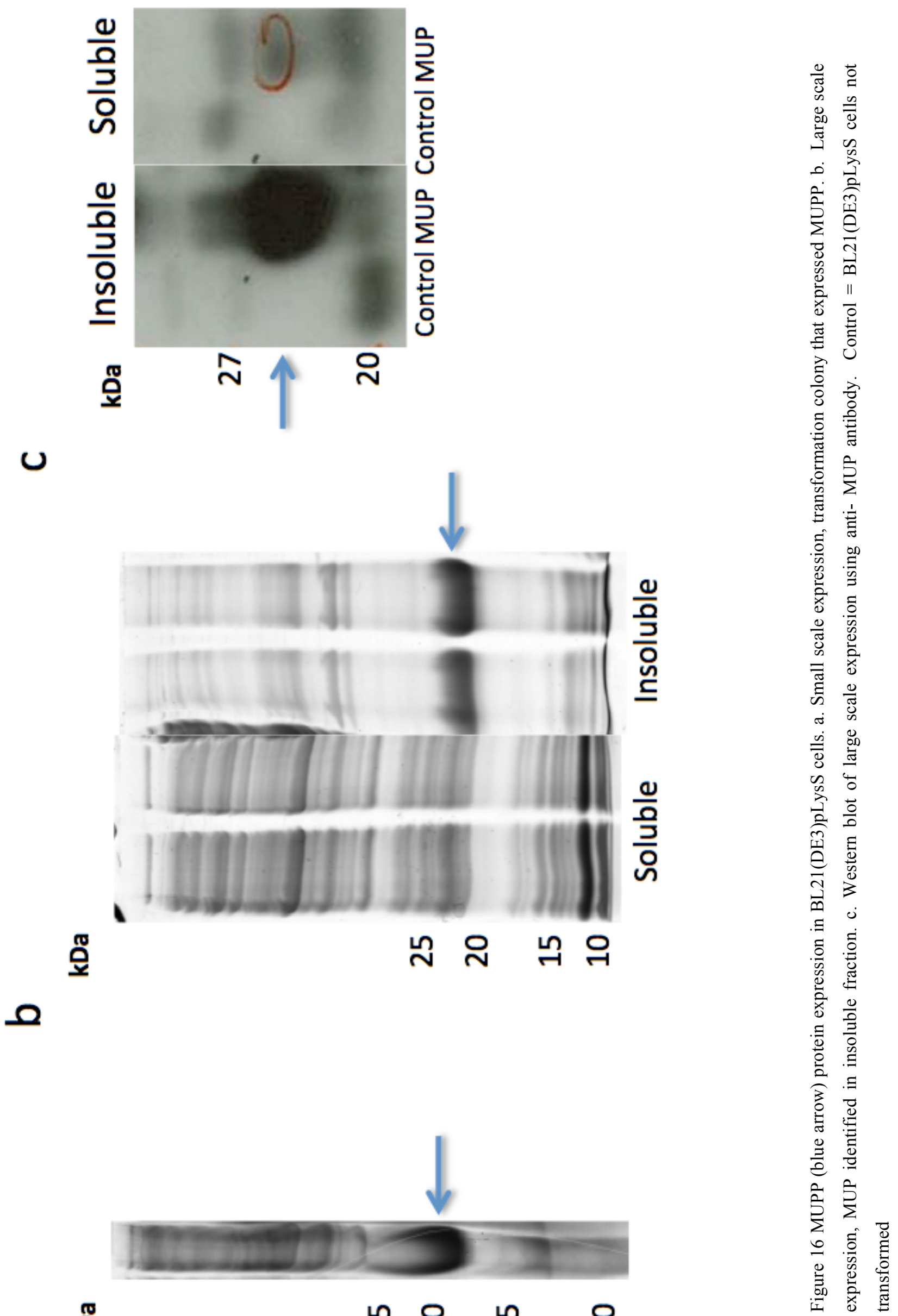

จ๊ำกำำ 


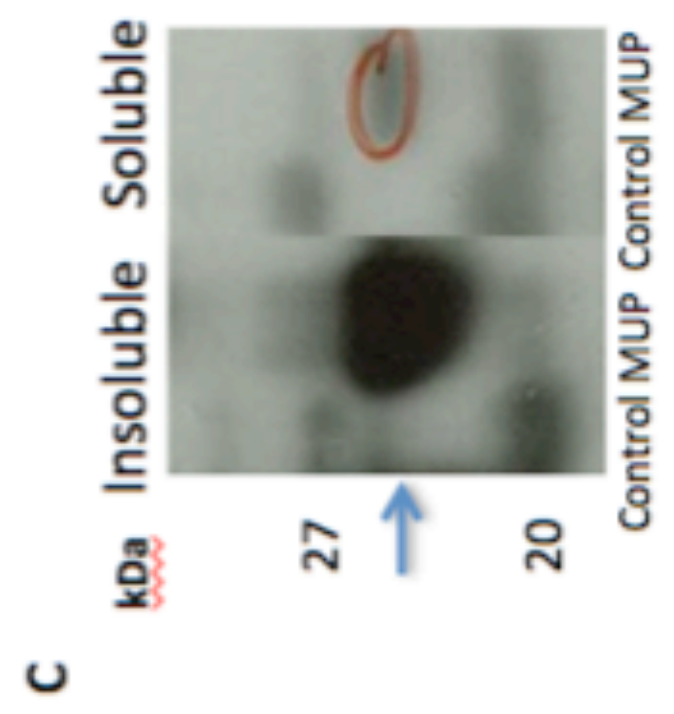

$$
\text { ฝำ 느ำㄱำ }
$$

m

$0 \stackrel{\frac{n}{5}}{\frac{0}{5}}$

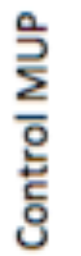

ตุ
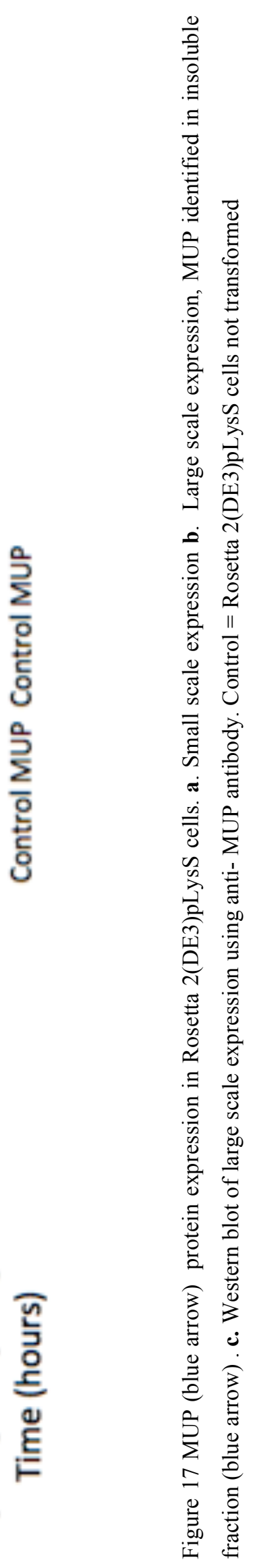


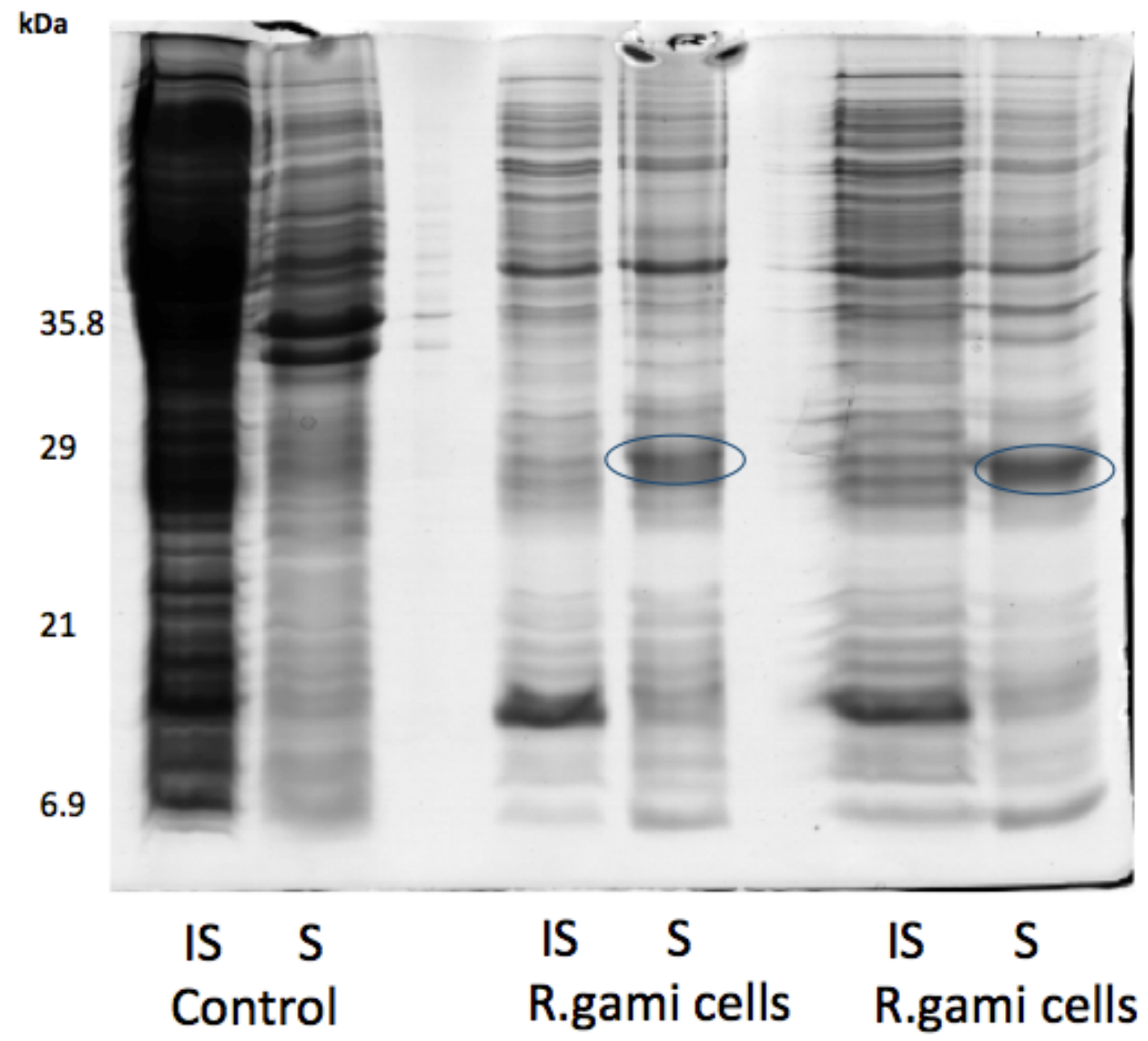

Figure 18 The major urinary protein precursor (accession number, NP_671747.1) was identified in the soluble fraction of Rosetta 2(DE3)pLysS cells (blue circle) induced with IPTG for 16 hours., ISinsoluble, S- soluble. The presence of this protein was confirmed by MALDI-TOF/TOF (results not shown . Control $=$ Rosetta 2(DE3)pLysS cells not transformed. 
a

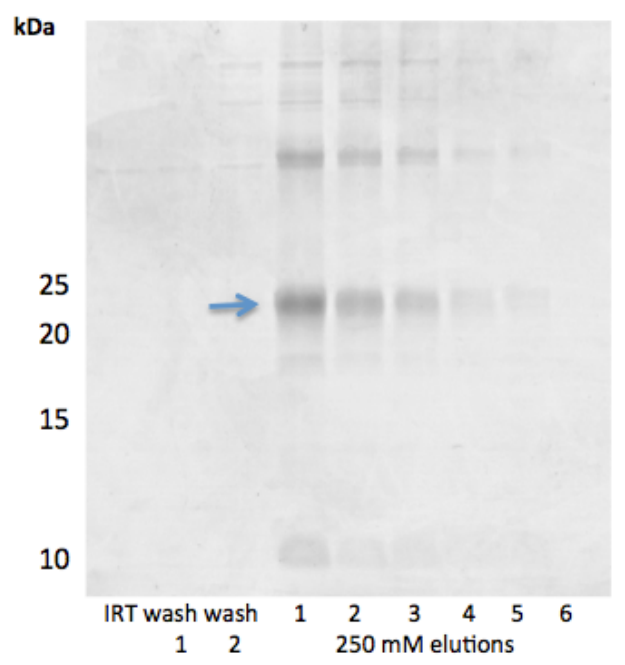

b

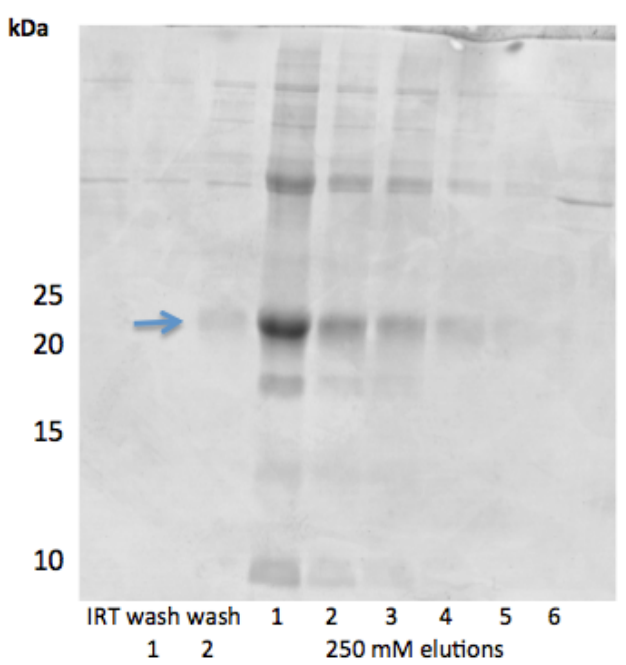

Figure 19 Purified major urinary protein precursor (accession number, NP_671747.1) (blue arrow) in BL21(DE3)pLysS (a) and Rosetta 2(DE3)pLysS (b) cells. IRT- initial run through. The MUP protein was displaced with $250 \mathrm{mM}$ imidazole, however some protein expressed in R.gammi cells was displaced in the $20 \mathrm{mM}$ imidazole wash (wash 2).

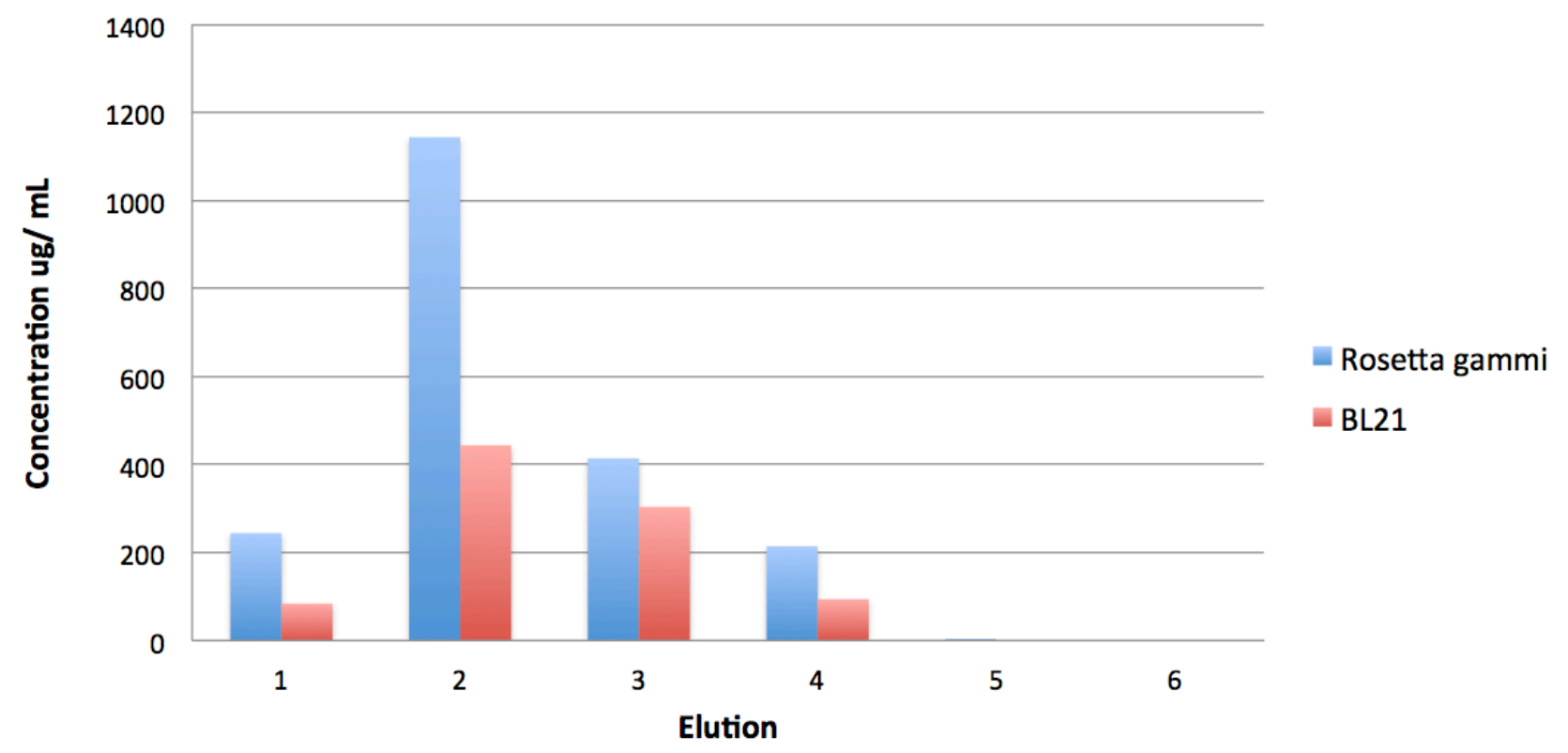

Figure 20 Comparisons of the purified protein concentrations from one large scale expression using Rosetta 2(DE3)pLysS (blue) and from BL21(DE3)pLysS (red) cells. In each elution, Rosetta cells expressed more protein than that by the BL21 cells, $2020 \mu \mathrm{g} / \mathrm{mL}$ compared with $926 \mu \mathrm{g} / \mathrm{mL}$, respectively. 


\subsection{Identification of MUP genes in wild rats}

To investigate the MUP genes present in female laboratory Norway rats, and both sexes of wild Norway and wild ship rats, RNA was extracted from the kidney and liver tissue of one female laboratory Norway rat, two male and two female wild ship rats, and one male and one female wild Norway rat. These were each converted to DNA and amplified by PCR using primers designed for MUP 4 and then run on a 1.5\% Agarose gel (Figure 21). The gene sequence for alpha-2u-globulin (accession \#: M26838.1) was found to have $99 \%$ identity compared with a gene sequence obtained from the identified in female laboratory Norway's rat liver tissue (Figure 22). The protein sequence derived from the nucleotide sequence was identified as alpha-2u-globulin PGCL2 precursor (accession \#: NP_988843.2) (Figure 23). Liver tissue from one male ship rat expressed a gene identified as alpha-2u-globulin (accession \#: J00738.1), which when translated was identified as alpha-2 $\mathrm{u}$ globulin protein (accession \#: AAA88508.1). At the nucleotide level there was 95\% identity (Figure 24), and 91\% identity at the protein level (Figure 25). The kidney tissue from one female ship rat expressed the same gene sequence as the female laboratory Norway rat (accession \#: M26838.1), and the translated protein sequence was identified as alpha-2u-globulin protein (accession \#: AAA40642.1) with 99\% identity at both nucleotide (Figure 26) and protein level (Figure 27). 

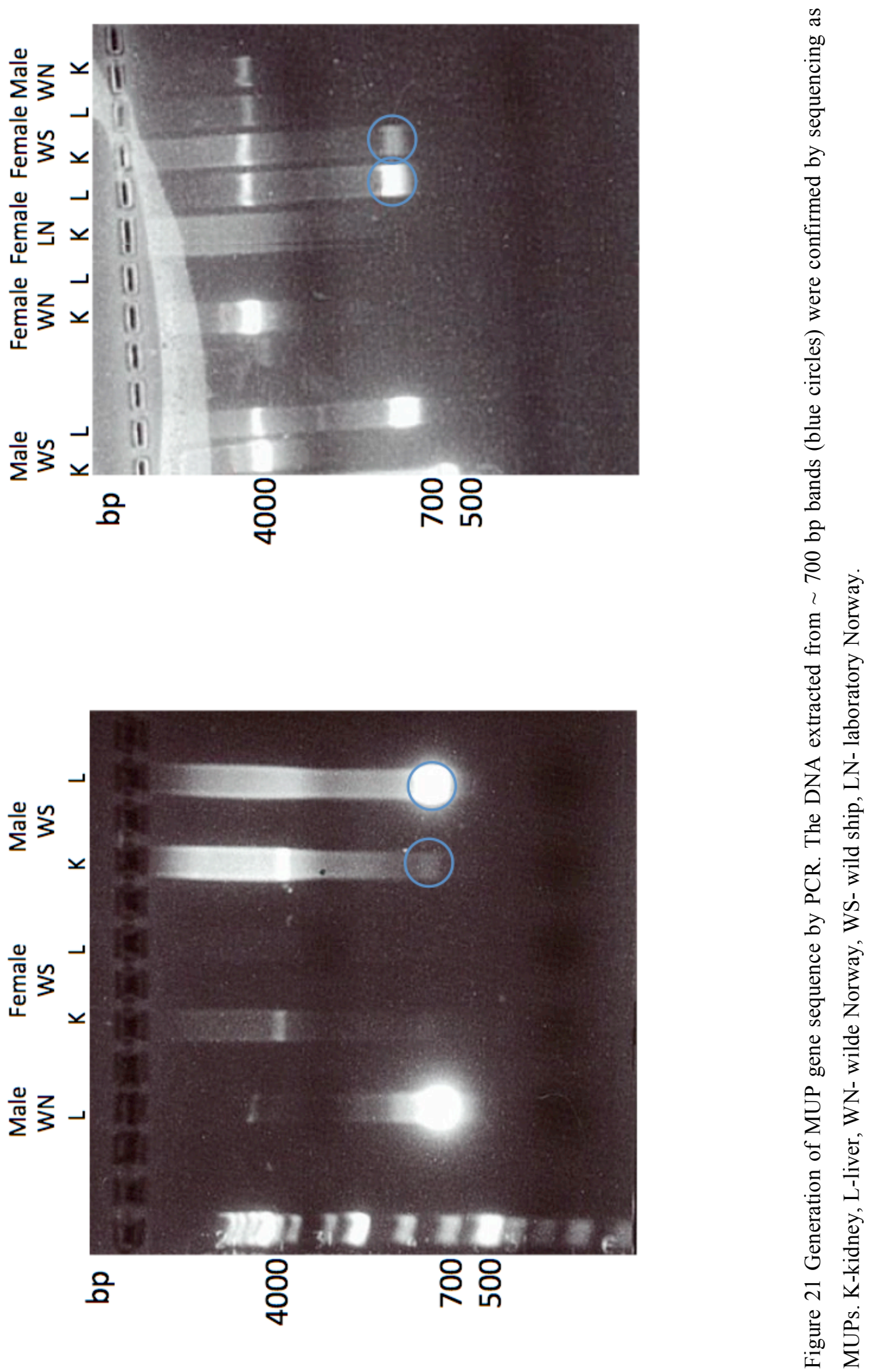
GCTGTTGCTGCTGCTGCTGTGTCTGGGCCTGACCCTGGTCTGTGGCCATGCGGAAGAAGC GCTGTTGCTGCTGCTGCTGTGTCTGGGCCTGACCCTGGTCTGTGGCCATGCAGAAGAAGC

TAGTTCCGAGAGAÄGGAACCTCGATGTGGACAAGCTCAATGGGGATTGGTTTTCTATTG TAGTTTCGAGAGAGGGAACCTCGATGTGGACAAGCTCAATGGGGATTGGTTTTCTATTG

GCĞTGGCCTCTGACAAAAGAGAAAAGATAGAAGAGAACGGCAGCATGAGAGTTTTTGTG TCG̈TGGCCTCTGATAAAAGAGAAAAGATAGAAGAGAACGGCAGCATGAGAGTTTTTGTG CAGCACATCGATGTCTTGGAGAATTCCTTAGGCTTCAÄGTTCCÄTATCAAGAAAAATGG CAGCACATCGATGTCTTGGAGAATTCCTTAGGCTTCACGTTCCGTATTAAGGAAAATGG AGTGTGCACAGAATTTTCTTTGGTTGCCTACAAAACGGCAAAGGATGGCGAATATTTTG AGTGTGCACAGAATTTTCTTTGGTTGCCĞACAAAACAGCAAAGGATGGCGAATATTTTG TTGAGTATGACGGAGAGAATACATTTACTATACTTGAGACAGACTATGACAATTATGTC TTGAGTATGACGGAGAAAATACATTTACTATACTGAAGACAGACTATGACAATTATGTC ATGATTCATCTCGTTAATGTCAAGAACGGGGAAACC̈TTCCAGTTGATGGAGCTCTACGGC ATGTTTCATCTCGTTAATGTCAACAACGGGGAAACÄTTCCAGC̈TGATGGAGCTCTACGGC AAAACAAAGGATCTGAGTTCAGACATCAAGGAAAAGTTTGCAGAACTATGTGÄGGCGCA AGAACAAAGGATCTGAGTTCAGACATCAAGGAAAAGTTTGCAAAACTATGTGTGGCACA TGGAATCACÄAGGGACAATG̈TCATTGACCTAACCAAGACTGATCGCTGTCTCCAGGCCCG TGGAATCACTAGGGACAATÄTCATTGACCTAACCAAGACTGATCGCTGTCTCCAGGCCCG

AGG

AGG

Figure 22 Comparison of DNA amplified from the liver tissue of one female laboratory Norway rat against known MUP nucleotide sequence, alpha-2u-globulin mRNA (accession \#: M26838.1). Expected score 0 , identity $99 \%$. The highlighted letters represent where the two sequences vary. 

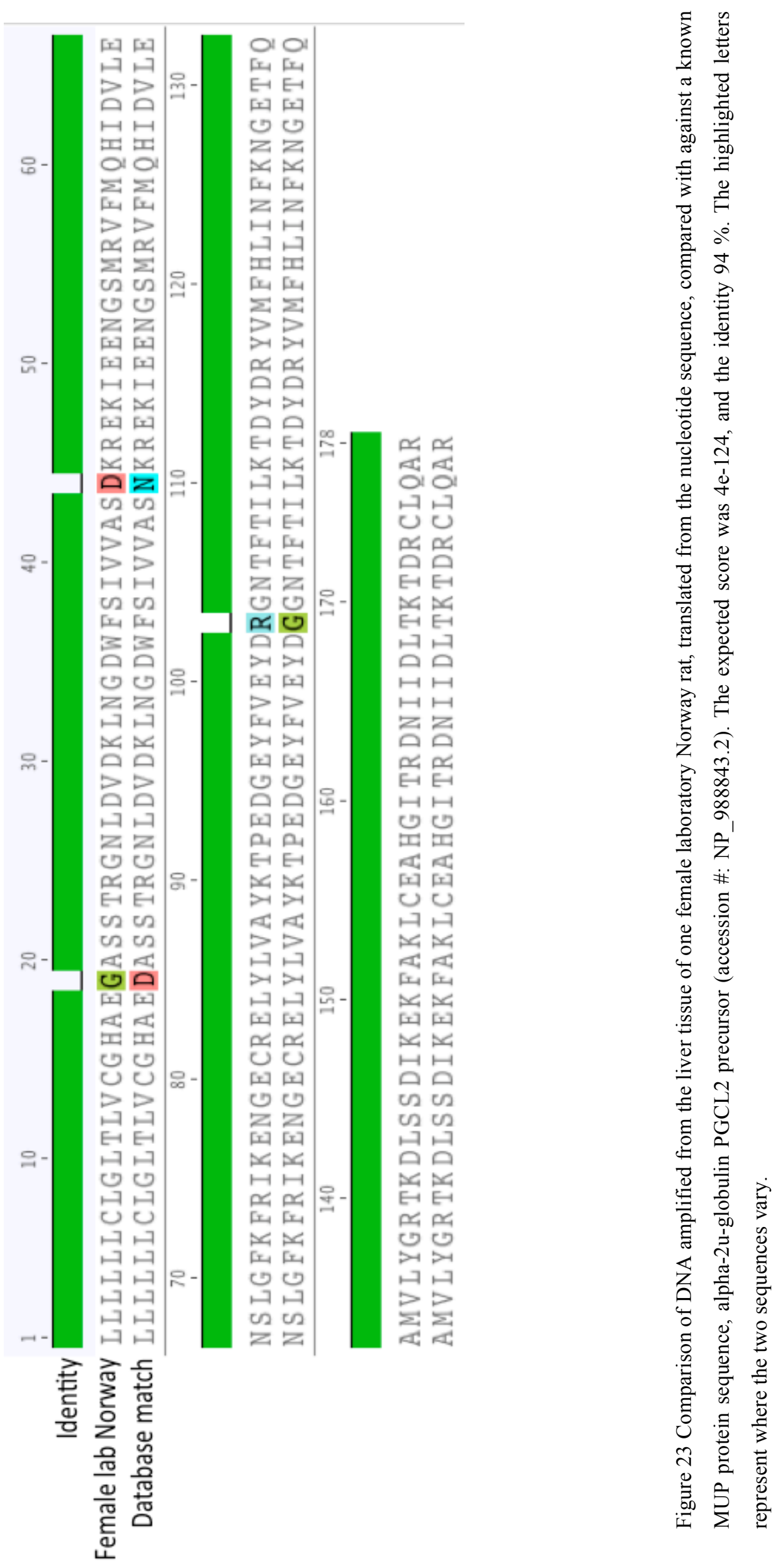
GCTGTTGCTGCTGCTGCTGTGTCTGGGCCTGACACTGGTCTGTGGCCATGCAGAAGGAGC GCTGTTGCTGCTGCTGCTGTGTCTGGGCCTGACACTGGTCTGTGGCCATGCAGAAGAAGC TAGTTCCACAAGAGGGAACCTCGATGTGGACAAGCTCAATGGGGATTGGTTTTCTATTG TAGTTCCACAAGAGGGAACCTCGATGTGGACAAGCTCAATGGGGATTGGTTTTCTATTG TCGTGGCCTCTGACAAAAGAGAAAAGATAGAAGAGAATGGCAGCATGAGAGTTTTTATG TCGTGGCCTCTGACAAAAGAGAAAAGATAGAAGAGAATGGCAGCATGAGAGTTTTTATG CAGCACATCGATGTCTTGGAGAATTCCTTAGGCTTCAAGTTCCGTATTAAGGAAAATGG CAGCACATCGATGTCTTGGAGAATTCCTTAGGCTTCAAGTTCCGTATTAAGGAAAATGG AGAGTGCAGGGAACTATATTTGGTTGCCTACAAAACGCCAGAGGATGGCGAATATTTTG AGAGTGCAGGGAACTATATTTGGTTGCCTACAAAACGCCAGAGGATGGCGAATATTTTG TTGAGTATGACAGAGGGAATACATTTACTATACTTAAGACAGACTATGACAGATATGTC TTGAGTATGACGGAGGGAATACATTTACTATACTTAAGACAGACTATGACAGATATGTC ATGTTTCATCTCATTAATTTCAAGAACGGGGAAACCTTCCAGGCGATGGTGCTCTACGGC ATGTTTCATCTCATTAATTTCAAGAACGGGGAAACCTTCCAGGCGATGGTGCTCTACGGC AGAACAAAGGATCTGAGTTCAGACATCAAGGAAAAGTTTGCAAAACTATGTGAGGCGCA AGAACAAAGGATCTGAGTTCAGACATCAAGGAAAAGTTTGCAAAACTATGTGAGGCGCA TGGAATCACTAGGGACAATATCATTGATCTAACCAAGACTGATCGCTGTCTCCAGGCCCG TGGAATCACTAGGGACAATATCATTGATCTAACCAAGACTGATCĀCTGTCTCCAGGCCCG

AGG

AGG

Figure 24 Comparison of DNA amplified from the liver tissue of one male ship rat against a known MUP nucleotide sequence of Rattus norvegicus submaxillary gland alpha-2u globulin mRNA (accession \#: J00738.1). Expected score 0, identity 95\%. The highlighted letters indicate where the two sequences vary. 


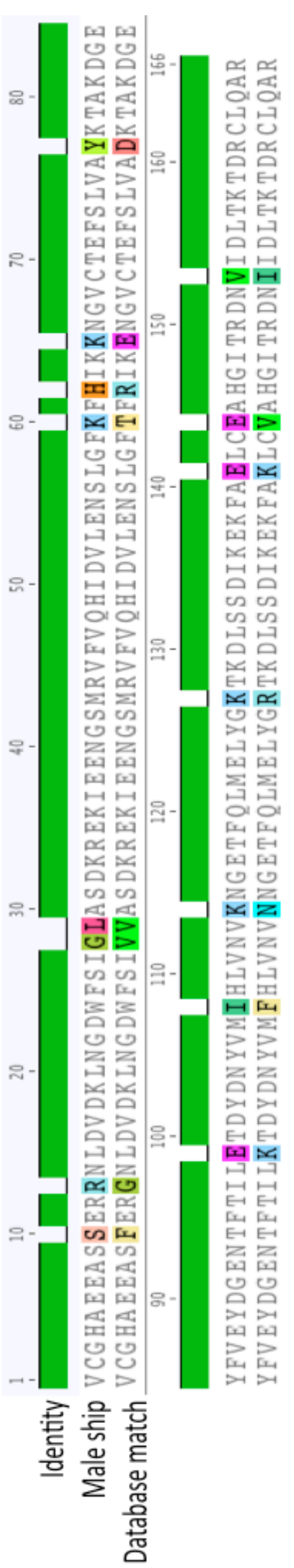

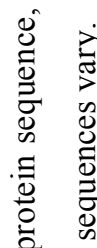

实主

产

\%

苛

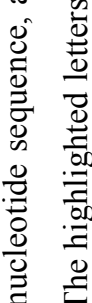

$\doteq 0^{\circ}$

ฮิ

$\Leftrightarrow$

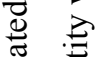

त्ञ

-

E

쿠

की

ฮั

ษ

4

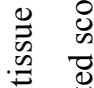

:

\&

$\pm$

宅

z

:

ह

$\overleftrightarrow{\sharp}$

ไ. 은

-

亏5

है :

훙

๙

奇 
GCTGTTGCTGCTGCTGCTGTGTCTGGGCCTGACACTGGTCTGTGGCCATGCAGAAGAAGC GCTGTTGCTGCTGCTGCTGTGTCTGGGCCTGACACTGGTCTGTGGCCATGCAGAAGAAGC

TAGTTCCACAAGAGGGAACCTCGATGTGGACAAGCTCAATGGGGACTGGTTTTCTATTGT TAGTTCCACAAGAGGGAACCTCGATGTGGCTAAGCTCAATGGGGATTGGTTTTCTATTGT CGTGGCCTCTGACAAAAGAGAAAAGATAGAAGAGAATGGCAGCATGAGAGTTTTTATGC CGTGGCCTCTÄACAAAAGAGAAAAGATAGAAGAGAATGGCAGCATGAGAGTTTTTATGC AGCACATCGATGTCTTGGAGAATTCCTTAGGCTTCAAGTTCCGTATTAAGGAAAATGGA AGCACATCGATGTCTTGGAGAATTCCTTAGGCTTCAAGTTCCGTATTAAGGAAAATGGA GAGTGCAGGGAACTATATTTGGTTGCCTACAAAACGCCAGAGGATGGCGAATATTTTGT GAGTGCAGGGAACTATATTTGGTTGCCTACAAAACGCCAGAGGATGGCGAATATTTTGT TGAGTATGACÄGAGGGAATACATTTACTATACTTAAGACAGACTATGACAGATATGTCA TGAGTATGACGGAGGGAATACATTTACTATACTTAAGACAGACTATGACAGATATGTCA TGTTTCATCTCATTAATTTCAAGAACGGGGAAACCTTCCAGGCGATGGTGCTCTACGGCA TGTTTCATCTCATTAATTTCAAGAACGGGGAAACCTTCCAGCTGATGGTGCTCTACGGCA GAACAAAGGATCTGAGTTCAGACATCAAGGAAAAGTTTGCAAAACTATGTGAGGCGCAT GAACAAAGGATCTGAGTTCAGACATCAAGGAAAAGTTTGCAAAACTATGTGAGGCGCAT GGAATCACTAGGGACAATATCATTGATCTAACCAAGACTGATCGCTGTCTCCAGGCCCGA GGAATCACTAGGGACAATATCATTGATCTAACCAAGACTGATCGCTGTCTCCAGGCCCGA GG GG

Figure 26 Comparison of DNA amplified from the liver tissue of one female ship rat against a known MUP nucleotide sequence, alpha-2u-globulin mRNA (accession \#: M26838.1). Expected score 0, identity $99 \%$. The highlighted letters indicate where the two sequences vary. 

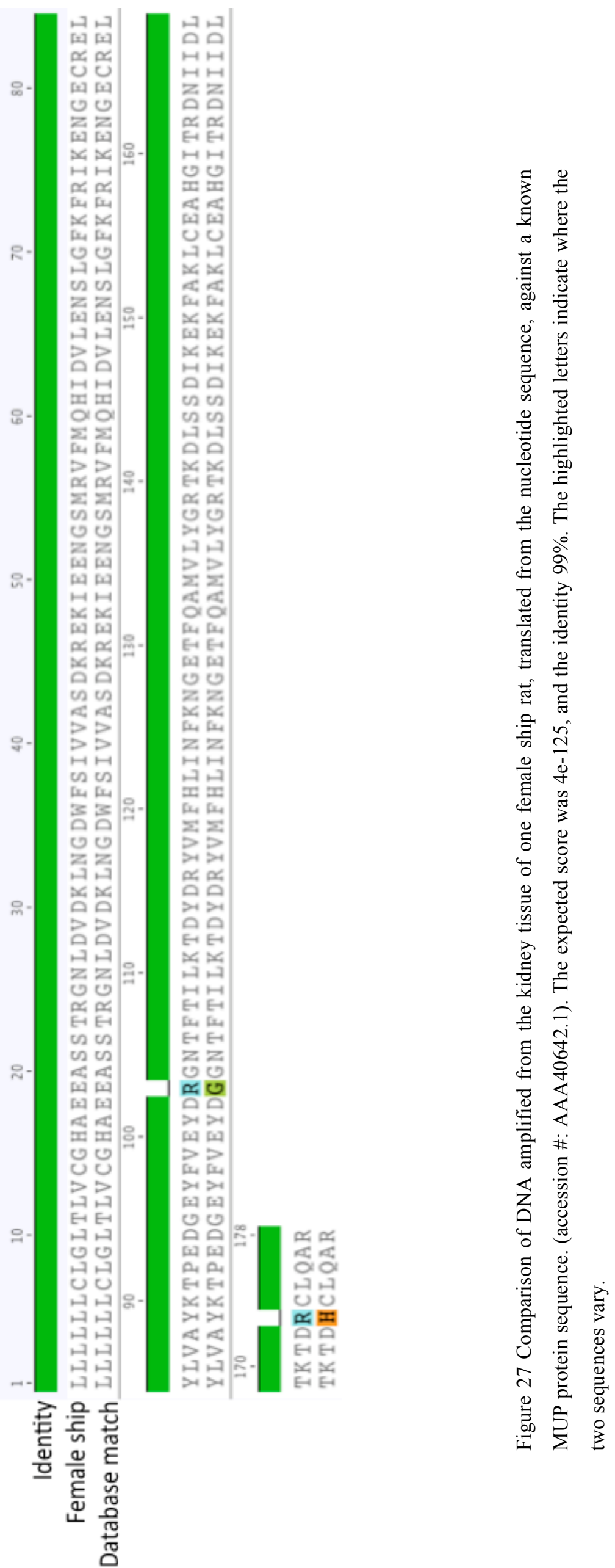


\section{Discussion}

The primary objective of this work was to identify and, if possible, produce a chemical attractant from male rats, which could be used to lure female conspecifics to a specific site. The purpose of this strategy is to aid detection and then to eliminate an invading population, especially when present at low numbers.

To achieve this objective, an analysis was undertaken of the volatile organic (pheromonal) attractants that were present in Norway and ship rat urine and to establish whether any of these were male specific. The technique used to investigate this was Gas Chromatography/ Mass Spectrometry (GC/MS). Male laboratory and wild Norway rat urine was found to contain four and six potentially specific volatile compounds respectively whereas male ship rats were found with one potential male specific compound. From the ship rats there were another six compounds where the concentrations were very low in females compared to those in the males. The compounds identified as potentially male specific in both sources of Norway rats did not appear to be the same, but this is probably a consequence of comparing unequal sample numbers since only one male and one female wild Norway rat were examined. Moreover, none of the aforementioned compounds were those previously reported to be present in urine from laboratory rats (Lehman-mckeeman et al., 1998; Zhang et al., 2007; Osada, Kashiwayanagi, \& Izumi, 2009). There appear to be very few reports describing the presence of volatile organic compounds in wild Norway or ship rats, with the one noted describing volatiles in Rattus rattus found in India having no similar compounds as identified in this study (Selvaraj \& Archunan, 2002). Of those volatiles recorded in the present study, only tentative identifications could be made for the majority, as only 4-heptanone was available to run as a reference standard. In addition, without knowledge of the concentrations in the urine samples and the small sample sizes it is not possible to conclude unequivocally that male-specific compounds were indeed present.

In the present study, the levels of 2-heptanone were consistently higher in males compared to females in both species and sources of rats: this is consistent with the work of Zhang et al (Zhang et al., 2008; Zhang \& Zhang, 2011) who identified these sex 
differences in three strains of laboratory Norway rat, including Sprague Dawley. These studies also showed that the levels of 2-heptanone were consistently higher than 4heptanone: this was confirmed from the findings of this study. However in the present study the presence of 4-heptanone was noted in the laboratory Norway females and this was not the case in the previously published studies (Zhang et al., 2008; Zhang \& Zhang, 2011), where no 4-heptanone was identified in three different strains of female laboratory Norway rat urine. The levels of both 2-heptanone and 4-heptanone have been shown to increase with sexual maturation in males (Osada et al., 2009). It has also been reported that the addition of these two compounds to the urine from males of the Brown Norway $(\mathrm{BN})$ rat strain to the levels found in the Lewis Norway (LN) rat strain, attracted female BN rats; whereas previously, probably due to avoid inbreeding, BN females had preferred LN male urine (Zhang \& Zhang, 2011). Additionally, when three volatile compounds, including 2-heptanone, 4-methylphenol, and 4-ethylphenol were added to prepubescent urine, at levels that matched those in mature males, the sexual attractiveness to females was further enhanced. These finding all suggest that 2heptanone and 4-heptanone together with or without additional volatiles may play a role in sexual attraction in laboratory Norway rats. In the present study, interpretation of the results needs to be treated with caution due to the lack of quantification and small sample size. To further investigate the potential of 2-heptanone and 4-heptanone as important pheromonal signaling molecules, a larger sample size would be needed for all rat groups, in addition to quantification of samples and confirmation of the identifications by running standards under the same protocol used for the urine sample analysis.

For volatile reagents to be released in a controlled manner, the expectation is that they would be associated with a MUP-like protein. From an analysis of rat urine from both species using one dimensional and two dimensional gel electrophoresis, in addition to MALDI-TOF/TOF, MUP-sized proteins (17-23 kDa) were identified. These were present in both male and female urine samples. Norway rats of laboratory origin had a relatively uniform expression pattern of MUP-sized proteins in both sexes, consistent with genetic inbreeding. The one male wild Norway rat that was analysed had a similar profile to laboratory male Norway rats. The wild Norway females had varied levels of protein expression, although without quantification of the total protein concentrations 
between the samples the biological relevance of this variability is unknown. In addition there was perhaps no surprise that for the wild ship rats there was also variable expression between the male and female individuals. The presence of MUP proteins was also confirmed by Western blotting, using a MUP-specific antibody. These results are consistent with the literature, describing the presence of MUPs in the urine of rats (Cavaggioni \& Mucignat-Caretta, 2000; Wait et al., 2001; Beynon \& Hurst, 2004;).

The two dimensional electrophoretic technique was used to identify the MUPs present in the urine of the laboratory Norway and wild ship rats. As the total protein levels were not known when the samples were loaded on the gels, the purpose of this study was simply to explore the number and diversity of MUPS that may have been present in the samples. MUPs were identified in all samples except in the urine of the female Norway rats similar to a previous report (Wait et al., 2001). However, the MUPs that were identified by Protein Pilot in the two dimensional gels didn't always match with the isoelectric point seen on the gel. The identifications were somewhat difficult as the matches were based on only a few peptide masses that were generally common in all the MUPs. In addition to matching the peptide masses, the Protein Pilot program provides the most significant score to the sequence with the most coverage, resulting in shorter, often precursor or incomplete sequences, being selected. Two other proteins, Ig kappa and rat urinary protein (RUP) were identified and their presence in rat urine is consistent with the literature (Wait et al., 2001). Therefore, although MUPs were identified in the urine of rats, the precise identification of those present was not determined.

As mentioned above the attempts to identify proteins in rat urine were sometimes unsuccessful, as the score given by protein pilot was not significant. Since some of these spots $(4,6,7,19,20,21,22$; see table 3$)$ did not have a high score match with protein pilot, individual spectra were then analysed and any peptide fragment that matched within +/- 0.03 Da of the predicted peptide masses was noted. If two or more fragments were matched then this was listed as a tentative identification. One exception to this was spot 4 (see table 3 ), which only had one peptide mass matched, however this was given a match to a MUP by protein pilot, even though the score was not significant so was included as a tentative identification. Many factors can compromise the ability to 
achieve a significant match; these may include an ineffective trypsin digest and lack of sample quantification to name just two of many limitations that result in only a limited number of peaks being seen in the spectra. Alternatively, the database might itself be limited by not containing the peptides that were being searched for; this would especially be the case for the ship rat proteins as there is only a partial MUP sequence available for this species, which was derived from the preputial gland of an Indian commensal rat (Rajkumar et al., 2010). This lack of ship rat sequence information was also a problem in identifying individual MUP proteins, as was noted when individual manually identified spectra contained peptides that were "unique" to multiple different database Norway proteins. This raises the possibility that wild ship rats excrete MUPs that differ to some extent from those in Norway rats.

Darcin is a male specific MUP found in mouse urine that has been shown to be sexually attractive to female mice. In addition female mice learn to associate the volatiles with the pheromone, allowing them to recognize that male when they later come across the same volatile profile. Also, a recombinant Darcin was attractive to female mice indicating that in-volatile proteins may also act as pheromones. In an attempt to create a rat MUP that may induce a response in females a construct was designed for transfection into $E$ coli. The most similar protein to mouse Darcin based on protein sequence was major urinary protein 4 (MUP4), found under accession number NP_942079, which had 69\% similarity. Forward and reverse primers were designed based on the MUP4 nucleotide sequence. However, these were not designed sufficiently to extract MUP4 as all 24 MUPs listed in the NCBI database have the same or very similar nucleotide sequences at both ends of the protein, making it difficult to extract one particular MUP. Although one base pair in the reverse primer sequence of MUP4 is unique, this still didn't result in its extraction. Instead a MUP, major urinary protein precursor (accession number NP_6714171.1) was extracted from laboratory Norway rat kidney tissue. A recombinant form of this MUP has been previously described as eliciting an avoidance response in mice (Papes, Logan, \& Stowers, 2010), which may indicate it's potential as being important in chemical communication. This MUP was successfully ligated into a pET23b vector, and transformed into BL21 E.coli cells. While the protein was initially produced in barely detectable levels, it was thought to be due to particular codons; TGT, GGA, CAT, CAA, TCT, AGA, TGA, TAA being 
important for MUP production, but not being used often by E.coli. However, this problem of low level expression was overcome with a re-ligation using the same vector and cell line. MUP was expressed by the BL21 cells in an insoluble form, indicating it was not folding correctly. Many attempts and different strategies were used to resolve this, however eventually a specific cell line, Rosetta-gami B(DE3)pLysS, enabled a solubilized form of the desired MUP to be secreted. This cell line provides rare tRNA's, including AGA, which is important for MUP production. Rosetta-gami $\mathrm{B}(\mathrm{DE} 3) \mathrm{pLysS}$ also aids in the formation of disulfide bonds which helps with protein folding (Tsumoto et al., 2003). These features may have helped with the solubility, though it is likely to be, at least in part, due to the extended induction protocol used.

An attempt to quantify the amount of purified protein indicated that the Rosetta cells produced a total of $2020 \mu \mathrm{g} / \mathrm{mL}$ of protein compared with the $926 \mu \mathrm{g} / \mathrm{mL}$ that the BL21 cells produced. These values are based one replicate of protein expression so cannot be confirmed; also some of the protein expressed by the Rosetta cells was washed off during the purification. It is also important to note that when performing a BCA assay to measure protein concentration, a maximum of $3 \mathrm{M}$ Urea is appropriate to use, whereas this study used samples with $8 \mathrm{M}$ urea to maintain the solubility of the sample, meaning accuracy may have been compromised. No measure of soluble MUP was done. In the Darcin study (Roberts et al., 2010), $10 \mu \mathrm{g}$ in $10 \mu \mathrm{L}$ was used to measure the response of mice, suggesting the amount of purified MUP produced in this study, per expression round, would be suitable for subsequent testing in behavioral studies.

Rat MUPs are glycosylated proteins whereas the product generated in the present study is not, given that it is produced by E.coli. Moreover, as soluble MUP has yet to be purified it is not known if the protein itself is folded inappropriately, which would render the material biologically inactive. Collectively, these may influence the ability of a volatile material to associate with the protein. Studies have shown that rats are attracted to, and can infer information from, conspecific urine, however exact components driving this are unknown (Lydell \& Doty, 1972; Hopp \& Timberlake, 1983). Laboratory and field-testing of the MUP with or without the volatiles using urine as a control will help to determine if there is any activity. If testing of the rat MUP proves to be negative and urine indicates a positive response then it is likely that the rat 
MUP may need to be produced in a mammalian cell line (293H). It is also possible that the MUP made is not a rat equivalent of Darcin, and basing the production of a rat MUP on the sequence similarity may be redundant. More information about the various Norway rat MUPs, and which are sex-specific would narrow down the search for an appropriate MUP for this purpose. Alternatively it may be more valuable to invest more time in investigating the volatiles that are sex-specific, as they will most likely elicit a response, and the MUPs can be used as a stabiliser and slow release mechanism.

While the production of a recombinant MUP from Norway rat tissue was useful for developing methodology, the species of interest is the ship rat. The aforementioned primer pairs were used to extract MUP RNA from the liver of wild ship rats of both sexes, and a female laboratory Norway rat. A MUP that had 95\% identities at mRNA level and $91 \%$ at protein level to a database Norway rat MUP, was sequenced from a wild male ship rat. Although similar, there are enough differences in these two sequences to suggest male ship rats have species specific MUPs. The females from both species had MUPs that were extremely close in both mRNA and protein sequence level, suggesting female ship rats may have similar MUPs to Norway rats. As the primers were able to detect multiple MUPs it is likely that there were multiple MUPs in each animal amplified with PCR and multiple transformations would need to be sequenced to determine how many different MUPs each species had, and also how different they were. In addition to this a greater sample size of each sex and species would be needed, especially for ship rats with the genetic diversity that exists between the animals. With this information we would be better suited to select a ship rat mRNA sequence on which to develop another recombinant MUP.

In summary the results of this study indicate that rats, like mice, contain volatile compounds and MUPS that may have the potential to act as chemical (pheromonal) attractants. Moreover, a recombinant MUP was produced in Norway rats that can now be tested to determine if it is likely to have a practical role as a chemical lure. The sequence information produced from wild ship rats will provide useful information to begin the development of a recombinant MUP specific for ship rats. Even if mammalian cell lines are needed in order to generate biologically active MUPS this approach still remains an achievable and practical goal. In conclusion, this study has provided 
preliminary information that will assist in developing a chemical lure to assist monitoring and eradication schemes. 


\section{References}

Apps, P. J. (2013). Are mammal olfactory signals hiding right under our noses? Naturwissenschaften, 100(6), 487-506.

Atkinson, I. A. E. (2006a). Introduced Mammals in a New Environment. Ecological studies, 186.

Atkinson, I. A. E. (2006b). Introduced Mammals in a New Environment. Biological Invasions in New Zealand, 186, 49-66.

Atkinson, I. a. E., \& Towns, D. R. (2001). Advances in New Zealand mammalogy 1990-2000: Pacific rat. Journal of the Royal Society of New Zealand, 31(1), 99109.

Atkinson, U. A. E. (1973). Spread of the ship rat (Rattus r. rattus L.) III New Zealand. Journal of the Royal Society of New Zealand, 3(3), 457-472.

Beynon, R. J., \& Hurst, J. L. (2004). Urinary proteins and the modulation of chemical scents in mice and rats. Peptides, 25(9), 1553-63.

Beynon, R. J., Veggerby, C., Payne, C. E., Robertson, D. H. L., Gaskell, S. J., Humphries, R. E., \& Hurst, J. L. (2002). Polymorphism in major urinary proteins: molecular heterogeneity in a wild mouse population. Journal of chemical ecology, 28(7), 1429-46.

Carter, C. (2006). The value of conservation What does conservation contribute to the economy? Retrieved from http://www.doc.govt.nz/documents/conservation/valueof-conservation.pdf

Cavaggioni, A., \& Mucignat-Caretta, C. (2000). Major urinary proteins, $\alpha 2$ U-globulins and aphrodisin. Biochimica et Biophysica Acta (BBA) - Protein Structure and Molecular Enzymology, 1482(1-2), 218-228.

Clapperton, B. K. (2006). A review of the current knowledge of rodent behaviour in relation to control devices. Science for Conservation, 263, 55. 
Coleman, J. D., \& Cooke, M. M. (2001). Mycobacterium bovis infection in wildlife in New Zealand. Tuberculosis (Edinburgh, Scotland), 81(3), 191-202.

Cowan, David P., Roger J. Quy, and Lambert, Mark. S. (2003). Ecological perspectives on the management of commensal rodents. ACIAR Monograph series, 96, 433439.

Darwish Marie, A., Veggerby, C., Robertson, D. H. L., Gaskell, S. J., Hubbard, S. J., Martinsen, L., ... Beynon, R. J. (2001). Effect of polymorphisms on ligand binding by mouse major urinary proteins. Protein Science, 10(2), 411-417.

Dilks, P., \& Towns, D. (2002). Developing tools to detect and respond to rodent invasions of islands : workshop report and recommendations. DOC science internal series, 59.

Dowding, J. E., \& Murphy, E. C. (1994). Ecology of ship rats (rattus rattus) in a kauri (agathis australis) forest in northland, New Zealand Journal of Ecology, 18(1972), $19-27$.

Drickamer, L. C. (1997). Responses to Odors of Dominant and Subordinate House Mice (Mus domesticus) in Live Traps and Responses to Odors in Live Traps by Dominant and Subordinate Males. Journal of Chemical Ecology, 23(11), 24932506.

Duncan, R., Matthai, R., Huppi, K., Roderick, T., \& Potter, M. (1988). Genes that modify expression of major urinary proteins in mice. Molecular and cellular biology, 8(7), 2705-12.

Flower, D. R. (1996). The lipocalin protein family: structure and function. The Biochemical journal, 318 (1), 1-14.

Goodwin, T. E., Eggert, M. S., House, S. J., Weddell, M. E., Schulte, B. a, \& Rasmussen, L. E. L. (2006). Insect pheromones and precursors in female African elephant urine. Journal of chemical ecology, 32(8), 1849-53. 
Green, W., \& Clarkson, B. (2006). Review of the New Zealand biodiversity strategy themes. Retrieved from http://doc.govt.nz/documents/conservation/nz-biodiversitystrategy-themes.pdf

Hastie, N. D., Held, W. A., \& Toole, J. J. (1979). Multiple genes coding for the androgen-regulated major urinary proteins of the mouse. Cell, 17(2), 449-457.

Held, W. a, \& Gallagher, J. F. (1985). Rat alpha 2u-globulin mRNA expression in the preputial gland. Biochemical genetics, 23(3-4), 281-90.

Hopp, S. L., \& Timberlake, W. (1983). Odor cue determinants of urine marking in male rats (Rattus norvegicus). Behavioral and neural biology, 37(1), 162-72.

Humphries, R. E., Robertson, D. H. L., Beynon, R. J., \& Hurst, J. L. (1999).

Unravelling the chemical basis of competitive scent marking in house mice. Animal Behaviour, 58(6), 1177-1190.

Innes, J. (2001). Advances in New Zealand mammalogy 1990-2000: European rats. Journal of the Royal Society of New Zealand, 31(1), 111-125. d

Innes, J. G. (1990). The handbook of New Zealand mammals. (C. M. King, Ed.) (pp. 206-225). Auckland, New Zealand: Oxford University Press.

J.O. Bishop, A.J. Clark, P.M. Clissold, S. Hainey, and U. F. (1982). Two main groups of mouse major urinary protein genes, both largely located on chromosome 4 . The EMBO Journal, 1(5), 615-620.

Jansen, P. (2011). The Goodnature ${ }^{\circledR}$ A24 automatic rat \& stoat Kill Trap Evaluation of Humaneness. Retrieved from http://goodnature.co.nz/img/Goodnature A24 Rat NAWAC.pdf

Jemiolo, B., Xie, T.-M., \& Novotny, M. (1991). Socio-sexual olfactory preference in female mice: Attractiveness of synthetic chemosignals. Physiology \& Behavior, 50(6), 1119-1122. d

Karlson, P., \& Luscher, M. (1959). Pheromones': a new term for a class of biologically active substances. Nature, 183(4653), 55-56. 
Krauter, K., Leinwand, L., D’Eustachio, P., Ruddle, F., \& Darnell, J. E. (1982).

Structural genes of the mouse major urinary protein are on chromosome 4 . The Journal of Cell Biology, 94 (2 ), 414-417.

Kumar, M., Roy, A. K., Axelrod, A. E. (1969). Androgenic Induction of [alpha]2uGlobulin in the Rat: Requirement of an Intact Pituitary. Nature, 223(5204), 399400.

Kurtz, D. T. (1981). Rat alpha $2 \mathrm{u}$ globulin is encoded by a multigene family. Journal of molecular and applied genetics, 1(1), 29-38.

Leal, W. S. (2013). Odorant Reception in Insects: Roles of Receptors, Binding Proteins, and Degrading Enzymes. Annual Review of Entomology, 58(1), 373-391.

Lehman-mckeeman, L. D., Caudill, D., Rodriguez, P. A., Eddy, C., Lehman-mckeeman, R., \& Pharmacol, C. A. T. A. (1998). 2-sec-butyl-4, 5-Dihydrothiazole Is a Ligand for Mouse Urinary Protein and Rat 2u-Globulin : Physiological and Toxicological Relevance. Toxicology and Applied Pharmacology, 40, 32-40.

Logan, D. W., Marton, T. F., \& Stowers, L. (2008). Species specificity in major urinary proteins by parallel evolution. PloS one, 3(9), e3280.

Lydell, K., \& Doty, R. L. (1972). Male rat of odor preferences for female urine as a function of sexual experience, urine age, and urine source. Hormones and behavior, 3(3), 205-12.

Novotny, M, Harvey, S., \& Jemiolo, B. (1990). Chemistry of male dominance in the house mouse, Mus domesticus. Experiemtia, 46, 109-113.

Novotny, M, Harvey, S., Jemiolo, B., \& Alberts, J. (1985). Synthetic pheromones that promote inter-male aggression in mice. Proceedings of the National Academy of Sciences, 82 (7), 2059-2061.

Novotny, M, Jemiolo, B., Harvey, S., Wiesler, D., \& Marchlewska-Koj, A. (1986).

Adrenal-mediated endogenous metabolites inhibit puberty in female mice. Science, $231(4739), 722-725$. 
Novotny, M. V. (2003). Pheromones, binding proteins and receptor responses in rodents. Biochemical society transactions, 31, 117-122.

Novotny, M V, Ma, W., Wiesler, D., \& Žídek, L. (1999). Positive identification of the puberty-accelerating pheromone of the house mouse: The volatile ligands associating with the major urinary protein. Proceedings of the Royal Society B: Biological Sciences, 266(1432), 2017-2022.

Novotny, Milos V, Jemiolo, B., Wiesler, D., Ma, W., Harvey, S., Xu, F., ... Carmack, M. (1999). A unique urinary constituent, 6-hydroxy-6-methyl-3-heptanone, is a pheromone that accelerates puberty in female mice. Chemistry \& Biology, 6(6), $377-383$.

Osada, K., Kashiwayanagi, M., \& Izumi, H. (2009). Profiles of volatiles in male rat urine: the effect of puberty on the female attraction. Chemical senses, 34(8), 71321.

Papes, F., Logan, D. W., \& Stowers, L. (2010). The vomeronasal organ mediates interspecies defensive behaviors through detection of protein pheromone homologs. Cell, 141(4), 692-703.

Parkes, J., \& Murphy, E. (2003). Management of introduced mammals in New Zealand. New Zealand Journal of Zoology, 30(4), 335-359.

Rajkumar, R., Ilayaraja, R., Liao, C., Archunan, G., Achiraman, S., Prakash, S., Tsay, Y. G. (2010). Detection of a $2 u$-globulin and its bound putative pheromones in the preputial gland of the Indian commensal rat (Rattus rattus) using mass spectrometry. Rapid Communications in Mass Spectometry, 24, 721-728.

Rekwot, P. I., Ogwu, D., Oyedipe, E. O., \& Sekoni, V. O. (2001). The role of pheromones and biostimulation in animal reproduction. Animal reproduction science, 65(3-4), 157-170.

Roberts, S. a, Simpson, D. M., Armstrong, S. D., Davidson, A. J., Robertson, D. H., McLean, L., Hurst, J. L. (2010). Darcin: a male pheromone that stimulates female memory and sexual attraction to an individual male's odour. BMC biology, 8, 75 . 
Rosevear, M., \& Urlich, D. (2010). Bovine Tb Strategy Review of Costs (pp. 1-85). Retrieved from http://www.biosecurity.govt.nz/files/pests/bovine-tb/tb-strategycost-review.pdf

Roy, A. K., Neuhaus, O. W., \& Harmison, C. R. (1966). Preparation and characterization of a sex-dependent rat urinary protein. Biochimica et Biophysica Acta (BBA) - General Subjects, 127(1), 72-81.

Roy, A. K., Otto, W. N. (1967). Androgenic Control of a Sex-dependent Protein in the Rat. Nature, 214, 618-620.

Russell, J. C., Towns, D. R., \& Clout, M. N. (2008). Review of rat invasion biology. Science for Conservation, 268, 53. Retrieved from http://www.doc.org.nz/upload/documents/science-and-technical/sfc286.pdf

Sax, D. F., Gaines, S. D., \& Brown, J. H. (2002). Species invasions exceed extinctions on islands worldwide: a comparative study of plants and birds. The American naturalist, 160(6), 766-83.

Selvaraj, R., \& Archunan, G. (2002). Chemical Identification and Bioactivity of Rat (Rattus rattus) Urinary Compounds. Zoological Studies, 41(2), 127-135.

Sharrow, S. D., Vaughn, J. L., Zídek, L., Novotny, M. V, \& Stone, M. J. (2002). Pheromone binding by polymorphic mouse major urinary proteins. Protein science : a publication of the Protein Society, 11(9), 2247-56.

Sippel, A. E., Kurtz, D. T., Morris, H. P., \& Feigelson, P. (1976). Comparison of in Vivo Translation Rates and Messenger RNA Levels of $\alpha$ 2U-Globulin in Rat Liver and Morris Hepatoma 5123D. Cancer Research, 36, 3588-3593.

Sokolowski, K., \& Corbin, J. G. (2012). Wired for behavior: from development to function of innate limbic system circuitry. Frontiers in Molecular Neuroscience, 5 .

Spurr, E. B., O’Connor, C. E., Morriss, G. A., Turner, J., \& Connor, C. E. O. (2006). Bait station preferences of Norway rats. DoC Research \& Development Series 255. 
Spurr, E., Morriss, G., Turner, J., O’Connor, C., \& Fisher, P. (2007). Bait station preferences of ship rats. Retrieved from http://csl.doc.govt.nz/Documents/scienceand-technical/DRDS271.pdf

Suckow, M. A., Weisbroth, S. H., \& Franklin, C. L. (2006). The Laboratory Rat. West Lafayette, IN: Academic Press.

Tsumoto, K., Ejima, D., Kumagai, I., \& Arakawa, T. (2003). Practical considerations in refolding proteins from inclusion bodies. Protein Expression and Purification, $28(1), 1-8$.

Van Zutphen, L. F., Lagerwerf, a, Bouw, J., \& den Bieman, M. G. (1981). Biochemical polymorphism in the rat: genetics of three electrophoretic variants and characterization of inbred strains. Biochemical genetics, 19(1-2), 173-86.

Wait, R., Gianazza, E., Eberini, I., Sironi, L., Dunn, M. J., Gemeiner, M., \& Miller, I. (2001). Proteins of rat serum, urine, and cerebrospinal fluid: VI. Further protein identifications and interstrain comparison. Electrophoresis, 22(14), 3043-52.

Watson, J.S. (1956). The present distribution of Rattus exulans (Peale) in New Zealand. New Zealand journal of science and tecnology, 37, 560.

Williams J.M (1973). The ecology of Rattus exulans (Peale) reviewed. Pacific Science, $27(2), 120-127$.

Witzgall, P., Kirsch, P., \& Cork, A. (2010). Sex Pheromones and Their Impact on Pest Management. Journal of Chemical Ecology, 36(1), 80-100.

Zhang, J.-X., Sun, L., Zhang, J.-H., \& Feng, Z.-Y. (2008). Sex- and gonad-affecting scent compounds and 3 male pheromones in the rat. Chemical senses, 33(7), 61121.

Zhang, Q., Wang, G., Du, Y., Zhu, L., \& Jiye, a. (2007). GC/MS analysis of the rat urine for metabonomic research. Journal of chromatography. B, Analytical technologies in the biomedical and life sciences, 854(1-2), 20-5. 
Zhang, Y.-H., \& Zhang, J.-X. (2011). Urine-derived key volatiles may signal genetic relatedness in male rats. Chemical senses, 36(2), 125-35. 